2011-8

\title{
Enhancing the Performance of Building Integrated Photovoltaics
}

\author{
Brian Norton \\ Technological University Dublin, brian.norton@tudublin.ie \\ Philip C. Eames \\ University of Loughborough \\ Tapas K. Mallick \\ Heriot-Watt University
}

See next page for additional authors

Follow this and additional works at: https://arrow.tudublin.ie/dubenart

Part of the Power and Energy Commons

\section{Recommended Citation}

Norton, B., et al (2011). Enhancing the performance of building integrated photovoltaics. Solar Energy, vol. 85, no. 8, pp. 1629-1664. doi:10.1016/j.solener.2009.10.004

This Article is brought to you for free and open access by the Dublin Energy Lab at ARROW@TU Dublin. It has been accepted for inclusion in Articles by an authorized administrator of ARROW@TU Dublin. For more information, please contact arrow.admin@tudublin.ie, aisling.coyne@tudublin.ie,gerard.connolly@tudublin.ie. Funder: Science Foundation Ireland

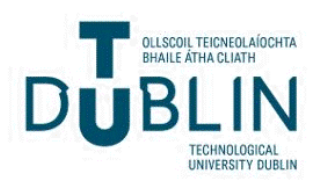




\section{Authors}

Brian Norton, Philip C. Eames, Tapas K. Mallick, Ming Jun Huang, Sarah J. McCormack, Jayanta D. Mondol, and Yigzaw G. Yohanis

This article is available at ARROW@TU Dublin: https://arrow.tudublin.ie/dubenart/56 


\title{
Enhancing the performance of building integrated photovoltaics
}

\author{
Brian Norton $^{\text {a,* }}$, Philip C. Eames ${ }^{b}$, Tapas K. Mallick ${ }^{c}$, Ming Jun Huang ${ }^{d}$, \\ Sarah J. McCormack ${ }^{\mathrm{e}}$, Jayanta D. Mondol ${ }^{\mathrm{d}}$, Yigzaw G. Yohanis ${ }^{\mathrm{d}}$ \\ a Dublin Energy Laboratory, Focas Institute, Dublin Institute of Technology, Aungier Street, Dublin 2, Ireland \\ ${ }^{b}$ Centre for Renewable Energy Systems Technology, Department of Electronic and Electrical Engineering, University of Loughborough, \\ Leicestershire LE1I $3 T U, U K$ \\ 'Department of Mechanical Engineering, School of Engineering and Physics Sciences, Heriot-Watt University, Edinburgh, EHI4 4AS, Scotland \\ ¿Centre for Sustainable Technologies, School of the Built Environment, University of Ulster, Newtownabbey, BT $370 Q B$, Ireland \\ 'Department of Civil Structural and Environmental Engineering, Trinity College, University of Dublin, Dublin 2, Ireland
}

Received 2 October 2009; accepted 2 October 2009

Communicated by: Associate Editor Yogi Goswami

\begin{abstract}
Recent research in Building Integrated Photovoltaics (BIPV) is reviewed with the emphases on a range of key systems whose improvement would be likely to lead to improved solar energy conversion efficiency and/or economic viability. These include invertors, concentrators and thermal management systems. Advances in techniques for specific aspects of systems design, installation and operation are also discussed.
\end{abstract}

(c) 2009 Elsevier Ltd. All rights reserved.

Keywords: Photovoltaics; Buildings; Solar concentration; Inverters; Thermal management; Array sizing

\section{Introduction}

Building Integrated Photovoltaics (BIPV) is a PV application close to being capable of delivering electricity at less than the cost of grid electricity to end users in certain peak demand niche markets (Byrne et al., 1996; Masini and Frankl, 2002). BIPV adoption varies greatly by, and within, country depending upon climate, built environment, electricity industry structure, government polices, local product offerings, market stimulation mechanisms, consumer demand, existing industrial capabilities and the forms of tariff arrangement for grid-connected PV power generation (Green, 2003; Bakos et al., 2003; Watt et al., 1997; Imamura, 1993; Chambouleyron, 1996; Yordi and Gillett, 1997; Hass, 1997; Nieuwenhout et al. 2001). BIPV modularity results in short installation times, and the lack of moving parts reduces the need for maintenance

\footnotetext{
- Corresponding author. Tel.: +3531402 7135; fax: +3531 4027099.

E-mail address: president@dit.ie (B. Norton).
}

(Yewdall et al., 2002). As Japan and some countries in Europe have low specific land use per capita (for the Netherlands, Japan, German and Switzerland, respectively, this is $2680,3060,4450,6000 \mathrm{~m}^{2}$ per capita compared with $37,040 \mathrm{~m}^{2}$ per capita for the USA (Nordmann, 1997)) locating PV on buildings is preferable to specifically devoting land (Strong, 1996a). Grid-connected BIPV - the simplest such low-voltage residential system comprises a PV array and inverter -- feed electricity directly to an electricity network operating in parallel with a conventional electric source and do not usually require/use batteries. The performance of a grid-connected system depends on PV efficiencies, local climate, the orientation and inclination of the PV array, load characteristics and the inverter performance (Kurokawa et al., 1997a,b; Simmons et al., 2000; Miguel et al., 2002).

The very extensive current research on photovoltaic cells has been reviewed extensively elsewhere (see, for example; Green, 2003, 2007; Van Kerchauer and Beaucamie, 2005; Kazmerski, 2006). 


\begin{tabular}{|c|c|c|c|}
\hline & insolation $\left(\mathrm{W} \mathrm{m}^{-2}\right)$ & $T$ & temperature of photovoltaic cell $(\mathrm{K})$ \\
\hline & thermal resistance of photovoltaic cell $\left(\mathrm{KW}^{-1} \mathrm{~m}^{2}\right)$ & $\eta$ & solar energy electrical conversion efficiency \\
\hline
\end{tabular}

\section{Inverters}

An inverter's efficiency in converting PV generated DC power into $\mathrm{AC}$ power determines the $\mathrm{PV}$ generated $\mathrm{DC}$ power required to supply a given $\mathrm{AC}$ load which in turn for specified PV array efficiency sets the PV array size. The performance of an inverter depends on its point of work, threshold of operation, grid connection system, inverter output waveform, harmonic distortion and frequency, PV efficiency, maximum power point tracker (MPPT) and transformer. The main functions of an inverter are waveshaping, regulation of output voltage and operation near peak power point (Kjar et al., 2005).

The three major types of inverter are sine wave, modified sine wave, and square wave inverter. The major advantage of a sine wave inverter is that most equipment available commercially is designed for sine wave operation. A modified sine wave inverter (which has a waveform more like a square wave, but with an extra step) will also operate with most equipment. Static inverters use power semiconductor switches which operate at the cut-off and saturation mode and therefore the output of the waveform is a square wave. A square wave inverter will only generally operate simple devices with universal motors but is much cheaper than the sine wave inverter. Using a power filter, the output square waveform can be converted to a sine waveform. An inverter equipped with a MPPT algorithm extracts maximum power from the PV by varying the input voltage to maintain maximum power point (MPP) voltage on the current-voltage curve as PV output varies with insolation and module temperature (Hussein et al., 1995; Hsiao and Chen, 2002; Takashima et al., 2000; Swiegers and Enslin, 1998; Kuo et al., 2001). The efficiency of an inverter depends on the fraction of its rated power at which it operates. A PV system operates at high-efficiency either when it has a sole inverter operating with a load large enough to maintain peak efficiency or is an interconnection of multiple string inverters, module-integrated inverters or master-slave configurations (Woyte et al., 2000). A sole inverter is supplied from several series-connected PV modules switched in parallel on a DC bus; it can be low-cost and provide high-efficiency but entails a complex DC installation. In a module-integrated inverter each PV module has its own individual inverter. Both string and module inverters are more expensive than a central inverter, however, they obviate the need for expensive DC wiring (Woyte et al., 2000). A master-slave configuration entails multiple inverters connected together; at low insolation, the whole string is connected to just a single inverter operating the inverter at its peak input power level, when insolation increases the PV array is divided progressively into smaller units, until every string inverter operates independently at or near its peak rated capacity. Master-slave inverters can give greater BIPV output (Marańda et al., 1998).

AC module-integrated inverters are located generally at the back of each module converting that module's DC output to $\mathrm{AC}$ power. The advantages of $\mathrm{AC}$ module-integrated inverters are: (i) low resistance losses in cables and connections; (ii) absence of a diode eliminates associated losses; (iii) excess energy can be supplied readily to the utility; (iv) safer than high-voltage DC PV systems; (v) flexibility, ease and low-cost of module installation; (vi) as each module is equipped with a maximum power point tracker, low mismatch losses at system level ensue; (vii) conduction losses and cable costs are low because of the high AC voltage and therefore low current; (viii) lower capital cost due to mass production economies; and (ix) the small size of one AC module lowers barriers to market entry (de Graaf and Weiden, 1994; Wills et al., 1996; de Haan et al., 1994; Yatsuki et al., 2001; Wills et al., 1997). The disadvantages of $\mathrm{AC}$ modules are: (i) increased heating of the inverter located at the back of the module; (ii) increased zero load dissipation compared to a conventional PV system; and (iii) for large PV systems, a central inverter system would be cheaper (de Graaf and Weiden, 1994; Wills et al., 1997).

Inverters are either line or self-commutated. Self-commutated inverters operate independently being activated solely by the input power source; an internal frequency generator provides the correct output frequency. Self-commutated inverters can be connected easily to the grid or any other power source which is tied to the inverter output and for a large PV system three-phase devices are used. Though linecommutated inverters have a lower cost, the AC electricity power quality and power factor are both poor. A PV inverter is either a 'voltage source' or a 'current source' inverter. In a current source inverter the DC source acts as a current source to the inverter (Longrigg, 1982) and needs fault-clearing devices. In the voltage source inverter, the inverter acts as an AC voltage source at its AC terminals (Longrigg, 1982). A PV array operates in the constant-voltage region of the IV characteristics with this type of inverter for stable operation.

Inverter efficiency reaches its maximum usually above $90 \%$ efficiency for an input power level usually between $30 \%$ and $50 \%$ of its rated capacity. However, low efficiency ensues generally at input power levels below $10 \%$ of capacity (Rasmussen and Branz, 1981). When a BIPV module is shaded, the PV output current decreases significantly causing not only the particular module output power to drop but the series-connected PV output power also drops which 
in turn affects inverter performance (Hashimoto et al., 2000). Inverters have been developed specially for BIPV applications with improved maximum power point tracking, reliability and low insolution performance (Kleinkauf et al., 1992; Hashimoto et al., 2000; Shinohara et al., 1992; Noh et al., 2002; Kremer and Diwes, 1998; Stocker et al., 1992; Cendagorta et al., 1998).

Inverter throughput or stand-by losses occur due to (i) operation under low input power resulting in threshold energy loss; (ii) operation under high input power resulting in $\mathrm{DC} / \mathrm{AC}$ conversion loss due to the protective cut-off being activated (iii) increase in inverter temperatures, (iv) coupling of a number of inverters; (v) use of inverters with low operating efficiency; and (vi) operation at part-load conditions (Baltus et al., 1997; Reinders et al., 1999; Blaesser et al., 1994).

The optimisation of a grid-connected BIPV system depends on the relative capacities of the installed PV array and inverter (Kil and van der Weiden, 1994; Nofuentes and Almonacid, 1998; Marańda et al., 1998; Rasmussen and Branz; 1981; Keller and Affolter, 1995; Coppye et al., 1995; Schalkwijk et al., 1997; Mondol et al., 2006a). Optimum grid-connected BIPV system performance in central Europe can be achieved for an inverter rating of $0.6-0.7$ of the array peak BIPV power (Rie and Sprau, 1992; Keller and Affolter, 1992). More generally the optimum ratio of PV array and inverter size for a grid-connected PV system depends on inverter characteristics, available insolation, PV orientation and the PV to inverter cost ratio. Inverter oversizing reduces annual efficiency substantially (Omer et al., 2002, 2003; Mondol et al., 2006a). There are, however, often significant performance differences in superficially similar inverters available commercially (Haeberlin et al. 1997; Veltman et al. 1992). Under the German 1000-roof project it was found that the optimum PV inverter sizing ratio depended on the inverter characteristics and meteorological conditions and varied from 0.8 to 0.9 for low to high-efficiency inverter units when the PV surface was inclined at $45^{\circ}$ (Decker et al., 1992). However, PV system performance is less affected when the sizing ratio ranged between 0.7 and 1.3 and 0.7 and 1.1 for a high and low efficiency inverter PV system, respectively (Decker et al., 1992); the effective sizing ratio for a horizontal surface was found to be within $0.7-$ 1.1 for a high-efficiency inverter system and $0.6-0.9$ for a low efficiency inverter system. In an investigation of the effect of sizing ratio and $\mathrm{PV} /$ inverter cost ratio on the performance of a PV system for various European locations, (Mondol et al., $2007 \mathrm{a}$, b) it was found that for a PV/inverter cost ratio of 6 and for a low efficiency inverter system, the optimum sizing ratio varied between 1.2 and 1.4 for high to low-insolation sites whereas the corresponding variation was from 1.1 to 1.3 for a high-efficiency inverter system.

\section{Building integrated PV products and systems}

When BIPV displaces conventional building materials, savings in the purchase and installation of conventional materials lower the net cost of the BIPV. BIPV walls, roofs, and awnings provide fully integrated electricity generation while also serving as part of the weather protective building envelope (Archer and Hill, 2001). BIPV can serve as a shading device for a window, a semi-transparent glass façade, a building exterior cladding panel, a skylight, parapet unit or roofing system (Hagemann, 1996; Benemann et al., 1994; Maurus et al., 2004). BIPV system output depends on (Kaye et al., 1997; Sidrach-de-Cardona and López, 1999; Imamura et al., 1992).

- the availability of and access to solar radiation as determined by climate, inclination, latitude, orientation and the urban setting (Norton, 1992; Waide and Norton, 2003; Yun and Steemers, 2009) of available building surfaces,

- PV efficiency and its degradation with time (Simmons and Infield, 1996),

- efficiency of balance of system components (Miguel et al., 2002),

- coupling to the electrical network, electrical wiring resistance and voltage drop in diodes (see Section 4.4),

- partial overshading (see Section 4.6),

- accumulation of dirt, dust or snow on modules (see Section 4.5).

The optimum design of a BIPV system although based on a building's electrical load profile, PV output and balance-of-system characteristics, must be cogniscent of building design constraints, building location, offset costs, climate, and future load growth (Watt et al., 1998a). System economic viability depends on local electrical loads and utility prices (Mondol et al., 2006a). Approximately 25-30\% (Sick and Erge, 1996) of energy consumed in buildings in industrialised countries is as electricity. Photovoltaics can be integrated on virtually every conceivable structure from bus shelters to high rise buildings. BIPV modules fabricated directly onto building materials, can, in high-volume production lead to lower substrate, distribution and installation costs (Jäger-Waldau, 2006). There would be some additional cost associated with the BIPV wiring, but this would be minimal in new construction. The peak power cost for large-scale, BIPV systems could drop to less than $\$ 1 / \mathrm{Wp}$, which should lead to PV electricity costs comparable to large centralised power plants, i.e., less than 10 cents per kWh (Lin and Carlson, 2000). Moreover, since some of the PV power would be used in the building, the demands on the power grid are reduced and the reliability of supplied power to the building is improved. With the advent of low-cost storage, a network of BIPV systems could become a reliable, distributed power source, which would be immune to widespread disruptions ( Lin and Carlson, 2000). Another potential significant advantage is that the heat collected by PV modules can also be used for space heating or hot water-heating (see Section 8.3). From architectural, technical and financial perspectives (Rüther, 1998; Archer and Hill, 2001; Sick 
and Erge, 1996; Posbic and Rever, 1998; Yoo et al., 1998; Oliver and Jackson, 1999), BIPV

- when grid-connected, avoids the costs of batteries, associated BOS and possible system oversizing;

- reduction of investment costs by displacing façade/roof/ shading elements;

- can be aesthetically appealing;

- electricity is generated at the point of use, reducing the impacts, costs and losses associated with transmission and distribution (Paatero and Lund, 2006);

- is suitable for unshaded roofs and facades in densely populated areas;

- no additional land area required, since building surfaces used;

- can be designed to generate electricity at a building's peak usage times particularly for commercial buildings, thus reducing the building's peak grid electricity demand;

- may satisfy all, or a significant part, of the electricity consumption of the building;

- can act as shading devices (Sala et al., 1996; Von Bussue et al., 1996; Miller et al., 2005);

- can form semi-transparent elements of fenestration (Maurus et al., 2004);

- $\mathrm{PV} / \mathrm{T}$ can provide part of the water or space heating loads of the building (see Section 8.3) or more specific uses by, for example acting as the evaporator of a solar-assisted heat pump system (Ji et al., 2008);

- BIPV can form part of a grid-failsafe antennae system for cellular communications (Roo Ons et al., 2007, 2008).

BIPV can be of the form of (i) roofing materials, (ii) wall and fenestration materials (Bendel et al., 1995), and (iii) flexible photovoltaic modules (Shinjo, 1994; Uehara, 1997) and can be integrated to the roof of new buildings or where major roof replacement is undertaken. Methods of integration include exchangeable PV shingles, prefabricated PV roof panels, and insulated PV roof panels (Shinjo, 1994). Fullyintegrated BIPV roofing systems must perform the function of a standard roof and provide water tightness, drainage, and insulation. Most retrofitted roof-mounted systems are though not however fully integrated into the roof structure (Watt et al., 1999; Yamawaki et al., 2001). Roofs offer an attractive location for BIPV because of:

- unshaded solar access,

- the cost is offset partially by the displacement of roofing materials by BIPV modules (Nitta et al., 1994) (Chowdhury et al., 1997),

- flat roofs generally enable more optimal solar cell placement and orientation, and

- when a pitched roof is near optimally inclined, the need for and cost of a support frame is eliminated.

A methodology combined data for land use, population building densities with statistically representative maps of urban areas provided by a vectorial geographic information system to determine estimate the roof area available for PV in Spain and it geographic distribution (Izquierdo et al., 2008). Though the method used a limited set of 16 representative building typologies it was found to be scalable and provided the error associated with the estimate.

Many roof-integrated (as apposed to roof-mounted) BIPV are module-based roof tiles (Bahaj et al., 1998), slates (used on flat roofs), shingles or standing seam (for tilted roofs) units. The design of a PV tile or shingle conforms usually to regional or local roofing methods and building codes, so the market for one particular BIPV roofing system may not be applicable to a wide range of countries and many proprietary roof-integrated BIPV systems are available. The "Solbec" system for integrating photovoltaic modules on flat roofs (Bonvin et al., 1997) is made of fibre elements and available in three sizes with multiple possible configurations, easy maintenance and a quick interlocking mounting process. The "SOFREL" modular flat roof PV integration system (Muller et al., 1996) uses standard prefabricated concrete slabs with concrete plinths whose base includes ballast to maintain the structure in place. The wiring of the module is placed underneath the concrete base (Schalkwijk et al., 1995). In the "PowerGuard" PV roofing assembly system, a-Si PV modules act as insulation to the roof protecting the roofing membrane (Dinwoodie and Shugar, 1994) thereby eliminating need for a PV support structure. A frameless exchangeable PV shingle using monocrystalline or polycrystalline cells as shown in Fig. 1 (Okuda et al., 1994; Yagiura et al., 1997) consists of solar cells encapsulated between tempered glass and a metal back plate with an integrated mounting bracket. A roof-integrated PV module made of untempered glass is shown in Fig. 2 (Nitta et al., 1994). The "SUNSLATE", PV-roof and façade system is made with an integrated contact bar, diode on a standard roof or façade slate (Posnansky et al., 1997), the solar cell is encapsulated between solar glass and a coated aluminium sheet and embedded into ethylene vinyl acetate. Another PV roof tile using monocrystalline silicon solar cells has been developed with the upper and underside of the tile made of acrylic and polyvinylchloride, respectively. To enable integration with conventional roofing tiles, it has easy replacement and installation and simple wiring connections (Bahaj et al., 1998). A particular type of a-Si shingle developed to replace conventional roofing shingles (Izu et al., 1994) was several times longer than conventional roofing shingles. In another integral a$\mathrm{Si}$ alloy-based photovoltaic roofing element, the top outer cover of the module is made of fiuoropolymer film and laminated to the cell surface using EVA material (Nath et al., 1994, 1998); the module being of similar shape to a conventional batten and sheet metal roofing element, was used as a standing seam-roofing element using an integral locking system to join panels. The "solar tile" PV roof tile has been developed for integration into clay roof tiles (Meier and Hasler, 1992). Many BIPV roofing 


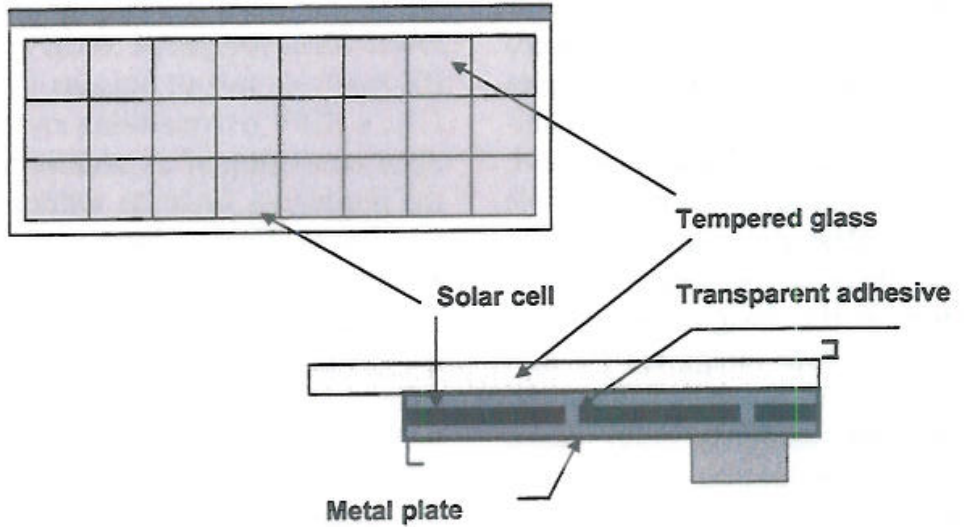

Fig. 1. Structure of exchangeable PV shingle (Yagiura et al., 1997).

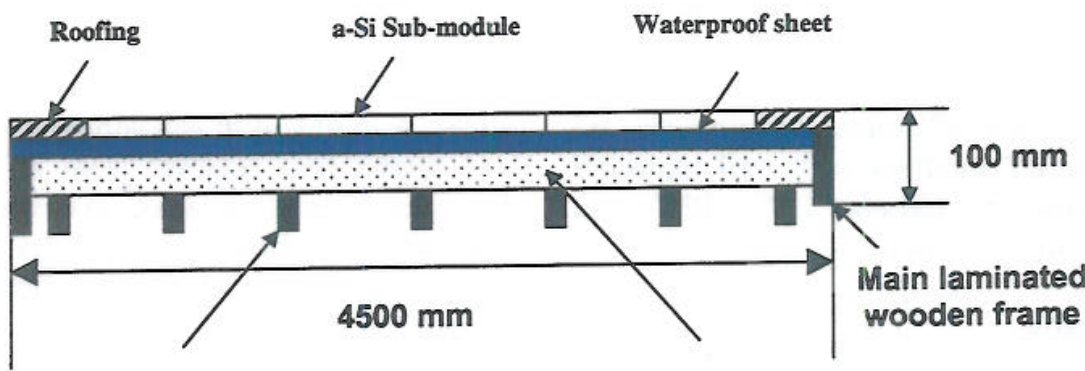

1.1.1 Polystyrene thermal insulation

Fig. 2. Sectional view of a roof-integrated PV module (Nitta et al., 1994).

modules have been developed whose size and shape are the same as conventional tiles and interconnected by waterproof leads (Matsuoka et al., 1990; Strong, 1996b; Ishikawa et al., 1994a; Horigichi et al., 1996; Yoshida et al., 1996; Murata et al., 2003). An example is shown in Fig. 3.
PV roof tiles with static concentrators provide cost savings by reducing the PV area using low-cost concentrating elements (Bowden et al., 1993; Wenham et al., 1995). A roof tile has been developed using low-cost lenses (Bowden et al., 1993, 1994). The front surface of the high-efficiency bi-facial solar cell module is covered with glass, the rear
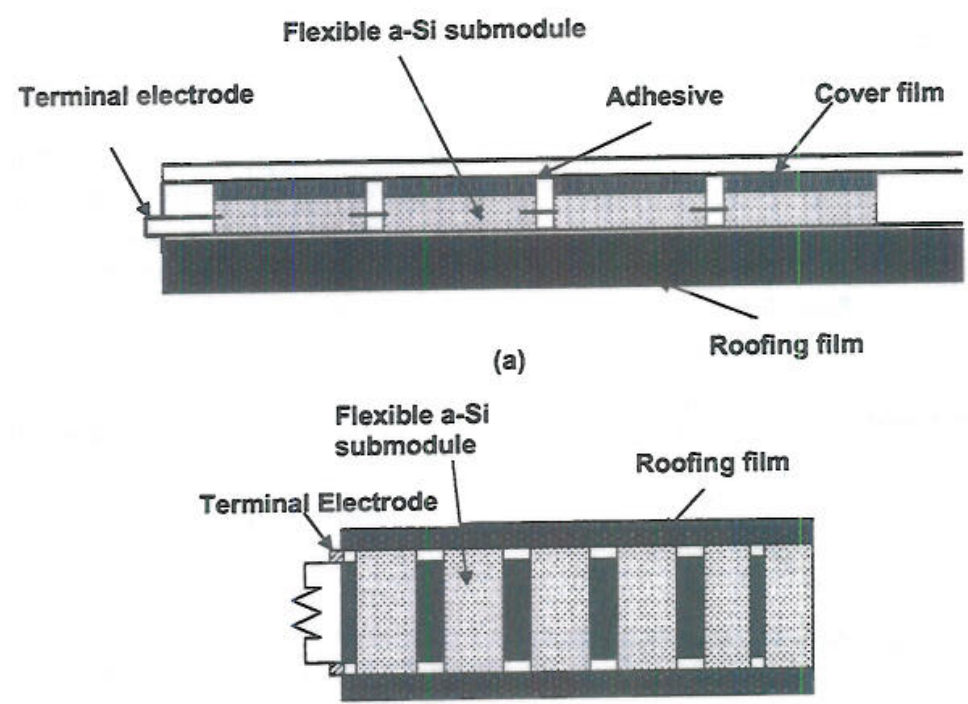

(b)

Fig. 3. Structure of solar roofing (a) sectional view; (b) front view (Ishikawa et al., 1994a). 
surface is reflective and grooved. The static concentrator was constructed from acrylic. The construction of the module is shown in Fig. 4. Both atria and skylight technologies are suitable for PV integration, with transparent PV laminates replacing the glazing units directly. Large frameless, lightweight, roof-integrated PV modules are available made of transparent, toughened glass with toughened float glass on the front and back surfaces (Wambach, 1998). Several studies have reported on the design, installation, and the performance of such glass roof-integrated PV systems (Reijenga and Böttger, 1997; Humm and Toggweiler, 1993; Sala et al., 1995; Mosko and Niephaus, 1995). James et al. (2009) undertook a critical evaluation of electricity generated, shading provided and comfort enhanced by a atria with semi-transparent PV roof glazing elements in the UK climate. It was found that taking all those factors into account could render the total system viable both economically and in regard to averted carbon dioxide emissions.

PV glass curtain-walls and PV metal curtain-walls are used for integration of PV modules with wall materials (Shinjo, 1994; Toyokawa and Uehara, 1997). BIPV can be integrated into the building facade as:

- rainscreen overcladding,

- structural glazing mullion/transom curtain-wall systems,

- pressure plate mullion/transom curtain-wall systems,

- panel curtain-wall systems, and

- profile metal cladding.

The outer leaf of rainscreen cladding acts as a rain barrier and the inner leaf acts as an barrier (Scott et al., 1992). Crick et al. (1995) proposed design guidelines of PV rainscreen overcladding, as installed in the, UK (Hill et al. 1994). Curtain-wall façades consist of a metal frame with transparent and opaque panels. A PV module integrated with a metal curtain-wall composed of glass, EVA, polycrystaline silicon solar cells and aluminium base plate has been developed for use in Japan (Yoshino et al.,

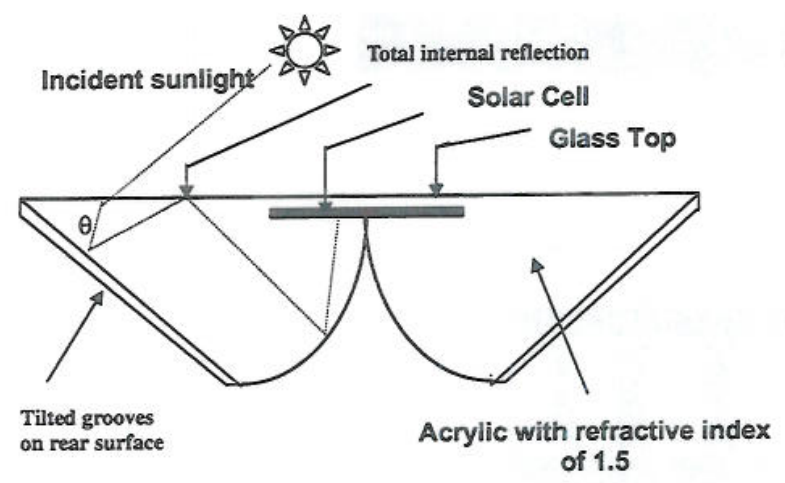

Fig. 4. Construction of PV roof tile with static concentrator (Bowden et al., 1994).
1997). The module temperature was approximately $10^{\circ} \mathrm{C}$ lower when compared to the conventional superstrate-type PV modules for all seasons (Yoshino et al., 1997). In the UK, a BIPV overcladding and curtain-wall has been developed consisting of an aluminium heat sink on the back of the module in order to reduce the PV temperature (Bahaj and Foote, 1994). Lloret et al. (1995) reported a ventilated element consisting of a PV laminate for use in facades. BIPV modules have been developed as conventional glazing elements on facades and roofs (Benemann, 1994; Laukamp et al., 1994).

When PV systems are integrated onto the building façade using a pressure plate system, the glazing unit is mechanically held from the front by a plate with an extended cover; minimal, mullion cap depth is essential to avoid PV shading. Alternatively, the flush application of a structural silicone seal between curtain-wall framed PV glazing units eliminates shading but can give rise to delamination due to moisture ingress at less durable PV panel edges. A double-wall envelope minimises sealing problems and allows heat removal from PV modules. PV glazing forms an external, unsealed layer with the inner layer forming a weathertight enclosure. In designing for building integration of PV it is obviously crucial that the structure is capable of bearing the wind-loaded weight of PV modules. Overheating of PV elements may result due to weathertight seals; for example a sealed façade in Austria produced 4\% less energy annually when compared to a cooler rear ventilated system (Wilk, 1994). Design for natural ventilation behind the BIPV elements can enable a temperature reduction of up to $20 \mathrm{~K}$ to be achieved (see Section 8). This both increases the electrical output and reduces building heat gain (Brinkworth et al., 1997). Aesthetic appearance is important particularly for prestige commercial curtain-wall façades and has led to the manufacture of coloured PV cells. The need to accommodate wiring in façades, which are often designed to appear frameless can also impact adversely upon façade appearance (Watt et al., 1999). Glazed PV modules (c-Si and a-Si) and modules which are deposited onto a metal or other substrate (a-Si) require different approaches to fabric integration (Crick et al., 1998). Façades are shaded more frequently than roofs; non-homogeneous shading of a PV façade will impact upon the electrical configuration, including the number of series and parallel strings, redundant interconnections and inverter sizing (Groehn and Brathels, 1994).

\section{Performance of grid-connected BIPV systems}

\subsection{System performance ratio}

The system availability of BIPV system during sun hours is defined as the number of hours of load requirements in a period divided by number of hours for which insolation was sufficiently intense for the system to generate power (Jahn et al., 1994, 1998). The performance ratio (PR) expresses the performance of a PV system in compar- 
ison to a lossless system of the same design and rating at the same location (i.e., the system efficiency under realistic reporting conditions ( $R R C$ ) divided by the module efficiency under standard test conditions (STC) (Simmons and Infield, 1996)) and indicates how close a PV system approaches ideal performance during real operation (Blaesser, 1997). The PR is independent of location and is influenced by:

- insolation (as the efficiency of PV array depends on irradiance);

- the combined efficiency of the system components;

- relative sizing ratio of inverter and PV array, i.e., ratio of inverter rated power to the PV rated power; (see Section 2);

- the extent to which the system output is being used (Mondol et al., 2006b); and

- system layout (Blaesser et al., 1994; Decker and Jahn, 1997; Mondol et al., 2006a; Baltus et al., 1997).

The PR of systems with identical PV modules, inverters and $\mathrm{BOS}$ components can differ by up to $30 \%$, mainly due to shading losses (Decker and Jahn, 1997). Average BIPV PR should reach, and preferably exceed, 70\% (Kurokawa et al., 1997a; Haas et al., 1999; DeGheselle, 1997; Miguel et al., 2002; Pietruszko and Gradzki, 2003). A BIPV system PR of less than $70 \%$ is indicative of a combination of some of the following factors:

- Long-term partial shading (Steinhardt et al., 1998); Sugiura et al., 2003; Schroeder and Kreider, 1998).

- Inverter operation under or near its threshold energy (Sidrach-de-Cardona and López, 1999; Mondol et al., 2007a,b; Ubertini and Desideri, 2003; Bahaj et al., 2001).

- Inverter shutdown during high insolation or power failure (Simmons and Infield, 1996; Sugiura et al., 2003).
- Unstable inverter control and failure of magnetic circuit breakers (Sugiura et al., 2003).

- Coupling problems between the inverter and the grid (Sidrach-de-Cardona and López, 1999).

- High PV temperatures (Pearsall et al., 1997, see also Section 8 of this paper).

- Winter snow cover (Kiefer et al., 1995), and

- Inefficient MPPT (Bahaj et al., 2001, see also Section 4.4. of this paper).

\subsection{Sources of losses}

PV system losses comprise: (i) avoidable losses which include the difference between actual nominal power, manufacturer's rated power and mismatch losses and (ii) unavoidable losses which include transmittance, low irradiance and temperature losses (Caamaño and Lorenzo, 1998). Table 1 shows losses associated with a PV system (Townsend et al., 1994; Sugiura et al., 2003; Schaub et al., 1994; Steinhardt et al., 1998; Kiefer et al., 1995; Baltus et al., 1997; Decker et al., 1992; Imamura, 1994; Simmons and Infield, 1996; Mukadam et al., 1995; Peterson et al., 1999; Suzuki et al., 2002; Anis and Nour, 1995; Román et al., 2006; Fanney et al., 2001).

\subsection{Spectral and optical losses}

PV device output varies according to their specific spectral selectivity as the solar spectrum alters due to changes in air mass and relative humidity (Hirata and Tani, 1994) an $-1 \%$ to $-2 \%$ annual spectral loss is associated with modules that have a broad spectral response (Nann and Emery, 1992; Bücher, 1997) and a $+4 \%$ to $-15 \%$ for a narrow spectral response (Bücher, 1997). Better spectral matching has been shown to give rise to higher PV efficiency in summer (Rüther and Dacoregio, 2000). Larger average air mass at

Table 1

A summary of percentage losses in PV systems due to operational parameters.

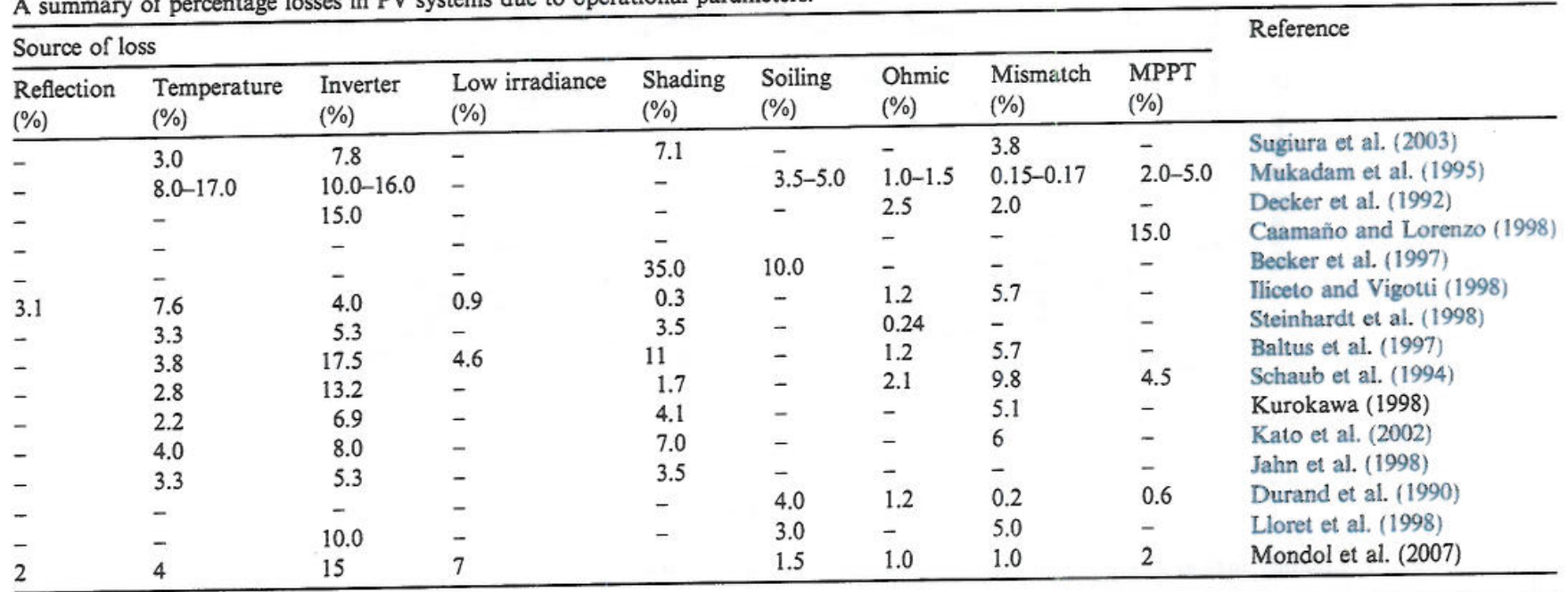


low sun angles shift the spectrum towards red causing a decrease in efficiency (Pratt and Burdik, 1988).

Reflection loss from the module surface, (also referred to as angular loss) depends on module orientation and tilt angle, solar position and geographical location of the site (Reinders et al., 1999; Martin and Ruiz, 2001) with the reflection loss being higher for vertical surfaces close to the equator (Bücher, 1997). Anti-reflection coatings are included in many modules. Fig. 5 illustrates the dependence of angular loss on location and tilt angle and Fig. 6 shows the variation of annual angular loss as a function of tilt angle for different European locations. The measured yearly reflection losses of crystalline modules have ranged within $6.7-10.8 \%$ with reflection loss increasing from $10 \%$ to $13 \%$ as the PV orientation changed from the optimal to vertical orientation (Lanzerstorfer et al. 1995) and declining at least $2 \%$ when PV inclination changed from $48^{\circ}$ to $90^{\circ}$ (Preu et al., 1995).

Accrual of dirt and other particles on a PV module surface reduces insolation transmission (Goossens and Kerschaever, 1999; Reinders et al., 1999; Gonzalez, 1986). Annual soiling losses vary from $2 \%$ to $8 \%$ but in dry summers soiling loss could be over 20\% (Maag, 1977; Townsend and Whitaker, 1997). Soiling loss depends on the module front surface material, the site microclimate and local dust sources, the frequency of cleaning by rain or manually (Hoffman and Maag; 1980), and increases with the inclination of the PV surface (Nakamura et al., 2001).

\subsection{Electrical losses}

The efficiency of a PV module decreases when it operates at irradiance level lower than STC resulting in a drop in module efficiency due to recombination currents, parallel resistance, and other effects (Bucher et al., 1998). The low irradiance loss could be within the range of 1-5\% (Iliceto and Vigotti, 1998; Baltus et al., 1997). Typically there is a 1-3\% resistance (or ohmic) loss (Mukadam et al., 1995; Decker et al., 1992) due to cable resistance, contact resistance in terminals, fuses and connectors or disconnectors. There are two primary losses associated with any array circuitry: the loss due to the resistivity of the array wiring series resistance; and that due to drops in array voltage in diodes (Gonzalez, 1986).

Mismatch loss is caused by variation between I-V characteristics of coupled PV modules due to manufacturing defects and inhomogeneous and/or partial shading caused by surrounding objects. Mismatch loss is due to either current mismatch or voltage mismatch (Gonzalez, 1986). Current mismatch occurs when low current modules are present in a series string or when a portion of the array is shaded; if the current and voltage of the modules are not matched, modules providing low output determine the overall array output. Voltage mismatch arises when cells are shorted (Gonzalez, 1986). Cells connected in series or parallel operate at the same current or voltage resulting in significant energy loss when the operation of cells is limited by the cell power with the lowest peak output (Bucciarelli, 1979). Mismatch loss can be determined by either measuring the I-V characteristics of each string and comparing them with each other or measuring the real array efficiency in the field and then making corrections for the module temperature and cable losses (Baltus et al., 1997). PV modules generate maximum power when the array voltage is equal to the voltage at the MPP (Baltus et al., 1997). Maximum power point tracking (MPPT) loss occurs when the power produced by a PV array deviates from the expected value. This loss can be two types: static MPPT loss which is determined by the efficiency of the MPPT under stable irradiance conditions (Reinders et al., 1999),

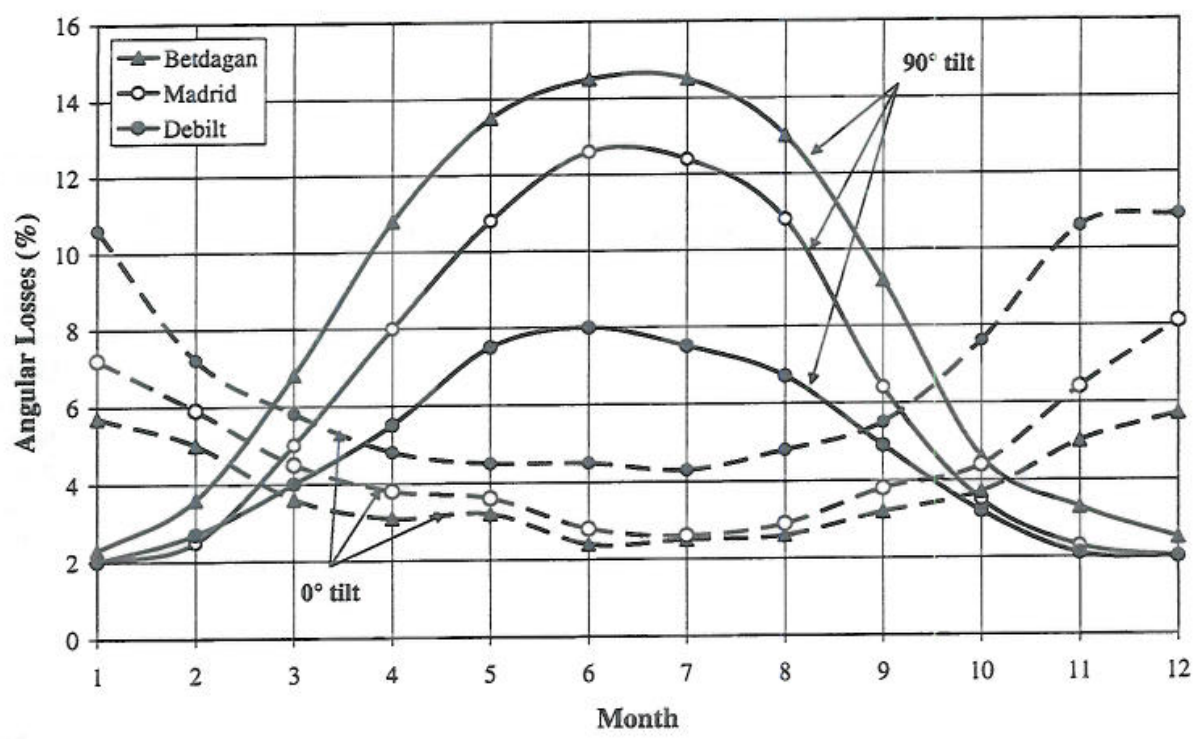

Fig. 5. Monthly angular losses of a standard m-Si module as a function of tilt angle for three locations (Martin and Ruiz 2001). 


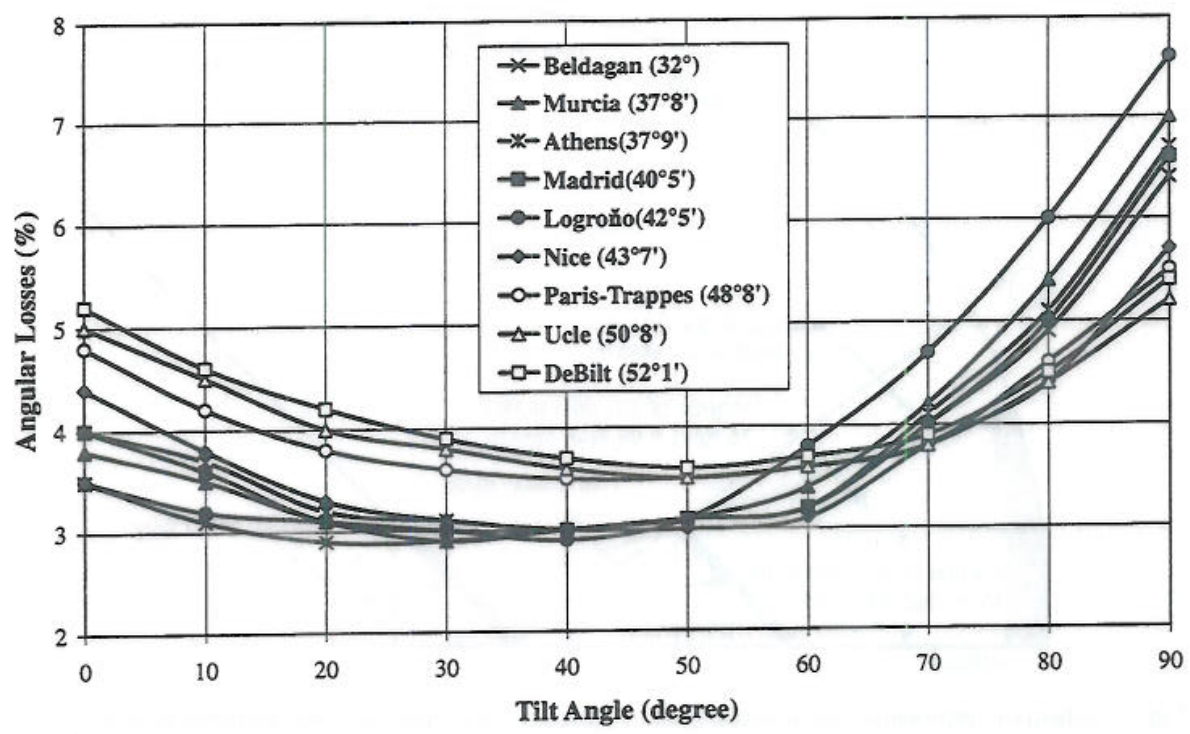

Fig. 6. Annual angular losses as functions of tilt angle for different sites (Martin and Ruiz 2001).

and dynamic MPPT loss caused by a slow MPPT searching algorithm; fast fluctuating insolation causing rapidly varying array power that may not be detected correctly by a slow voltage domain tracker (Reinders et al., 1999). Generally the lowest MPP losses occur when modules are sorted based on MPP current and highest when sorted by voltage (Wilshaw et al., 1997). The incremental conductive method of MPPT has been shown (Román et al., 2006) to give the best performance.

Array capture losses are - often indeterminate - combinations of thermal capture losses caused by the operating temperature of the module and miscellaneous losses caused by wiring, string diodes, low irradiance, partial shading, dirt accumulation, snow covering, inhomogeneous irradiance, cell mismatching, maximum power point tracking, inefficient system components or system failures (Miguel et al., 2002). PV cells also lose power output over time, aging of cells can reduce power to as much as $80 \%$ of original power over 20 years. The initial loss of PV efficiency is due to the Steabler-Wronski effect, (Simmons and Infield, 1996; Van Dyk et al., 2002; Rüther and Dacoregio, 2000) it is suggested that maximum power point tracking devices should be based on the degraded module performance. The DC PR of an a-Si PV system typically falls from $80 \%$ to $65 \%$ due to initial system degradation (Ossenbrink et al. 1994; Dunlop et al. 1997). Applying separate MPPT to each module (rather than to the array as a whole) allows it to operate at maximum power irrespective of the possible shading or differing orientations of other modules in the array (Román et al., 2008).

\subsection{Tilt angle, orientation and seasonal losses}

Using a validated simulation model, the maximum annual system PR of a roof-mounted BIPV system at a lat- itude of $54^{\circ} \mathrm{N}$ in the UK was found to be for a south facing surface inclined at $20^{\circ}$. For horizontal and vertical south facing surfaces the system PR was estimated to be $1.6 \%$ and $18.1 \%$ lower, respectively, than the maximum value (Mondol et al., 2007a). For a location at latitude $35.7^{\circ} \mathrm{N}$ maximum annual energy was obtained for the surface with tilt angle $29^{\circ}$ (Soleimani et al., 2001). For both these locations, these optimal inclinations show the strong contribution diffuse insolation can make to the total solar energy incident annually on a BIPV array.

For seasonally-tracking arrays, annual PV output can be $94 \%$ to $96 \%$ of the maximum annual PV output when optimum tilt angle is selected only once a year and $99 \%$ of the maximum annual PV output if the optimum angle is adjusted twice a year (Balouktsis et al., 1987). Different methods are available to obtain optimum tilt of a PV system based on the latitude, local climates, insolation conditions and energy demand (Tsalides and Thanailakis, 1985; Kern and Harris, 1975; Bari, 2000; Mondol et al., 2007a) and location - specific measurements have been reported of the seasonal dependence of PV system performance (Rüther, 1998; Marion and Atmaram, 1990; Oladiran, 1995; Akhmad et al., 1994; Sopitpan et al., 2001; Pearsall et al., 1997; Molenbroek et al., 1998; Itoh et al., 2001; Hiraoka et al., 2003).

\subsection{Shading losses}

Shading can, as shown in Fig. 9 result in an output energy loss of $25 \%$ (Gross et al., 1997). Shading loss arises due to the difference of insolation on shaded and unshaded parts of a PV array (Schroeder and Kreider, 1998; Alonso et al., 1997; Lloret et al., 1998; Omer et al., 2003; Budin and Budin, 1982; Blewett et al., 1997). Shading loss may be due to the diffuse component of insolation being different on different modules (Gonzalez, 1986) as shown in Fig. 7, or 


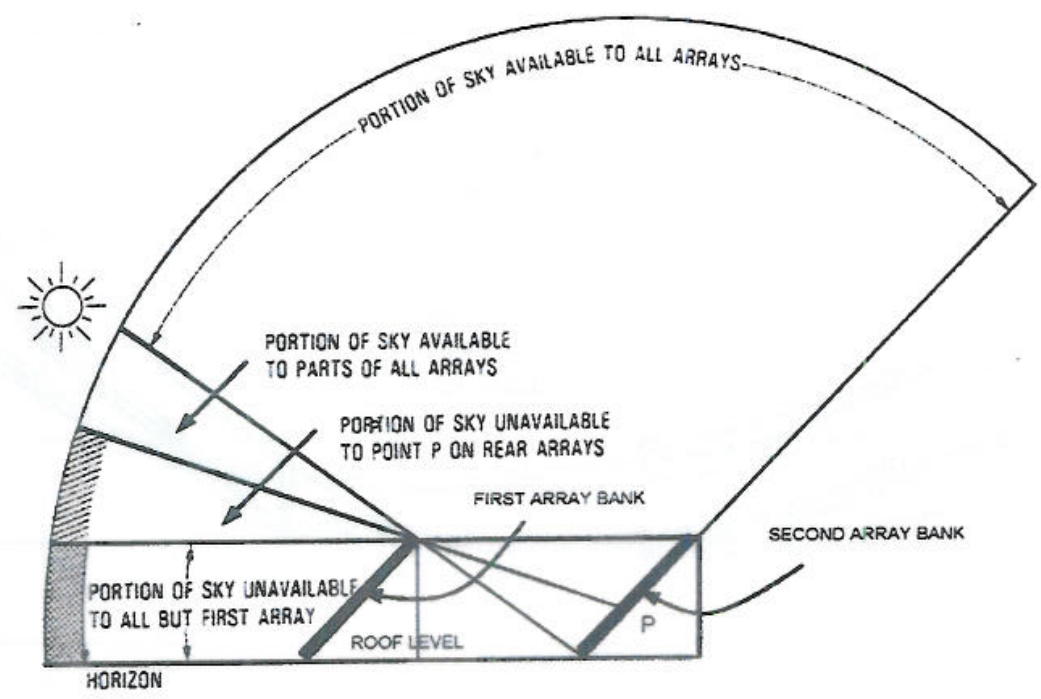

Fig. 7. Schematic representation of array shadowing from the diffuse radiation component (Gonzalez, 1986).

obstruction by other arrays or nearby objects (Reinders et al., 1999; Alonso et al., 1997). Shading affects PV performance by (Alonso et al., 1997): (i) hot-spot formation due to non-uniform illumination causing heating of the module and performance detoriation; (ii) reduced inverter performance due to instability in inverter MPP tracking and/or (iii) poor output waveform quality due to the decrease in the MPP voltage. Shading loss can be reduced by using modules with cell-integrated bypass diodes, employing small-scale inverters and using MPP trackers (Quaschning and Hanitsch, 1998; Bruendlinger et al., 2006). As shown in Fig. 8 relative shading loss increases with raised shading angle. Iliceto et al. (1997) reported that the partial shadowing during early and later parts of a day in winter months caused a $5 \%$ energy loss that reduced the yearly perfor- mance by only $0.3 \%$. Whereas Omer et al. (2002, 2003) found a $27 \%$ reduction of annual PV output for two BIPV systems in the UK. Lloret et al. (1998) observed 3\% power losses due to shading effects and soiling losses.

\section{Economic optimisation and viability}

\subsection{Sizing parameters}

BIPV sizing depends on the following:

- Insolation: PV output varies directly with the amount of insolation available at the site. Other climatic factors which influence PV output are: temperature, precipitation, wind speed and land topology. The scattering of

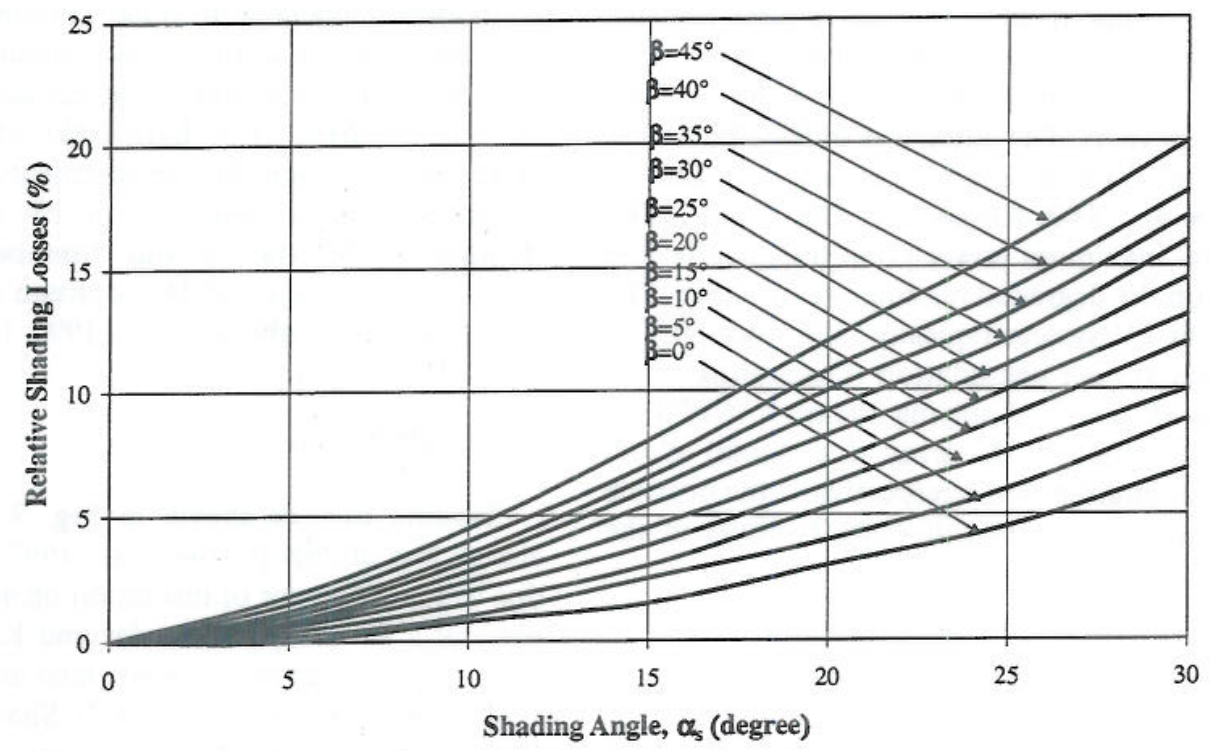

Fig. 8. Relative shading loss as a function of shading angle and module tilt angle (Quaschning and Hanitsch, 1998). 


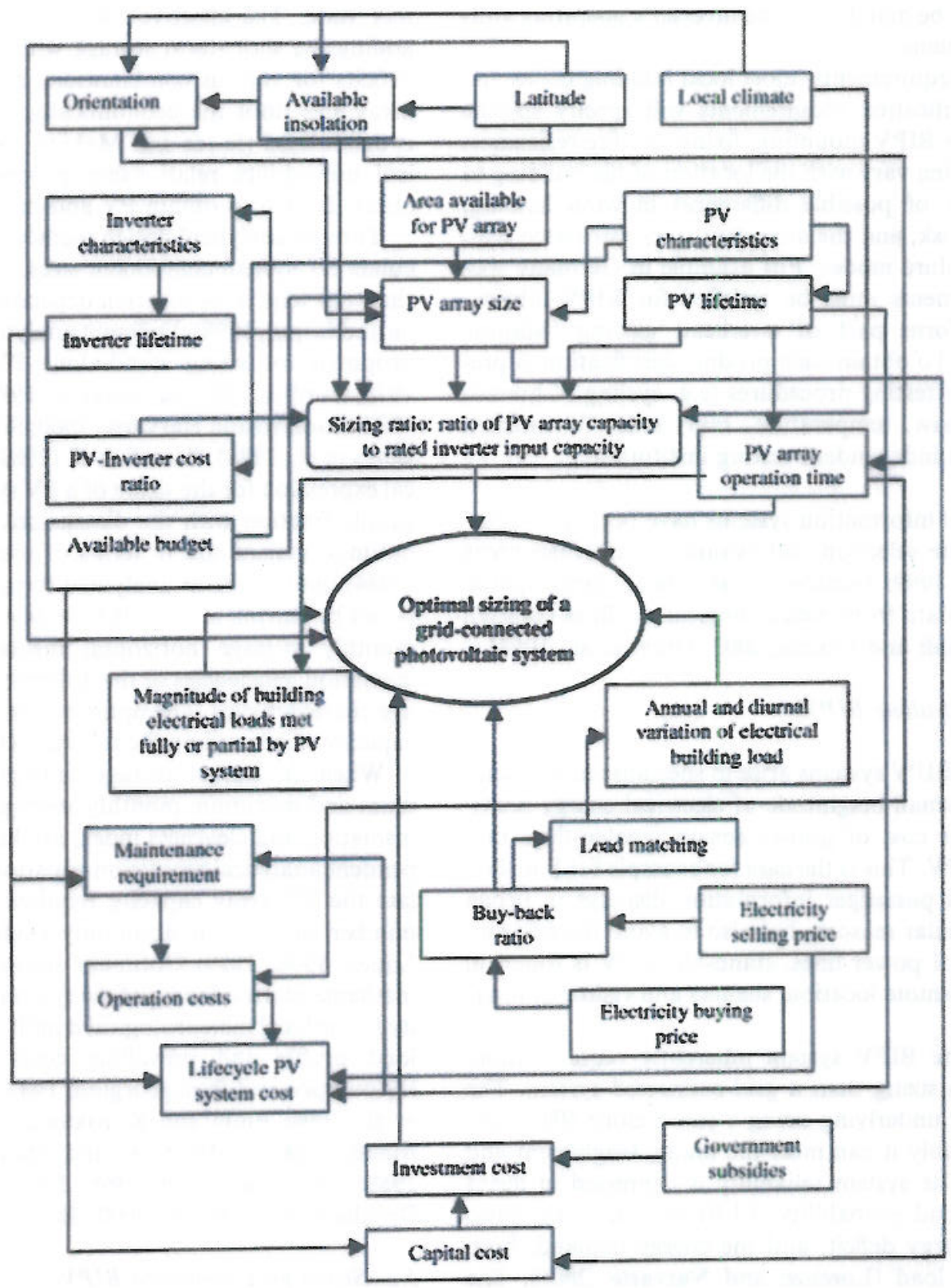

Fig. 9. Interactions of influences on PV system sizing (Mondol et al., 2006a).

albedo from snow-covered ground, inclination of the surface and the characteristics of topology of the terrain in front of the PV plants may increase the performance of a PV system (Brack et al., 1992; Sugiura et al., 2003).

- Nearby roof structures and surrounding objects can cause shading which will reduce PV performance.

- Area: PV installations require larger surface areas to meet larger loads. For a BIPV system, orientation and inclination also affect PV output with optimum orientation and inclination usually determined to be the surface which receives the highest utilisable (i.e., can be harnessed by a load) insolation (Mondol et al., 2006a).

- Economics: The economic factors which influence the cost of PV generated electricity are PV and BOS cost, and installation costs. In addition any grants, incentives subsidies or special purchase arrangements are important factors (Sick and Erge, 1996).

- Load: A realistic estimation of load profile to be satisfied is the first step in the design of a stand-alone BIPV system design. For a stand-alone PV system, the operating voltage is selected equal to the voltage required by the largest load (Sharma et al., 1995). In grid-connected BIPV applications the economically optimal diurnal load to be met by the PV will not correspond to the total load particularly at night and (in high latitude locations) in winter. For a grid-connected BIPV system overproduction on an annual basis must be avoided (though such gross oversizing is unlikely) and the DC system 
voltage must be matched to the inverter's operating voltage requirements.

- Regulatory requirements: most local building codes and product certification requirements will specify specific standards for BIPV mounting, fixing and fire resistance. These will often vary with the location of the building to take account of possible differences in wind loading, earthquake risk, and the attendant risks associated with particular failure modes. For example in Germany specific requirements must be satisfied for BIPV fabrications that form part of overhead glazing (Maurus et al., 2004). To obtain such product certification, a prescribed set of testing procedures (e.g. cycling of humidity, freeze/thaw, temperature, rain) must be satisfied usually in an independent testing institution.

Geographical information systems have been used effectively for PV site selection and evaluation in urban areas (Muselli et al., 1999; Gadsden et al., 2003), using spatial solar radiation data from meteorological satellites (Muselli et al., 1998; Maafi and Lounis, 2002; Otani et al., 1994).

\subsection{Sizing stand-alone $B I P V$}

Stand-alone BIPV systems arise in specialist small buildings where the small magnitude of electrical energy provision renders the cost of grid-extension greater than that of installing BIPV. This is the case for example for bus shelter lighting and passenger information displays in urban settings. For similar reasons, but also to avoid the environmental impact of power lines, stand-alone PV is found in many park, or remote location, shelters and visitor or interpretive centres.

A stand-alone BIPV system inherently requires more accurate system sizing than a grid-connected system. The primary criteria underlying sizing a stand-alone BIPV system is how reliably it can meet the load (Benghanem and Maafi, 2000). The system reliability is expressed in terms of the loss of load probability (LLP) defined as the ratio between the energy deficit, and the energy demand, both referred to the load (Lorenzo and Narvarte, 2000). The main sizing parameters of a stand-alone BIPV system are PV array and storage capacity and the LLP (Narvarte and Lorenzo, 1996). PV array capacity is the ratio of mean PV energy production to the mean energy load demand. The storage capacity is the ratio of mean energy taken out from the accumulator (battery) to the mean load energy demand. Methods have been proposed for sizing stand-alone PV systems which can be divided into: (i) intuitive methods, (ii) numerical methods, and (iii) analytical methods (Sidrach-de-Cardona and López, 1998). Intuitive methods provide an initial rough estimate of the likely system dimensions (Sidrach-de-Cardona and López, 1998; Lorenzo and Narvarte, 2000).

When using numerical methods, PV and battery size are calculated by means of system simulation using either an hourly or daily energy balance of the system and the bat- tery state. The effective battery capacity is estimated by adding the short-term storage with the year-round energy deficits for various combinations of PV surface slope and array size until the economically optimum configuration is determined (Soras and Makios, 1988). A similar analytical utilizability relationship proposed by Bartoli et al. (1984) is used to obtain PV and battery size.

Though analytical design methods are easy to use to calculate PV system component sizes, their main drawback is that they tend to be location dependent (Sidrach-de-Cardona and López, 1998). Different analytical methods have been proposed for sizing stand-alone PV system (Bucciarelli, 1979; Gordon, 1987; Bartoli et al., 1984; Egido and Lorenzo, 1992; Lorenzo and Narvarte, 2000; Soras and Makios, 1988; Barra et al., 1984). Bartoli et al. (1984) proposed an analytical expression for the sizing of a PV system which relates PV supply fraction with the dimensions of its components to optimise system size in terms of overall cost. Barra et al. (1984) used a similar analytical form of the equations proposed by Bartoli et al. (1984) to develop a model that used monthly average horizontal insolation, extra-terrestrial insolation, efficiencies of the different components and storage characteristics. The optimisation of the PV and storage capacity was based on the minimum system cost.

When the annual average daily global insolation, minimum and maximum monthly average daily global in-plane insolation and clearness index, are known, a location independent analytical regression equation can be used to calculate the PV array capacity required to satisfy a specified number of days of autonomy (Sidrach-de-Cardona and López, 1998, 1999) Optimum sizing techniques based on mathematical modelling of the system components, sensitivity to the local meteorological conditions, system reliability, load profile and prevailing costs have been reported (Groumpos and Papageorgiou, 1987; Negro, 1995; Notton et al., 1996; Endo and Kurokawa, 1994; Benghanem and Maafi, 2000; El-Hefnwai and Hanafi, 1998; Chapman, 1989; Lasnier and Juen, 1990; Kaye, 1994; Shrestra, 1998; Benghanem and Maafi, 2000; Sharma et al., 1995).

\subsection{Sizing grid-connected BIPV}

Grid-connected BIPV systems may be designed at different times to (i) meet a fraction of total electrical load of the building, (ii) have all their output delivered to a grid and/or (iii) deliver excess energy generated into the grid. The optimum sizing of a grid-connected BIPV system is influenced by many factors as illustrated in Fig. 9 (Mondol et al., 2006a; Sick and Erge, 1996, Oshiro et al., 1997; Yukawa and Kurokawa, 1994; Hernández et al., 1998; Nofuentes and Almonacid, 1999; Peippo and Lund, 1994a,b). The many simulation tools developed for designing and simulating BIPV systems can be categorised as:

- Pre-feasibility tools: determine the viability of a BIPV system for a particular application in terms of energy production and the life-cycle cost of the system. 
Table 2

Features of PV System Design Softwares (Bates et al., 1998).

PV f-Chart For design and analysis of PV systems. Estimates monthly average performance of a PV system by calculating total in-plane insolation from horizontal insolation. Array efficiency calculated using cell temperature. Predicts long-term performance from monthly weather data

SOLCEL-II

Uses hourly values of the horizontal and direct normal radiation, ambient temperature, wind speed and in-plane insolation to predict PV output. Maximum power tracking; floating battery; voltage regulator; and temperature degraded efficiency are employed to simulate the hourly performance of the system.

PVWATTS An internet accessible tool that simulates electrical energy output of a grid-connected PV system for US locations

PVSYST

For design and analysis of stand-alone and grid-connected PV systems. Simulates of a PV system using an inbuilt geographical and meteorological database and 3D CAD facility for visualisation and computation of nearby shading; considers losses including temperature losses, mismatch losses, wiring losses and reflection losses with provision for analysis of measured data capable of modelling of grid-connected system with different inverter(s) configurations and different load profiles

PVSOL For design and optimisation of PV systems. Tool has a large PV and inverter manufacturers database, it accepts user defined component specifications; it is applicable to any PV surface inclinations and orientations; it considers shading effects, it considers component specifications, it inverter unit; allows sizing capability of PV and inverter capacity; it considers different load profiles and utility tariff rates and performs economic analysis by considering the system replacement and the investment residual value PVSIM $\quad$ Models PV cells, modules and arrays using I-V characteristics of cells which includes short circuit current, series resistance, shunt temperature. The programme also includes the effect of blocking diode and bypass diodes in array circuits

PVFORM For stand-alone and grid-connected applications. Global horizontal insolation, ambient temperature and wind speed are inputs to this program. The programme also considers a system with an MPP tracker and simulates a power conditioning unit using partial load efficiency

TRNSYS Transient System Simulation is a sequential-modular simulation program that provides dynamic simulation of a PV system. The component models which are either empirical or analytical, describe the component performance with algebraic differential equations. System simulation is performed by interconnecting individual components

ENERGY-10 PV Applicable for a BIPV grid-connected PV system which allows users to study hourly interactions between the building load and the PV array. This tool works with the design software ENERGY-10 and uses TRNSYS simulation programs for simulation of PV systems

PHANTASM Developed for BIPV applications, is an extension of the TRNSYS program and therefore uses TRNSYS subroutines which require PV characteristic parameters, the transmittance of the glazing, absorptance of the PV cells, the electron band gap and NOCT parameters for the simulation

- Sizing tools: determine the optimal size of different components of a BIPV system based on the life-cycle cost and the purpose of the system used (Simones et al., 1984).

- Simulation tools: perform detailed analysis of the behaviour of a system when given the nature and size of the system. These tools are used to investigate the impact of the load profile, verify the system sizing, investigate system performance under typical conditions and provide information regarding the financial and environmental characteristics of the system.

- Open-architecture research tools: these are flexible in nature, offer modification of existing components or addition of new components into the main programme.

Some simulation tools have been developed specifically for PV system modelling as shown in Table 2, such as PVNet (Bishop, 1988); PVNETSIM (Schilla et al., 1997), PVNode (Stellbogen, 1992), PVSS (Goldstein and Case, 1978), RETScreen (Bakos et al., 2003), simPhoSys (Schmitt, 2002), and Renew (Woolf, 2003). General transient solar energy simulation modules such as TRNSYS (Klein et al., 2000) have also been used successfully for BIPV simulation (Mondol et al., 2005, 2006a,b, 2007a). Different simulation tools can:

- Be applicable to a wide range of grid-connected, standalone or hybrid PV systems (Endo and Kurokawa, 1994) Model individual BIPV components (Krenzinger and
Wagner, 1992; Gow and Manning, 1999; Sukamongkol et al., 2002), particularly inverters (Jantsch et al., 1992).

- Provide detailed algorithms to take account of particular aspects of component behaviour; for example low-insolation PV module performance (Smiley and Stamenic, 2002).

- Include different sky radiation models (Louche et al., 1994). The choice of such models can have a significant effect on accuracy of the calculation of insolation on inclined BIPV planes (Mondol et al., 2008). Furthermore the accuracy of different anisotropic (Perez et al., 1990) and isotropic sky models varies seasonally in many locations, though twelve values of monthly mean insolation are adequate for the calculation of annual electrical output (Perpiňan et al., 2008).

- Use measured insolation data (Moser and Inamura, 1994; Park et al., 2001a,b).

- Consider urban site parameters (Snow et al., 1999) including orientation and shading (Caamaño and Lorenzo, 1996; Almonacid, 1995).

- Account for electricity tariffs and building energy loads (Travers et al., 1998; Mondol et al., 2006a).

- Encompass economic factors such as interest rates and relative fixed acquisition costs (Weidele et al., 1996) or environmental, regulatory and policy factors.

\subsection{Viability criteria}

For a BIPV system, the economic viability is determined by the generated electricity cost (i.e., profitability or the 
cash flow implications of the original BIPV investment decision) in competition with that of other (usually grid) electricity (Lazou and Anastassios, 2000; Oliver and Jackson, 2000, 2001). Conventional energy sources usually have small initial costs and relatively large operating costs whereas BIPV systems require higher initial investment costs but smaller operating costs (Goswami et al., 1999). Parameters such as discount rate, escalation rate, inflation rate and system lifetime influence significantly the economic performance of a system. The simple payback period of a BIPV system is calculated from the total investment cost divided by the first year's revenues from grid electrical energy displaced (Bakos and Tsagas, 2002). A more complex realistic payback period is the time at which the initial cost and the annual expenses equals the energy saving cost with compounded interest (Böer, 1978). A PV project is viable economically when the invested capital plus a minimum acceptable rate of return is recovered within a service life shorter than the technical service life (Lasnier and Ang, 1990). Life-cycle cost analysis (LCC) considers all the costs associated with an energy delivery system over its life time and all other future costs or cash benefits, and discounts them to their present value (Duffie and Beckman, 1991). As anticipated future costs are brought back to present costs by calculating how much would have to be invested at a market discount rate to have the funds available when they will be needed (Duffie and Beckman, 1991) it enables comparison of the delivered costs of technologies with different cost structures (Bhuiyan et al., 2000). The life-cycle cost includes both initial capital cost and the year-to-year operating costs of the BIPV system and can be expressed as the sum of capital equipment cost, acquisition costs, operating costs, interest charged on borrowed capital, maintenance, insurance, and miscellaneous charges, taxes, recurring costs associated with the system and salvage value (Goswami et al., 1999). Keoleian and Lewis (1997) presented a life-cycle inventory model to compare the economic performance of BIPV with conventional grid-connected systems. There are differences in the embodied energy of BIPV systems due to different transmission and distribution losses and replacement of conventional building materials: the energy embodied per $\mathrm{kWh}$ of electricity generation for centralised PV, BIPV cladding systems and glass cladding systems have been estimated as $11.4 \mathrm{MJ}, 4.15 \mathrm{MJ}$, and $2.6 \mathrm{MJ}$, respectively (Oliver and Jackson, 2001).

When the payback period of a grid-connected BIPV system is calculated considering variable tariff rates, inclusion of flat-rate net metering and battery storage (where storage supplied energy to the load at the peak load time) the shortest BIPV pay back period ensues for PV energy stored at the off-peak time and sold to the grid at peak times (Khouzam, 1997). For favourable discount rates, low operation and maintenance expenses and high insolation sites, Chabot (1998) estimated a PV electricity cost of $0.122 \mathrm{SkW} \mathrm{h}^{-1}$, this was close to prevailing domestic electricity tariffs. Often, however, the breakeven cost of a PV system remains dependent on the electrical load (Nishikawa et al. 1992), this can vary significantly with occupancy and building characteristics both in non-domestic and domestic buildings (Yohanis et al., 2008). From a utilities' viewpoint the cost of BIPV electricity depends on its capacity to meet peak demand. Saving peak load demand removes the need for capital, and recurrent investment in auxiliary energy systems such as expensive gas turbines or hydro storage. For a BIPV system, this presents an opportunity to maximise economic performance by saving peak building-load demand (Koner et al., 2000). Effective demand saving depends on load profiles, available insolation and peak demand tariff rates all being appropriate. In warm-climates, peak load demands occur generally on hot sunny days when to air-conditioning electricity usage coincides with the most productive period of BIPV electricity generation. For a system with no storage, this occurs when BIPV output matches with the utility or the building's peak load. A BIPV array connected via power conditioning equipment to the building's distribution panel is referred to as 'non-dispatchable' because it has no battery storage and so energy flow from the system is not managed to meet peak demand. Peak saving occurs when system output coincides with the building peak load demand. The peak saving of a BIPV system is influenced primarily by two factors: (i) significant fluctuations in capacity factor and (ii) an uncertain match between solar irradiance and daily building peak load. When the peak BIPV output and peak load do not match closely, the use of storage could improve peak saving benefits (Byrne et al., 1996). Control units have been developed to optimise load matching by managing energy flow from the BIPV system to the load through battery storage (Palomino et al., 1997). These control units supply energy to the building load during the peak load times and direct BIPV energy into storage at off-peak periods. Frei et al. (1997) found that the average percentage of maximum output with respect to daily load reached close to daily peak load for a system with $1.25 \mathrm{~h}$ of storage showing the advantage of using a storage system for reduction of peak load demand.

A study into PV supply and load demand considering different weekdays and weekend load patterns (Rahman et al., 1990), showed that the PV supply and load demand generally matched well, however, in winter peak PV generation hours fell short of the peak load demand of the building due to short sunshine duration. Conversely if the grid voltage increase due to PV power flow is close to the upper voltage bound of the power distribution line's control range, it would be necessary to restrict PV output (Ueda et al., 2006). If the electricity buying and selling prices are the same, then consumers will not benefit by changing their load profile (Haas, 1994). If the selling price is less than the buying price consumers will benefit by shifting their on-peak load dernand to the peak PV supply, alternatively if the buying price is greater than the selling price consumers will gain more by selling more electricity to the grid by shifting PV peak supply to the off-peak load 
demand times with energy storage and flow management (Mondol et al., 2006b).

\subsection{Balance-of-systems costs}

Module array frames, electrical cables, DC-AC inverters, regulators, switch gear, batteries and safety equipment are referred to as balance of system (BOS) components. BOS costs are typically half of the total system cost (Roberts et al., 2001) and the area-related BOS costs increases as the PV efficiency decreases (Whitaker and Real, 1999). To reduce the total system cost and hence the unit cost of BIPV generated electricity it is vital to reduce both BOS and PV module manufacture costs. Reduced BOS costs can be achieved through simplification of the installation process to minimise labour, standardisation of components to reduce inventory and training complexity and increasing cell efficiency. As an example of the latter, a $20 \%$ efficient module requires only half the area, support structures and cabling required for a $10 \%$ efficient product. By the end of year 2000 some 200 retail gas station canopies in 9 countries had been fitted with $18 \mathrm{~kW}_{\mathrm{p}}$ to $40 \mathrm{~kW}_{\mathrm{p}}$ PV installations; in the course of installing the first 100 systems, installation unit cost halved through design and components standardisation building integration and common installation procedures (Roberts et al., 2001).

Material choices and component design can improve significantly BIPV efficiency and longevity. Ethylene vinyl acetate co-polymer is now the common encapsulant material as it suffers no discolouration due to moisture absorption that ensued in early modules that used polyvinyl butyralate. Near-surface protection is typically a multilayer film of Ted$\mathrm{lar}^{\circledR}$ and polyester. Polyester has largely replaced aluminium as the moisture barrier layer as aluminium had a tendency to cause short-circuits in cell strings (Roberts et al., 2001). Larger module dimensions have reduced the cost of both noncell components in the module and installation. Terminal boxes are being replaced with flying leads and weather-proof in-line plugs and sockets to reduced significantly on-site installation costs (Roberts et al., 2001).

\section{Optical solar energy concentrators for BIPV}

The cost of wide-scale implementation of BIPV as a building façade cladding can be reduced by substitution of some of the expensive photovoltaic materials by lower cost concentrating systems (Zacharopoulos et al., 2000; Eames et al., 2000; Gajbert et al., 2007; Bowden et al., 1993, 1994). Either trapping light within screen-printed solar cells (Green, 1995) or using reflective/refractive devices to increase the luminous power flux onto the solar cell surface (Luque et al., 1995) ensures that solar cells convert the additional power incident without significant loss of efficiency. Static parabolic trough concentrators for different receiver locations have been reported for photovoltaic applications (Kabakov and Levin, 1994). Practical non-imaging concentrators (Winston, 1974, 1975; Welford and Winston, 1979; Winston, 1980; Leutz et al., 1999b, 2000; Winston and Hinterberger, 1995) are designed with one or two pairs of acceptance half-angles that accept diffuse insolation. Concentrated solar fluxes are thus non-uniform with the diffuse fraction contributing to flux distributions at the absorber in non-imaging solar concentrators with low concentrations typically employed in stationary BIPV systems (Gajbert et al., 2007; Rabl, 1985). Non-imaging systems can be made either by using a refracting lens or by using reflective mirrors (Boes and Luque, 1992). Compound parabolic concentrators (CPC), (Welford and Winston, 1978), concentrate the radiation from the aperture to the receiver and can significantly increase the electric power yield for a unit area of PV. Because of its wide angle of acceptance, the CPC can modestly concentrate solar energy without diurnal tracking of the sun (Brogren et al., 2001), and therefore can reduce the PV cell area required decreasing the cost of PV generated electricity.

The concentration ratio determines the increase in relative radiation at the surface of the exit aperture/absorber. The geometrical concentration ratio is defined as the ratio of the area of aperture to the area of the receiver (Duffie and Beckman, 1991). The optical concentration ratio indicates the proportion of incident rays within the collecting angle that emerge from the exit aperture (Winston, 1980; $\mathrm{Rabl}, 1976 \mathrm{a})$. A CPC can be designed for different absorber shapes giving rise to a range of different reflector designs. For the CPC with a tubular absorber, detailed parametric and experimental analyses of optics and heat transfer have been undertaken (Eames and Norton, 1993a,b, 1995; Eames et al., 1999). Models can predict performance accurately for changes in geometry reflectance, emittance or thermal conductivity, and incident insolation intensity and distribution (Eames et al., 1999). A refractive threedimensional symmetric CPC has been employed as a concentrator for photovoltaics (Brunotte et al., 1996). Asymmetric compound parabolic concentrator designs have been reported (Rabl 1976a,b; Smith 1976; Mills and Giutronich 1978, 1979; Winston and Welford 1978; Blanco et al., 1986; Mullick et al., 1987; Kienzlen et al., 1988; Norton et al., 1991; Zacharopoulos et al., 2000; Adsten 2002 and Mallick et al., 2002a,b). An ideal extreme asymmetric concentrator (EAC), (Smith, 1976), collects solar energy within the maximum acceptance half-angle at a fixed concentration. However, the long second reflector leads to a large number of reflections being required for rays to reach the receiver, which leads to higher optical losses and lower optical efficiency. In a subsequently developed EAC (Mills and Giutronich, 1979), the mirror was located relatively close to the receiver providing a larger acceptance angle for rays reflected from the mirror, reducing the number of reflections. This allows an increase in aperture area which compensated for losses due to rays passing through the gap between the receiver and mirror (Winston and Welford, 1978). 'Sea shell' asymmetric concentrators (Rabl, 1976b) are shown in Figs. 10 and 11. The system in Fig. 10 


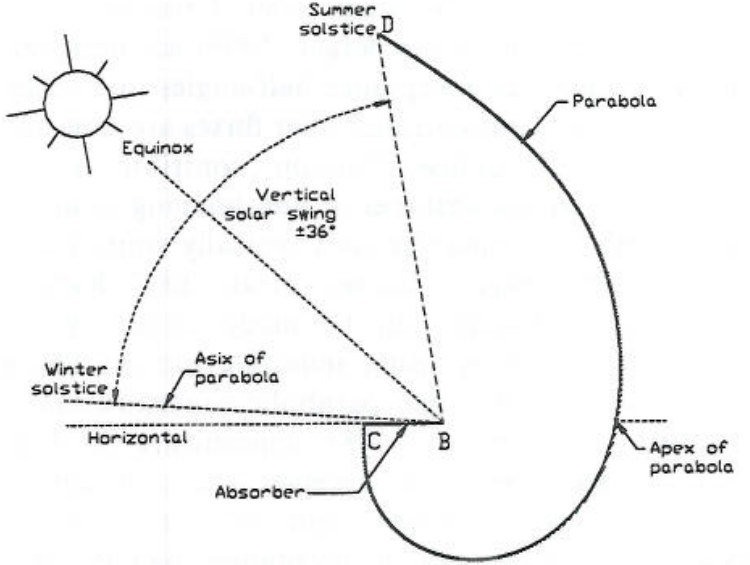

Fig. 10. Stationary 'Sea Shell' collector with variable concentrations, with maximum output in the summer (Rabl, 1976b).

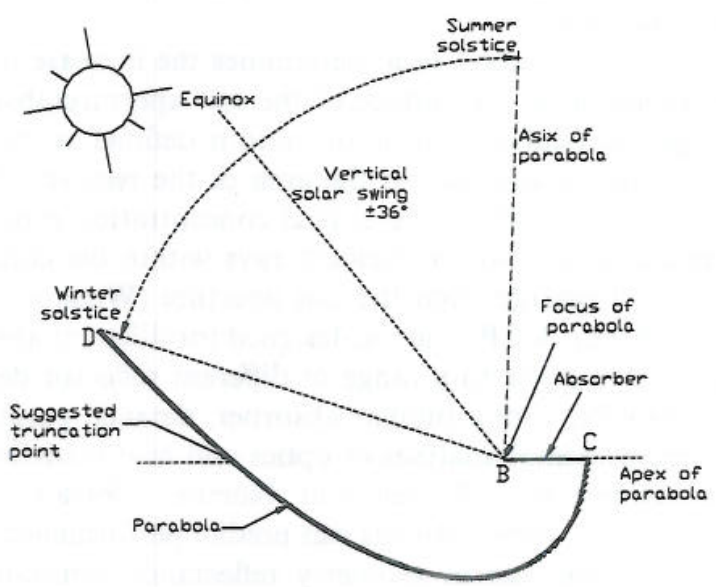

Fig. 11. Stationary 'Sea Shell' collector with variable concentrations, with maximum output in the winter (Rabl, 1976b).

was designed for maximum output in summer and has an acceptance half-angle of $36^{\circ}$ providing a collection time of $7 \mathrm{~h}$. The system in Fig. 11 was designed to achieve maximum output in winter. The "Maximum Reflector Collector" (MaReCo) was characterised experimentally for high-latitude bi-facial cell BIPV applications (Adsten, 2002). Different MaReCo configurations were made for stand-alone, roof integrated, east/west, spring/fall and wall integration. A cross-section of a stand-alone $\mathrm{MaReCo}$ is shown in Fig. 12 (Adsten, 2002). Fig. 13 illustrates that the cross-section of roof integrated MaReCo designed for Stockholm conditions (Adsten, 2002). The highest optical efficiency reported was $56 \%$ for a bi-facial based MaReCo. In contrast, optical efficiency of $91 \%$ was predicted for dielectric-filled BIPV covers (Zacharopoulos et al., 2000) and $85 \%$ for an air-filled asymmetric CPC BIPV system (Mallick et al., 2002a).

A novel non-imaging asymmetric compound parabolic photovoltaic concentrator (ACPPVC) was designed, constructed and experimentally characterised (Mallick et al., 2004a) for BIPV applications. The use of this ACPPVC

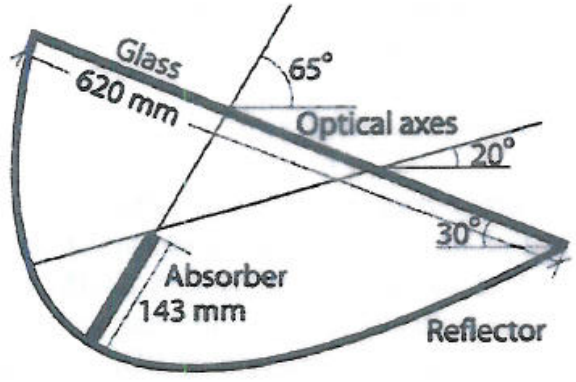

Fig. 12. Section of the stand-alone MaReCo for Stockholm conditions. Aperture tilt $30^{\circ}$. Optical axes $20^{\circ}$ and $65^{\circ}$ defined from the horizon (Adsten, 2002).

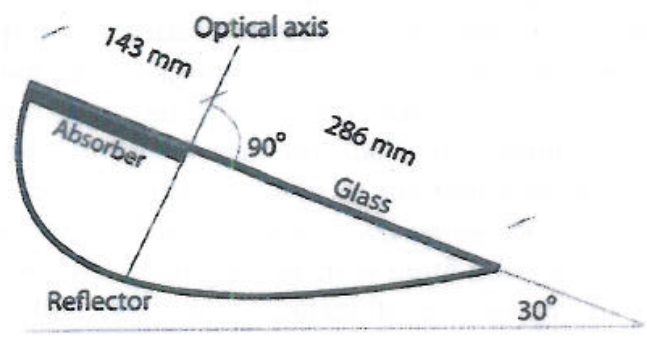

Fig. 13. Section of a roof integrated MaReCo design for a roof angle of $30^{\circ}$. Optical axis perpendicular to the cover glass (Adsten, 2002).

increased the maximum power by $62 \%$ (i.e. the power by a factor of 1.62) when compared to the same PV system without concentrating elements (Mallick et al., 2004b) for a designed geometrical concentration ratio of 2 . The performance was less than that anticipated due to increased back plate temperatures which were on average $12^{\circ} \mathrm{C}$ higher (Mallick et al., 2006) and ohmic losses in interconnections between the solar cells.

Non-imaging Fresnel lens concentrators for medium concentration photovoltaic applications have been designed, manufactured and a comparative cost analysis reported (Leutz et al., 1999a,c). A truncated non-imaging Fresnel lens was analysed using a ray trace analysis (Welford, 1978) for minimal optical aberration. Variable acceptance half-angle pairs have been designed for use with a non-imaging Fresnel lens applicable to BIPV (Leutz et al., 2000). The optical concentration ratio undergoes a sharp decrease once the incidence angle exceeds the design acceptance half-angle. A non-imaging static concentrator lens was developed for the conditions in Sydney, Australia utilising refraction and total internal reflection to give a geometrical concentration ratio of 2.0 and a lens efficiency of $94 \%$ (Shaw and Wenham, 2000). The annual averaged optical concentration ratio was 1.88 for direct insolation within $\pm 60^{\circ}$ and $\pm 25^{\circ}$ in the East-West and North-South directions, respectively. A "flat plate static concentrator" with optical efficiencies of $87.6 \%$ and $85.6 \%$ was reported for mono-facial and bi-facial cell BIPV applications (Uematsu et al., 2001a). It was reported that $90 \%$ of the annual irradiation could be collected by the mono-facial 
system with a concentration ratio of 1.5 and the bi-facial system with a concentration ratio of 2.0 (Uematsu et al., $2001 \mathrm{~b}$ ). Optical efficiencies of $94.4 \%$ (Uematsu et al., 2001c) based on a two-dimensional raytrace programme were reported for the FPSC system with a prism array. The front and rear illumination efficiencies were reported to be $15 \%$ and $10.5 \%$, respectively (Uematsu et al., 2003). However, Uematsu et al. (2001a-c) did not take into account the effect of increased temperatures on the photovoltaic solar cells conversion efficiency. Static concentrators, as shown in Fig. 4, offer a compromise between high concentration systems that require tracking and non-concentrating flat-plate modules (Bowden et al., 1993). A "slimline" design was reported to achieve a concentration ratio of four (Wenham et al., 1995). Thermal analysis indicated that performance loss through additional heating of the PV was more than offset by the gains achieved through concentration. The efficiency of the module was reported to be $15 \%$ greater than that of the flatplate module (Wenham et al., 1995). $\mathrm{Cu}(\mathrm{In}, \mathrm{Ga}) \mathrm{Se}_{2}$ solar cells with low concentration compound parabolic and plane reflectors for low concentration photovoltaic applications (Wennerberg et al., 2000; Brogren et al., 2003) showed a maximum electric power increase of 1.9 times with a fill factor decrease from 0.6 to 0.5 when compared to cells without the concentrator (Brogren et al., 2003).

Dielectric non-imaging concentrating covers for PV integrated building façades use total internal reflection within the dielectric material to provide optimal optical efficiency (Shaw and Wenham, 2000; Zacharopoulos, 2001; Korech et al., 2007). A three-dimensional optical analysis has showed that an asymmetric concentrator design is more suitable for building façade BIPV compared to a symmetric concentrator. Both asymmetric and symmetric concentrators had an optical efficiency of $81 \%$ for a wide range of solar incidence angles. The asymmetric concentrator maintained optical efficiencies of over $40 \%$ even for incidence angles outside its two-dimensional angular acceptance range. The comparative energy collected by a symmetric dielectric concentrator and a flat-plate cover are shown in Fig. 14 (Zacharopoulos et al., 2000).

Photovoltaic Facades of Reduced Costs Incorporating Devices with Optically Concentrating Elements (PRIDE) technology incorporating 3 and $9 \mathrm{~mm}$ wide single crystal silicon solar cells showed excellent power output compared to a similar non-concentrating system when it was characterized indoors using both a flash and continuous solar simulator. However, durability and instability of the dielectric material occurred under long term outdoor characterisation when the concentrator was made using casting technology. For large-scale manufacturing, durability and to reduce the weight and cost of the concentrator, second generation PRIDE designs utilise $6 \mathrm{~mm}$ wide solar cells at the absorber of dielectric concentrators. Injection moulding was used to manufacture $3 \mathrm{~kW}_{\mathrm{p}}$ of $\mathrm{PV}$ concentrator modules with the PRIDE design suitable for building façade integration in Europe. PV concentrator modules achieved a power ratio of 2.01 when compared to a similar non-concentrating system. The solar to electrical conversion efficiency achieved for the PV panel was $10.2 \%$ when characterised outdoors. In large-scale manufacturing, a module cost reduction of over $40 \%$ is potentially achievable using this concentrator technology (Mallick and Eames, 2007). A prototype photovoltaic concentrator array called Euclides of $60.4 \mathrm{~m}^{2}$ has been built using reflecting linear optics maintained in focus by horizontal single-axis tracking (Sala et al., 1996). The results from the Ecluides prototype showed a clear cost advantage with respect to flat modules. Efficiencies of $17 \%$ under $5 \times$ concentration have been achieved (Bruton et al., 2002).

\section{Luminescent solar energy concentration for BIPV}

\subsection{Operating principle}

For large-scale building façade BIPV applications lowcost non-tracking solar energy concentrators are required. The concentration restriction limits of non-tracking nonimaging optical systems, due to phase space conservation (Welford and Winston, 1979) do not apply to luminescent solar concentrators (LSC) (Goetzberger et al., 1985). A LSC illustrated in Fig. 15 consists of a transparent flat sheet of glass or plastic doped with fluorescent dyes for example Rhodamine 6G; Rhodamine B; Ruthenium byridyl and crystal violet. Light impinging on the surface of the concentrator is partly refracted into the fluorescent material and after absorption by the dye molecules; photons are re-emitted isotropically at a lower frequency (Zastrow et al., 1981; Goetzberger et al., 1985). The amount of photons depends on the absorptivity and on the fluorescence quantum yield (QY) ratio of the number of photons fluorescing to the number of photons incident on the material. If the probability of emission is equal in all directions, part of the emitted photons will leave the medium and part will be reflected back at the surface of the medium. Since the refractive index of the layer is much higher than that of the external medium (air), a large proportion of the emitted photons will be trapped within the plate and transported by total internal reflection (TIR) to the edges. Reflectors are mounted on three of the edges and on the back surface, so light can only emerge along the fourth edge where it is absorbed by PV cells. These mirrors reflect light that may be incident on these surfaces outside the angular range for TIR. On their way to the edges, re-absorption (due to the overlap of the absorption and emission spectra) and light scattering (due to material and surface inhomogeneities) may take place. Absorption by the carrier material will also occur. A large Stokes shift, that is the ratio of the average energy of emitted photons to the average energy of the absorbed photons, will avoid self-absorption increasing the output of the concentrator (Markvart et al., 2005).

These concentrators in BIPV applications are the capability to (i) concentrate diffuse radiation as well as direct without tracking, by concentrating incident radiation from every direction, (ii) separate the solar spectrum into two or 


\section{ARTICLE IN PRESS}

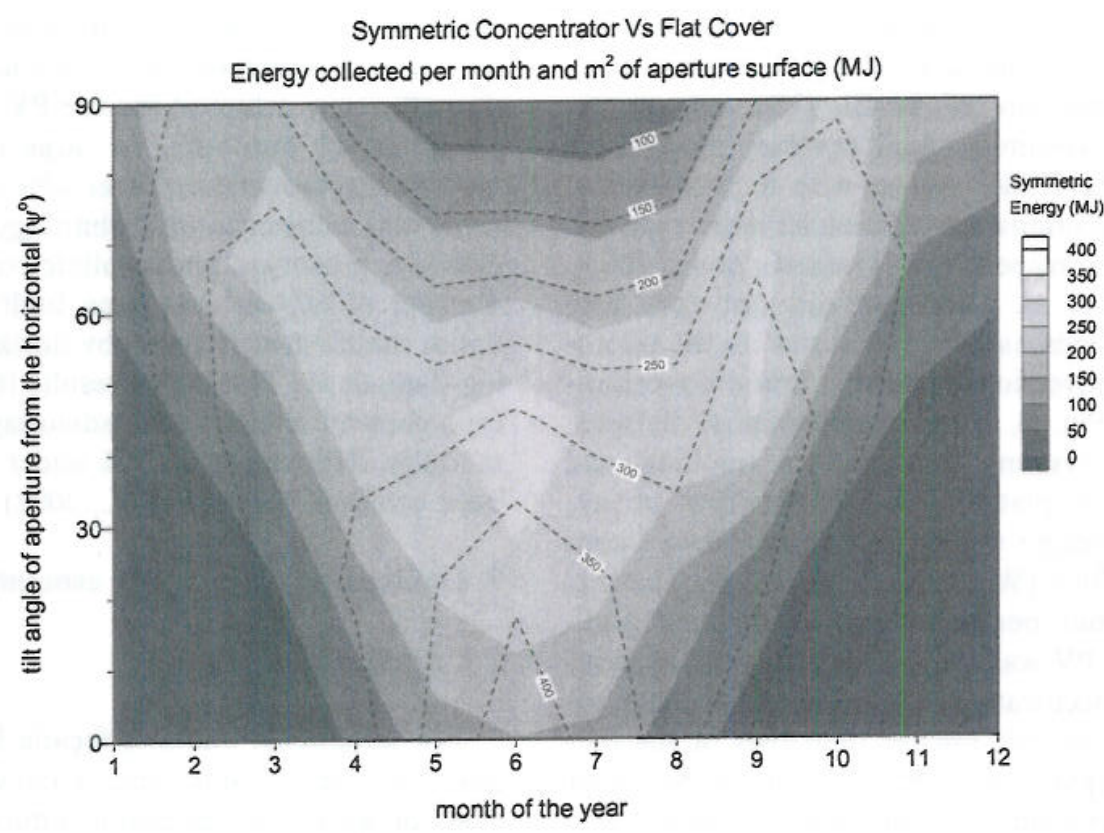

Fig. 14. Energy collected per month and $\mathrm{m}^{2}$ of the aperture surface for the symmetric concentrating (flood) and the flat (dashed line) covers against the tilt angle $\psi$ from the horizontal. The covers are located in London, UK $\left(52^{\circ} \mathrm{N}\right)$ and facing south $\left(\gamma=0^{\circ}\right.$ and $\left.\beta=0^{\circ}\right)$ (Zacharopoulos et al., 2000).

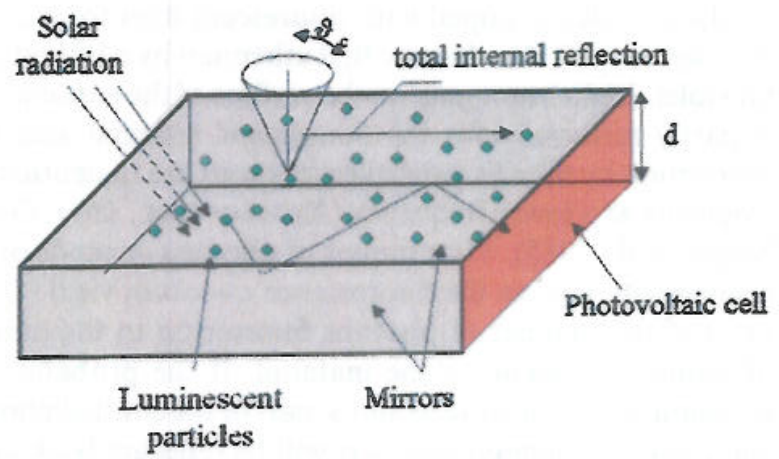

Fig. 15. A luminescent solar concentrator.

more parts, each of which may be converted to electricity with greater overall efficiency using different solar cells (Reisfeld and Jorgensen, 1982), (iii) when compared with geometric concentrators heat dissipation problems are reduced, and (iv) if the luminescent concentrator materials are of lower cost than the displaced PV, then the cost of BIPV electricity is lower.

The energy lost in shifting incident photons to longer wavelengths is distributed throughout the absorbing region of the converter as in the longer wavelength infrared radiation (Rapp and Boling, 1978). A LSC aims to shift the solar spectrum by fluorescence to a wavelength region where the specific solar cell response is higher (Goetzberger and Greubel, 1977; Rapp and Boling, 1978; Goetzberger and Wittwer, 1979). Panel efficiency is a function of dopant concentration and sheet thickness (Taleb, 2002).

\subsection{Dye luminescent solar concentrator}

Many fluorescing dyes have been synthesised with a great number available for textiles, advertising, scintillators or dye lasers, though the dyes used for fluorescent energy conversion require different properties. As many dye molecules have QYs close to $100 \%$ (e.g., Rhodamine 6G) and most of them operate in the UV and blue range of the spectrum, QY does not appear to be a serious barrier. Measurements have shown lower QYs for dyes fluorescing in the red and infrared regions where the silicon solar cells has its maximum sensitivity (Wood and Long, 1978; Kondepudi and Srinivasan, 1990), however, QY is improving (Jung et al., 2001). For an ideal LSC, the absorption and emission spectra should be well separated.

A stack of sheets doped with different dyes to match different luminescent wavelengths, demonstrated in Fig. 16a and b using LSCs as beam splitters can be coupled to PV cells with optimum sensitivities in different spectral ranges, (Goetzberger and Greubel, 1977). The main advantage of using a stack is that the concentrated light from individual collectors can then be transformed by correspondingly spectrally-optimised solar cells, with a higher overall efficiency (Reisfeld and Jorgensen, 1982) than can be expected with a single plate. The multi-stack device consists of several plates; the top plate absorbs the shortest wavelength radiation, which is then emitted as longer wavelength fluorescence. The consecutive total reflections transport this light to a PV cell with a relatively high-energy gap. The lower plates absorb at increasing wavelengths and their luminescent species emit further down in the red or infrared (Wittwer et al., 1984). An advantage of multi-stack LSC is that approximately half 


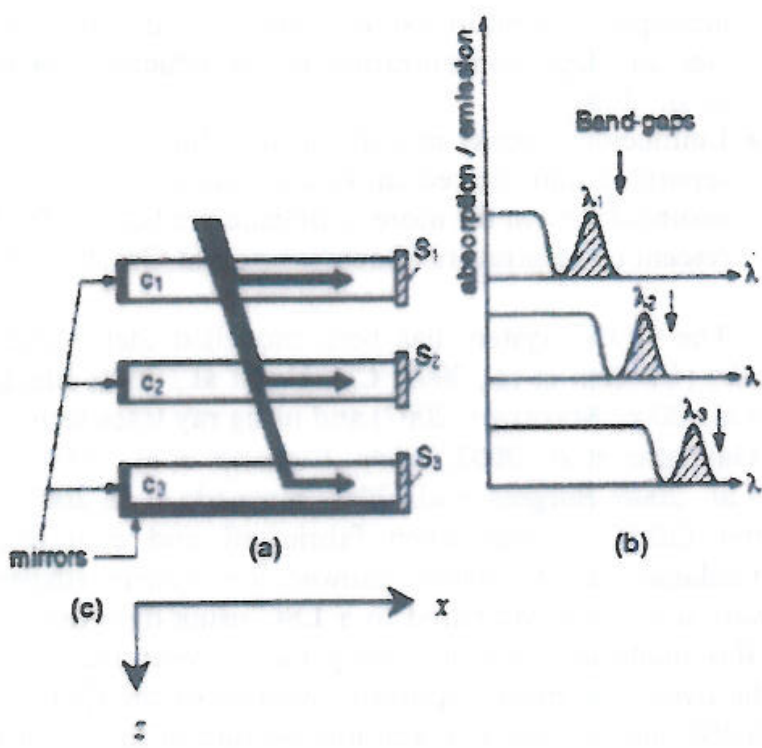

Fig. 16. A schematic of a stack of three collectors (c1-c3) with three solar cells (s1-s3) in series (a). The absorption and emission spectra of the molecules in the collectors (b) (Goetzberger, 1978).

of the radiation emitted within the critical cone can be recovered by the next plate below as in Fig. 16b. A narrow air gap between the upper plate and the second plate is necessary to prevent luminescence in the upper plate penetrating into the lower plate and becoming absorbed. It is impracticable to make stacks of more than three plates (Reisfeld and Jorgensen, 1982) and that it is probable that two plates is often optimal. In a multilayered structure the physical separation of chemically active species improves dye stability and better control over dye concentration, higher optical density can be obtained by building up multiple layers of the same dye (Hermann, 1982).

A thin film fluorescent concentrator consists of a film of $\sim 1 \mathrm{~mm}$ thickness deposited on an undoped optically transparent substrate several millimetres thick (Friedman, 1981) in which absorption and emission by the dye occur in the thin film rather than throughout the glass or plastic substrate. The advantage of thin films having optical contact with a transparent thicker plate is that the fluorescence emitted from the dyes in the thin film is trapped in the entire film-substrate composite and thus the parasitic losses due to self-absorption and scattering from impurities can be reduced greatly compared to bulk doped plates (Reisfeld et al., 1988). In order for trapping to be efficient in the composite (as opposed to trapping in the thin film alone), the refractive index of the film should be either slightly less than or the same as that of the substrate, (Grande et al., 1983). The thin film approach allows a dye-doped film to be deposited on glass as well as plastic substrates. Because of the higher dye concentrations in the thin film, efficient energy transfer might also be achieved between co-doped dyes. Finally, if a glass substrate is used, it can also be doped with inorganic ions, thereby, shielding the dyes from UV radiation while at the same time pumping them fluores- cently (Friedman, 1981). A glass-plastic hybrid system may be made by combining dyes which absorb in the visible spectral region with luminescent glasses absorbing in the UV and IR region of the spectrum.

For a solar energy conversion, high UV chemical stability is required, but under UV irradiation dyes decompose (Mansour, 1997, 1998; Mansour et al., 1998 and Salem et al., 2000). In solar collector applications this may be prevented by using a filter to exclude UV wavelengths. After $200-400 \mathrm{~h}$ of continuous exposure to radiation, a reduction of $15-20 \%$ was observed in the optical density and intensity of the luminescence of polymer plates with Rhodamine 6G, Coumarin and other luminophors (Batchelder and Zewail, 1979; Wittwer et al., 1984). Overlap of absorption and emission spectrums competes with the escape of the fluorescence and lowers the QY. Even when absorption and fluorescence bands are separated in liquid solutions, they exhibit a large overlap in a rigid medium such as films containing dyes. The effect of self-absorption may be reduced by adding polar molecules of high mobility to the dye before forming the thin film (Taleb, 2002). Such mixing allows for better separation between absorption and fluorescence bands and hence increases the LSC efficiency.

\subsection{Quantum dot solar concentrator}

Quantum dots (QD) (Reed, 1993) are man-made nanostructures that typically vary from tens to hundreds of nanometers in size (Gerion et al., 2001). These dimensions are of the order of the electron de Broglie wavelength and so electrons confined in these low dimensional semiconductor structures exhibit electronic and optical characteristics similar to those in atoms (Akkermans et al., 1995; Weinmann, 1997; Banyai and Koch, 1993). Due to these quantum size effects, both the absorption spectrum and the emission spectrum of semiconductors shift to higher energies with decreasing particle size away from the red end of the spectrum, as the crystallite becomes smaller; Fig. 17 illustrates the spectral shift with size, for cadmium selenium (CdSe) QDs, (Sattler, 2002). The occurrence of such a redshift in the emission spectrum relative to the absorption spectrum is seen in QDs of $\mathrm{Si}, \mathrm{CdSe}$, InP and In $\mathrm{GaAs}$ and exists irrespective of the preparation methods of the dots (Fu and Zunger, 1996). The redshift arises from the size distribution in dot samples: the larger dots in a sample have lower band-edge energies so if the sample is excited with sufficiently high-energy photons above the band edge of the smallest dot, the emission will be redshifted because it results from the deexcitation of band edges of all the dots in the sample (Fu and Zunger, 1996). QDs are capable of absorbing light over an extremely broad wavelength range as illustrated in Fig. 18 which depicts the absorption spectra of InP QDs. The absorption spectra illustrates the spectral shift to higher energy as QD size decreases (Micic et al., 1998).

In a Quantum Dot Solar Concentrator (QDSC) the fluorescent dyes are replaced by quantum dots (QDs). Insola- 


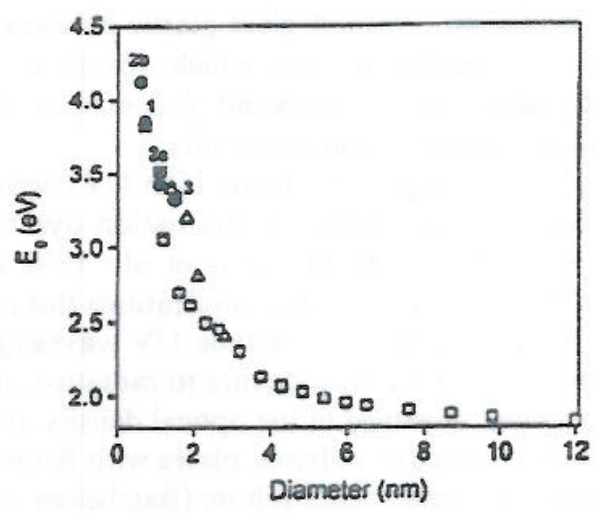

Fig. 17. Size dependence of bandgap of CdSe particles (Sattler, 2002).

tion absorption by a QD leads to the emission of lower frequency photons; the number that is emitted depends on the carrier material absorptivity and the QD quantum effciency. As in an LSC with dyes, emitted photons may leave the carrier material or be reflected at the device surface to remain within the concentrator. If the refractive index of the carrier material is higher than that of the surrounding medium (in this context, air), a large proportion of the emitted photons will reach the edges by total internal reflection. The asserted advantages of $\mathrm{QDs}$ over dyes are:

- QDs are nanometer sized crystalline semiconductors and degrade less than organic dyes.

- High fluorescence QY has been observed in QDs at room temperature (Blanton et al., 1996; Alivisatos, 1998).

- The absorption threshold can be tuned by choice of dot diameter. Colloidal InP QDs have thresholds which span the optical spectrum (Micic et al., 1997).

- Red shift between absorption and luminescence is determined primarily by the spread of dot sizes, which in turn can be optimised by choice of growth conditions. Re-

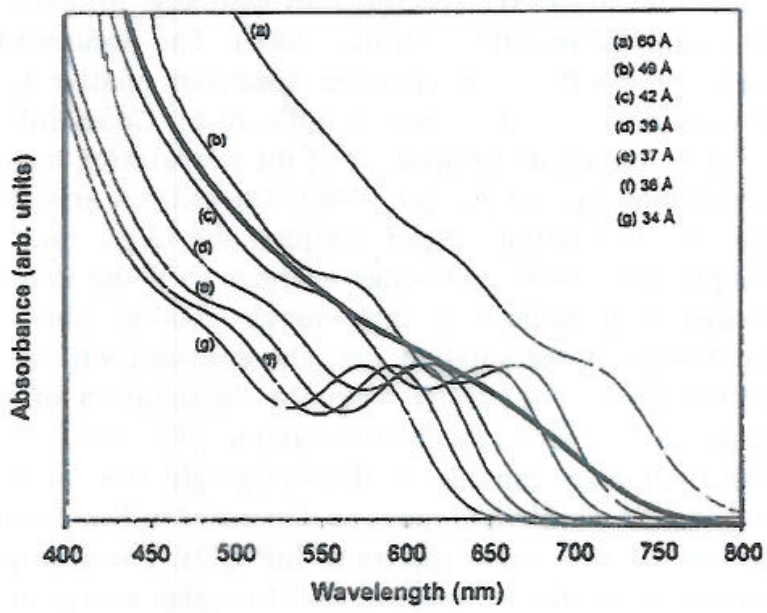

Fig. 18. Absorption spectra of InP QDs after the initial colloidal preparation (bold line) and after size selective precipitation (spectra for QD sizes of $26-60 \AA$ ) (Micic et al., 1998). absorption therefore can be minimised and high efficiencies and high concentration ratios achieved (Barnham et al., 2000).

- Luminescent peaks and absorption thresholds are well separated and the red shifts are comparable with those assumed even in the more optimistic predictions for fluorescent concentrators (Goetzberger and Greubel, 1977).

The QDSC systern has been modelled thermodynamically (Chatten et al., 2003; Chatten et al., 2006; Markvart et al., 2006; Markvart, 2007) and using ray trace techniques (Gallagher et al., 2002, 2004a; Richards et al., 2004; Slooff et al., 2006; Burgers et al., 2006; Kennedy et al. 2007). The first QDSC system when fabricated and characterised (Gallagher et al., 2004b) showed low system efficiencies were low when compared to a LSC using dyes due to the QDs quantum efficiency being much lower than that of the dyes. The most important features of the QD for the QDSC are the high QY and low overlap of the absorption and emission bands. If $\mathrm{QDs}$ with $>0.99 \mathrm{QE}$ can be incorporated into a suitable transparent media then QDSCs which perform in the upper range of efficiency predicted for dye concentrators may be realised, (Gallagher et al., 2007a,b).

Building from previous work on the LSC and replacing dyes with QDs a range of designs have been studied, in flatplate design (Barnham et al., 2000; Chatten et al., 2003; Gallagher et al., 2002; Gallagher et al., 2004a,b; Gallagher et al., 2007a,b; Barnham et al., 2006; Rowan et al., 2006; Reda, 2008) stacked plates (Farrell et al., 2006) different geometries (Rowan et al., 2007; Kennedy et al., 2007) and thin films (Schüler et al., 2007). The use of photonic layers (Goldschmidt et al., 2006) to trap the absorbed incident radiation and the use of passive luminescence layers (van Sark et al., 2004; van Sark, 2006) for up-conversion (Richards, 2006) and down-conversion (Shalav et al., 2007) have been investigated. In each case a layer above the solar cell is designed to absorb photons outside the cell bandgap and emit within the cell bandgap. This requires a broad-band absorption from the dye or QD and $100 \%$ efficiency (or transparency) in spectral regions close to the band edge. Mixing dyes and using different size distributions of QDs could broaden absorption QDs embedded in dielectric layers directly above traditional devices might readily add $3-5 \%$ to device efficiency with little extra cost (van Sark,'2006). Commercially-available QDs do not presently have a high enough QY to enable a highly efficient device to be fabricated (Gallagher et al., 2004a,b, 2007a,b; Sholin et al., 2007, however, NIR QDs do show promise for this application (Kennedy et al., 2009)).

\section{Thermal management of BIPV}

\subsection{Thermal effects on BIPV conversion efficiency}

Only a part of the solar energy spectrum absorbed by a PV material is converted into electrical energy, the rest is converted into heat, resulting in increased solar cell temper- 
ature. Module temperature is a function of ambient temperature, the thermal properties of module encapsulation materials and the thermal effects of the mounting structure. When the cell temperature increases, the band gap in the junction is reduced and therefore more photons are able to participate in electron-hole pairing causing reduction of the direct band gap (Fahmy, 1998) thereby diminishing electricity production. The photocurrent though increasing slightly with increasing operating temperature due to band gap shrinkage (and associated expansion of the photoresponse spectrum to longer wavelengths) will not be sufficient to compensate for the drop in the open circuit voltage $V_{\text {oc }}$ and fill factor (FF) of the I-V characteristic due to the saturation current rising exponentially with temperature (Andreev et al., 1997). Increasing temperature therefore reduces the available potential difference across the junctions to drive the desired forward current. The relationship between temperature and efficiency varies with cell material. For a crystalline silicon module, the power output decreases by approximately $0.4 \% \mathrm{~K}^{-1}$, whereas for a-Si this value is approximately $-0.1 \% \mathrm{~K}^{-1}$ (Bücher, 1997). In crystalline silicon solar cells for each $1 \mathrm{~K}$ rise in cell temperature, the open circuit voltage decreases by $\approx 2 \mathrm{mV}$ and cell output power decreases by $0.4-0.5 \%$, respectively, from a base of $25^{\circ} \mathrm{C}$ (Fahmy, 1998; Krauter et al., 1994; Batagiannis and Gibbons, 2001). The temperature effect on cell operation is shown in Fig. 19 (Markvart, 1994). PV current output is relatively stable at higher temperatures, however, the voltage is reduced, leading to a reduction of solar to electrical conversion efficiency as the cell temperature is increased (Ingersoll, 1986; Cross et al., 1994). The thermal properties of PV elements are reported in terms of thermal resistance (Fuentes and Roaf, 1997). The temperature of the PV element can be calculated by (Watt et al., 1998a,b, 1999).

$T=(1-\eta) I R$

where the thermal resistance $R$ has measured values shown in Table 3. Protecting electronic modules from excessive temperatures may be accomplished by: (i) active cooling systems, such as a.ir-conditioning, requiring $\mathrm{AC}$ power and high levels of maintenance; (ii) assisted systems, such as air-to-air heat exchangers, which use DC power, but require less maintenance than the active system; (iii) maintenance free passive systems requiring no power (Prudhoe and Doukas, 1990; Ghiraldi, 1988) and/or (iv) removing and storing the excess heat from the PV cells using phase change material (PCM) (Huang et al., 2004, 2006a,b, 2007; Hasan et al.,2007a,b).

\subsection{BIPV thermal management using phase change materials}

A material undergoing a phase change absorbs or releases latent heat at a relatively constant temperature, PCMs can be used in thermal management schemes where heat input/dissipation is periodic, or is a sudden transient

Table 3

Thermal resistance of different building integrated PV element.

\begin{tabular}{|c|c|c|c|}
\hline & & Type of BIPV system & Reference \\
\hline \multirow{11}{*}{$\begin{array}{l}\text { Thermal } \\
\text { resistance } \\
\mathrm{R}\left(\mathrm{KW}{ }^{-1} \mathrm{~m}^{2}\right)\end{array}$} & 0.031 & Roof integrated & Schmid (1992) \\
\hline & 0.022 & $\begin{array}{l}\text { Free standing } \\
\text { module }\end{array}$ & Schmid (1992) \\
\hline & 0.052 & $\begin{array}{l}\text { Roof integrated } \\
\text { modules }\end{array}$ & DeGheselle (1997) \\
\hline & 0.032 & $\begin{array}{l}\text { Vertical } \\
\text { rainscreen cladding }\end{array}$ & Wilshaw et al. (1995) \\
\hline & 0.035 & $\begin{array}{l}\text { Northumberland } \\
\text { ventilated façade }\end{array}$ & Wilshaw et al. (1997) \\
\hline & 0.042 & Façade & Nordman et al. (1997) \\
\hline & 0.024 & Roof & Nordman et al. (1997) \\
\hline & 0.042 & $\begin{array}{l}\text { Flue ventilated } \\
\text { shingles }\end{array}$ & Okuda et al. (1994) \\
\hline & 0.05 & Closed flue & Okuda et al. (1994) \\
\hline & 0.041 & $\begin{array}{l}\text { Ventilated roof } \\
\text { integrated }\end{array}$ & Laukamp et al. (1995) \\
\hline & 0.066 & $\begin{array}{l}\text { Non-ventilated } \\
\text { façade integrated } \\
\text { modules }\end{array}$ & Laukamp et al. (1995) \\
\hline
\end{tabular}

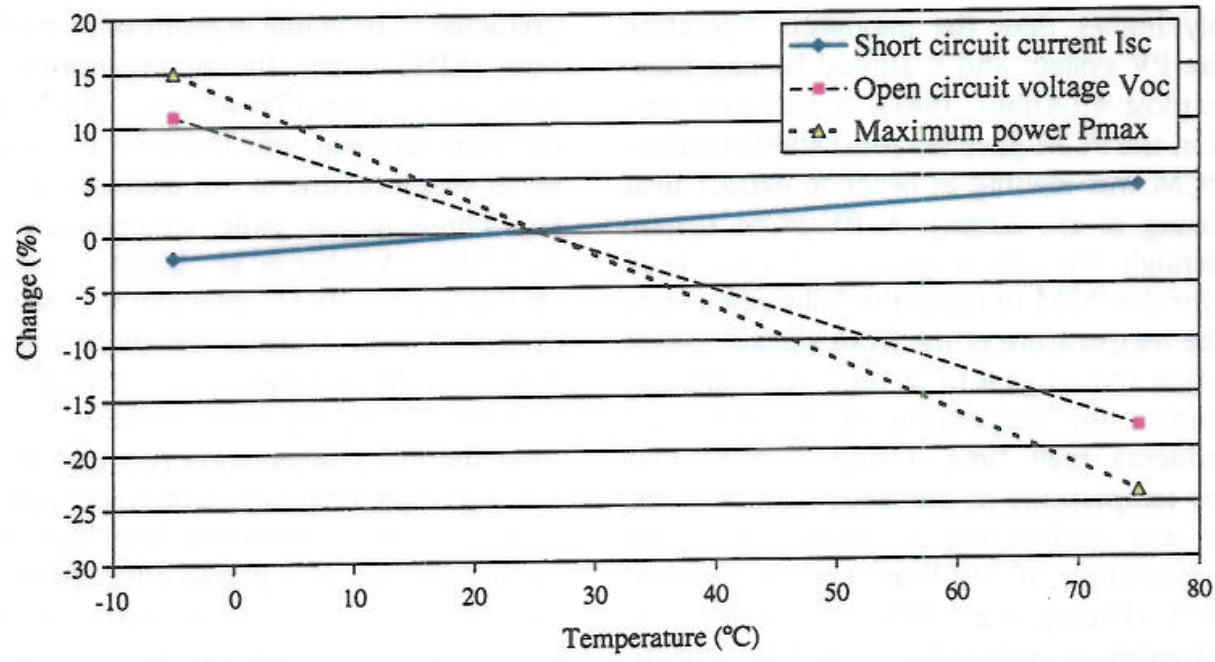

Fig. 19. The effect of temperature on cell operation (Markvart, 1994). 
(Salyer and Sircary, 1990, 1997). The absorption of large amounts of energy at a constant temperature is one of the main attractions of PCM for temperature control. Use of aluminium foam can increase effective PCM thermal conductivity with the choice of suitable foam being a function of the heat load, PCM module geometry and thermal boundary conditions ( $\mathrm{Pal}$ and Joshi, 1997, 1999). Currently available solid-liquid PCMs can be conveniently classified into three major categories (Jotshi et al., 1991, 1992; Antohe et al., 1996): inorganic compounds (Kimura and Kai, 1988), organic compounds, and eutectics of inorganic and/or organic compounds (Feldman et al., 1989). For the BIPV thermal control, organic-based PCMs in particular those which are paraffin-based, have the advantages of high heats of fusion, negligible supercooling, and low vapour pressure in the melt, are inert chemically, stable and self nucleating, have no phase segregation, are nontoxic and noncorrosive, inexpensive and widely available (Leoni and Amon 1997). Significant disadvantages of paraffin wax are low thermal conductivity (about one-half that of salt hydrates), large volume change during melting and freezing (approximately $10 \%$ by volume expansion or contraction) leading to leakage in the liquid phase, high wetting ability and flammability. Elastic containers and different container geometries may be used to overcome the volume change on melting and freezing.

A system using a phase change material (PCM) to moderate the BIPV temperature rise (PV/PCM) has been designed, fabricated, tested and simulated (Huang et al., 2004). Small scale practical experimental tests were carried out both in the laboratory and outdoors (Huang et al., 2006a; Hasan et al., 2007a,b). Three different PV/PCM systems were subsequently modelled, to determine the effect on BIPV temperature evolution of form of cooling fins for two different types of phase change materials. While the conventional aluminium fined PV panel with natural ventilation can reduce the temperature rise of the $\mathrm{PV}$, the use of a PV/PCM system can reduce the temperature rise of the PV much further. The PCM should have a flash point considerably higher than the maximum operating temperature of the PV system and it should be non-flammable and non-explosive (Abhat, 1981). A soft-iron wire matrix embedded in the PCM gave the most stable temperature when the PCM was melting in order to extract heat from the PV (Huang et al., 2006a). A PV/PCM system incorporating a straight fin with a spacing of $4 \mathrm{~mm}$ took the shortest time for the PCM to reach the full molten state and maintained the temperature of the front surface lowest for fin spacing within the range 4 to $20 \mathrm{~mm}$. With increasing incident insolation, the temperature on the front surface increases reducing melt time. Using a PCM that melts at $25^{\circ} \mathrm{C}$, the temperature at the front surface of the PV/PCM system was maintained at below $29^{\circ} \mathrm{C}$ for 130 min with an insolation of $750 \mathrm{Wm}^{2}$ and an ambient temperature of $23^{\circ} \mathrm{C}$ (Huang et al., 2006a). In an outdoor characterisation experiment undertaken in the UK, a depth of $40 \mathrm{~mm}$ of a paraffin-waxed based PCM with a melt point of $25^{\circ} \mathrm{C}$ was shown to provide significant PV temperature control and thus increased electrical conversion efficiency. Granular PCM that melts at $40^{\circ} \mathrm{C}$ can be used to reduce the temperature rise of a BIPV panel, however, the thermal control is not as effective as when using solid-liquid $25^{\circ} \mathrm{C}$ melt PCM (Huang et al., 2006a).

A three-dimensional (3D) numerical model has been developed to simulate the use of a phase change material linked to a PV system to control the temperature rise of BIPV. The model was used to predict temperatures, velocity fields and vortex formation within the system (Huang et al., 2006b). The 3D model was compared successfully with a $2 \mathrm{D}$ finite-volume heat transfer model (Huang et al., 2004) and validated experimentally. Velocity and temperature fields inside a PV/PCM system could be predicted successfully for a range of system geometries. Altering the boundary conditions employed in the simulations of the PV/PCM systern allowed for different levels of insolation, ambient temperatures and convective and radiative heat transfer to the surrounding environment. For simple line-axis systems the $2 \mathrm{D}$ model simulated accurately the predictions made using the $3 \mathrm{D}$ model. The temperature distribution within the PCM obtained using five pin fins to improve the heat transfer into the PCM has also been reported (Huang et al., 2007). Temperature distributions predicted for different insolation and ambient temperatures at the photovoltaic surface show that the lower temperature achieved leads to significant improvement in the operational efficiency of photovoltaic facades.

\subsection{Water and air-heating BIPV}

Where BIPV heat removal uses water (or an aqueous propylene glycol solution) as the working fluid, the cost is much higher due to the required plumbing, more complex façade and building hydronic systems integration and greater weight. Careful system output optimisation of water-heating "PV/T" systems is thus required to justify the initial capital cost investment though they have been predicted to be viable in terms of embodied energy payback time (EPT) under Indian conditions with EPT ranging from 4 to 14 years (Tiwari et al., 2007). Whilst BIPV hydronic heat removal will improve PV efficiency, should the water stagnate (due to, for example, pump failure) the very high consequential panel temperatures adversely affect PV durability (Affolter et al., 2000). Furthermore the thermal efficiency of a PV/T collector is lower than an optimised (non-PV) solar thermal flat-plate collector (Sandnes and Rekstad, 2002; Almeida and Olivera, 2008) due usually to most PV having poor radiative surface properties for solar thermal conversation (i.e. low solar thermal absorption and high long-wave emittance) and lack of an aperture cover to inhibit convective heat loss. Rectifying the latter by the addition of a glazed cover reduces PV performance due to increase PV optical losses and raises PV temperature. Despite these design challenges in appropriate conditions they can be viable economically. For example in 
Portugal payback times of between four and six years have been estimated for domestic installations (Almeida and Olivera, 2008). There are now over 25 types of water-heating PV/T systems have been available (Fraisse and Souyri, 2003) and their development continues (Fraisse et al., 2007; Charalambous et al., 2006).

Flat-plate air-heating photovoltaic solar thermal collectors also seek to yield an optimal combination of both electrical and thermal conversion efficiencies. Both steadystate (Cox and Raghuraman, 1985; Garg et al., 1991; Bhargava et al., 1991) and transient (Aste et al., 2008) energy and exergy (Joshi and Tiwari, 2007) analyses of such collectors have been developed. System length, mass flow rate, duct depth and packing factor were analysed by Bhargava et al. (1991) to compute the optimum photovoltaic cell area necessary to generate electricity sufficient to power the system's fan. A composite Trombe-Michel wall illustrated in Fig. 20 was modelled for a PV panel integrated into building facade (Zrikem and Bilgen, 1987; Mootz and Bezian, 1996). Air is drawn in through the inlet section, heated by solar radiation in the convection channel and discharged through the outlet section. Additional heat is delivered to the adjoining room by conduction through the solar PV panel and the insulation. The best electrical PV panel performance during convective heat recovery periods occured at the maximum channel spacing (Mootz and Bezian, 1996). Variable channel spacing proved to be the most efficient solution for both convective heat recovery and non-recovery periods.

A BIPV façade can act as an unglazed thermosyphon photovoltaic-thermal air-heating collector to provide natural ventilation in summer (Wang et al., 2006), pre-heated air in winter and electrical output throughout the year (Humm and Toggweiler, 1993; Sick and Erge, 1996; Bazilian and Prasad, 2002; Posnansky et al., 1992; Posnansky and Eckmanns, 1995; Lloret et al., 1995; Bloem and Ossenbrink, 1995, 1996; Wouters et al., 1996; Bendel et al., 1995; Shaw et al., 1995). A duct arranged behind the PV module

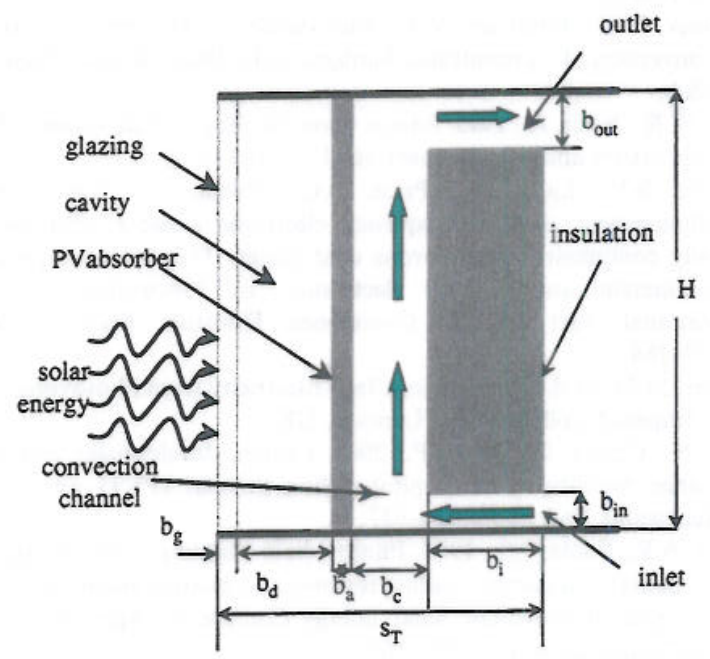

Fig. 20. Model for PV panel integrated into a building facade (Mootz and Berian, 1996). or mounting system, allows air flow induced by buoyancy from the back of the PV panel in a similar manner to a thermosyphoning air panel (Norton et al., 1992). The movement of the air in this duct is governed by a combination of natural convection (stack effects), and wind induced flow (Batagiannis and Gibbons, 2001). The temperature attained depends on the incident solar energy, surface area surrounding ambient air temperature, flow conditions, radiant surfaces, and cooling mechanisms and the flow and temperature distribution (Mosfegh et al., 1995; Yang et al., 1996; Sandberg and Mosfegh, 1996; Mosfegh and Sandberg, 1998; Brinkworth et al., 1997; Tonui and Tripanagnostopoulos, 2008). For air flow in a PV rear duct section, one wind direction may aid the air movement, and induce greater cooling of the modules, another wind direction may act against the required airflow direction, and reduce the cooling potential (Batagiannis and Gibbons, 2001). For a naturally-ventilated PV cladding element, buoyancy forces are balanced by the pressure drops due to the friction at the entrance and exit (Brinkworth et al., 2000). For zero wind velocity, flow through a PV ventilated stack is driven by buoyancy forces alone. In other cases the flow inside the duct becomes a mix of free and forced convection. In a long shallow duct flow is determined by internal flow resistance and the flow structure can be characterised by entrance lengths and the transition to turbulence. For a single vertical loop it was reported that the mass flow rate increased by $1.9 \mathrm{~ms}^{-1}$ when the heat input to the duct increased from 50 to $300 \mathrm{~W}$ (Brinkworth, 2000). Buoyancy induced airflow in a duct between the BIPV and the wall, even with a low mean airflow velocity of $0.1 \mathrm{~ms}^{-1}$, has been shown to reduce BIPV operating temperature by between $15-20^{\circ} \mathrm{C}$ giving a $15 \%$ increase in electrical conversion efficiency (Brinkworth et al., 1997).

Heat transfer within the cavity of a single concentrator, multiple concentrators, the space between adjacent concentrators and in an air duct behind the photovoltaics has been analysed for the low concentrating photovoltaic applications. Heat transfer in an asymmetric compound parabolic photovoltaic concentrator suitable for building façade integration has been investigated (Mallick et al., 2007). Free and forced convection at the rear of a PV concentrator provided a significant $\mathrm{PV}$ temperature reduction. A maximum possible solar cell temperature of $95^{\circ} \mathrm{C}$ was predicted for an incident insolation of $1000 \mathrm{Wm}^{-2}$, this decreased solar cell efficiency by $25 \%$ compared to a PV panel operating at the STC (Mallick et al., 2007). An inlet air velocity of $1.0 \mathrm{~ms}^{-1}$ in a $20 \mathrm{~mm}$ wide channel between the aperture cover and the reflector, decreased the PV cell temperature by $25.4 \mathrm{~K}$. A further reduction of temperature was achieved by providing an air channel to the rear of the aluminium back plate. The predicted air velocity in the space formed between the reflector troughs was very small, due to the enclosed nature of the boundary and near uniform boundary temperatures. A maximum temperature reduction of $34.2 \mathrm{~K}$ was predicted for a front and rear air gap of $20 \mathrm{~mm}$ with an inlet air velocity of $1.0 \mathrm{~ms}^{-1}$ (Mallick et al., 2007). 
The individual frames of each BIPV module can intrude into the air flow path. In order to reduce internal pressure drops in the cavity, the rear of the BIPV needs to be smooth, and the cross-section of the duct large. However, a smooth surface minimises the area for heat transfer, and a large cross-section reduces the air velocity over the surface. Both laboratory measurements and modelling have suggested that a duct depth of $100 \mathrm{~mm}$ is a reasonable optimum for the required airflow rates and velocities (Batagiannis and Gibbons, 2001). Without either regularly replaced or cleaned filters, airborne dust accumulation on a duct surface can also reduce the rate of heat transfer from the BIPV (Goossens and Kerschaever, 1999; Bilgen, 2000), Extended fins have be introduced into the flow to increase surface area, however, these also increase rear duct pressure losses, and their weight adds to the structural load placed on the building (Batagiannis and Gibbons, 2001).

\section{Conclusion}

The cost of a BIPV system can be lowered by reducing PV module and component manufacturing costs, installation costs, operation and maintenance costs and improving PV and other component efficiencies. Considerable enhancement of BIPV system performance is, however, achievable without improvement in PV cell performance. Given that the latter has, and will, continue to improve, the prospects for a greater range of viable BIPV applications is promising. The drivers can sometimes seem perverse, for example, the recent temporary shortage of silicon feedstock has led to advanced production technologies, thin film modules and concentrator devices being introduced more rapidly to the market (Jäger-Waldau, 2006) and more competition between manufacturers of BIPV specific systems (rather than PV modules). Cost and efficiency remain barriers to the widespread use of BIPV. Government subsidies and tax reduction on different BIPV products have been necessary to stimulate market development (Maycock, 1997). Many countries have such enhanced market stimulation mechanisms that should aid the achievement of economies of scale. Incorporating PV materials into products such as roofing materials, windows and awnings provides the opportunity for cost reduction by replacing common building materials with PV materials at marginal costs. In the future we can envisage, for example, LSCs comprise QDs or dyes seeded in plastic or glasses building façadès with photovoltaic (PV) cells attached to the edges, converting the direct and diffuse solar radiation into electricity for use in the building. Operation and maintenance costs can be reduced by using better more reliable fault tolerance systems and equipment. There factors will render BIPV more viable economically in a greater range of locations.

\section{Acknowledgements}

Each author's research on photovoltaics is supported in a range of diverse projects by Sustainable Energy Ireland,
Science Foundation Ireland Grants SFI/07/RFP/ENE719 and SFI/08/RFP/ENE025, Enterprise Ireland, the Engineering and Physical Sciences Research Council (UK), Department of Trade and Industry (UK), various programmes of the Commission of the European Communities, the Royal Academy of Engineering and numerous companies. We would acknowledge insights provided by Dr. A.D. Chatten and Professor Keith Barnham, Imperial College London, England Dr. S.N.G. Lo of University of Bath, England, Dr. T.J. Hyde, Dr. M. Smyth and Dr. A. Zacharopoulos of University of Ulster, Dr. T. Bruton, NAREC, Blyth, England, Dr. John Doran, Ahmed Hasan and Dr. Manus Kennedy, Dublin Institute of Technology and Dr. Brenda Rowan, Herriot-Watt University, Edinburgh Scotland.

\section{References}

Abhat, A., 1981. Low temperature latent heat thermal storage. In: Beghi, G. (Ed.), Ispra Courses on Energy Systems and Technology. D. Reidel Publishing Company, Holland, pp. 33-91.

Adsten, M., 2002. Solar Thermal Collectors at High Latitudes: Design and Performance of Non-Tracking Concentrators. PhD Thesis, Uppsala University, Sweden.

Affolter, P, Ruoss, D., Tuggweiler, P., Haller, A., 2000. New generation of hybrid solar PV/T collectors. Final Report DIS56360/16868, June.

Akhmad, K., Belley, F., Kitamura, A., Yamamoto, F., Akita, S., 1994. Effect of installation conditions on the output characteristics of photovoltaic modules. In: Conference Record of the IEEE Photovoltaic Specialists Conference, December, Hawaii, pp. 730-733.

Akkermans, E., Montambaux, G., Pichard, J.-L., Zinn-Justin, J., 1995. Mesoscopic Quantum Physics. Elsevier Science, Oxford, UK.

Alivisatos, A.P., 1998. Electrical studies of semiconductor-nanocrystal colloids. MRS Bulletin 18, 23.

Almeida, L., Olivera, A.C., 2008. Study of a hybrid PV-thermal solar system to provide electricity and heat in Portugal. International Journal of Ambient Energy 29, 153-161.

Almonacid, G., 1995. Optirnal size of a PV generator on a grid connected building. In: 13th European Photovoltaic Solar Energy Conference, October, Nice, France, pp. 2187-2190.

Alonso, M.C., Arribas, L.M., Chenlo, F., Cruz, I., 1997. Shading effect on a roof integrated grid-connected PV plant. In: 14th European Photovoltaic Solar Energy Conference, July, Barcelona, Spain, pp. 1891-1893.

Andreev, V.M., Grilikhes, V.A., Rumyantsev, V.D., 1997. Photovoltaic Conversion of Concentrated Sunlight. John Wiley \& Sons, New York, USA.

Anis, W.R., Nour, A., 1995. Energy losses in photovoltaic systems. Energy Conversion and Management 36 (11), 1107-1108.

Antohe, B.V., Lage, J.L., Price, D.C., Weber, J.L., 1996. Thermal Management of high frequency electronic systems with mechanically compressed microporous cold plates, Thermal management of commercial and military electronics. In: Proceedings of ASME National Heat Transfer Conference, Houston, Texas, USA, pp. 179-186.

Archer, M.D., Hill, R., 2001. In: Clean Electricity from Photovoltaics, vol. 1. Imperial College Press, London, UK.

Aste, N., Chiesa, G., Verri, F., 2008. Design, development and performance monitoring of a photovoltaic-thermal (PVT) air collector. Renewable Energy 33, 914-927.

Bahaj, A.S., Foote, J.S., 1994. Photovoltaic cladding, a design approach for panels and curtain walling for new and existing buildings. In: 12th European Photovoltaic Solar Energy Conference, April, Amsterdam, The Netherlands, pp. 1097-1099.

Bahaj, A.S., Ballard, J.R., James, P.A.B., Mucci, P.E.R., 1998. A new approach to photovoltaic roof tiles. In: 2nd World Conference and 
Exhibition on Photovoltaic Solar Energy Conversion, July, Vienna, Austria, pp. 2690-2693.

Bahaj, A.S., Braid, R.M., James, P.A.B., 2001. An assessment of the building integrated photovoltaic façade and it's operational mismatch losses at Southampton University. In: Proceedings of Renewable Energy in Maritime Island Climates, September, Belfast, Northern Ireland, pp. 111-118.

Bakos, G.C., Tsagas, N.F., 2002. Technical feasibility and economic viability of a small-scale grid connected solar thermal installation for electrical-energy saving. Applied Energy 72, 621-630.

Bakos, G.C., Soursos, M., Tsagas, N.F., 2003. Technoeconomic assessment of a building-integrated PV system for electrical energy saving in residential sector. Energy and Buildings 35, 757-762.

Balouktsis, A., Tsanakas, D., Vachtsevanos, G., 1987. On the optimum tilt angle of a photovoltaic array. International Journal of Solar Energy 5, 153-169.

Baltus, C.W.A, Eikelboom, J.A., van Zolingen, R.J.C., 1997. Analytical monitoring of losses in PV systems. In: 14th European Photovoltaic Solar Energy Conference, July, Barcelona, Spain, pp. 1547-1550.

Banyai, L., Koch, S.W., 1993. In: Semiconductor Quantum Dots; Atomic, Molecular and Optical Physics, vol. 2. World Scientific, Singapore.

Bari, S., 2000. Optimum slope angle and orientation of solar collectors for different periods of possible utilization. Energy Conversion and Management 41, 855-860.

Barnham, K.W.J., Marques, J.L., Hassard, J., O'Brien, P., 2000. Quantum-dot concentrator and thermodynamic model for the global redshift. Applied Physics Letters 76 (9), 1197-1199.

Barnham, K.W.J.I., Ballard, A., Bessière, A.J., Chatten, J.P., Connolly, N.J., Ekins-Daukes, D.C., Johnson, M.C., Lynch, M., Mazzer, T.N.D., Tibbits, G., Hill, J.S., Roberts, M.A., Malik, 2006. Quantum well solar cells and quantum dot concentrators. Nanostructured Materials for Solar Energy Conversion 517, 537

Barra, L., Catalantti, S., Fontana, F., Lavorante, F., 1984. An analytical method to determine the optimal size of a photovoltaic plant. Solar Energy 33 (6), 509-514.

Bartoli, B., Cuomo, V., Fontana, F., Serio, C., Silvestrini, V., 1984. The design of photovoltaic plants: an optimization procedure. Applied Energy 18, 37-47.

Batagiannis, P., Gibbons, C., 2001. Thermal assessment of silicon-based composite materials used in photovoltaics. In: Conference proceedings of Renewable Energy in Maritime Island Climates, Belfast, UK, pp. $151-157$.

Batchelder, J., Zewail, A., 1979. Luminescent solar concentrators: theory of operation and techniques for performance evaluation. Applied Optics 18, 3090-3110.

Bates, J.R., Standeven, M.A., Pearsall, N.M., Jones, D.L., 1998. Evaluation and validation of simulation packages for use in the design of building integrated photovoltaic systems. In: 2nd World Conference and Exhibition on Photovoltaic Solar Energy Conversion, July, Vienna, Austria, pp. 2736-2739.

Bazilian, M.D., Prasad, D., 2002. Modelling of a photovoltaic heat recovery system and its role in a design decision support tool for building professionals. Renewable Energy 27, 57-68.

Becker, H., Kiefer, K., Hoffman, V.U., Rindelhardt, U., Heilscher, G., 1997. Five years of operational experience in the German 1000-roofsPV programme results of monitoring and system inspection. In: 14th European Photovoltaic Solar Energy Conference, July, Barcelona, Spain, pp. 1677-1680.

Bendel, C., Gummich, D., Rudolf, U., 1995. Development of photovoltaic façade elements: technical aspects of multifunctional PV-facades. In: 13 th European Photovoltaic Solar Energy Conference, vol. 2. October, Nice, France, pp. 2168-2170.

Benemann, J., 1994. Multifunctional solar facades - a new challenge for photovoltaic. In: Conference Record of the IEEE Photovoltaic Specialists Conference, vol. 1. December. Waikoloa, HI, USA, pp. 784-787.

Benghanem, M., Maafi, A., 2000. A simplified method for estimating the performance of photovoltaic systems. In: World Renewable Energy Congress VI, July, Brighton, UK, pp. 1902-1905.
Bhargava, A.K., Garg, H.P., Agarwal, R.K., 1991. Study of a hybrid solar system-solar air heater combined with solar cell. Energy Conversion and Management 31 (5), 471-479.

Bhuiyan, M.M.H., Asgar, M.A., Mazumder, R.K., Hussain, M., 2000. Economic evaluation of a stand-alone residential photovoltaic power system in Bangladesh. Renewable Energy 21, 403-410.

Bilgen, E., 2000. Passive solar massive wall systems with fins attached on the heated wall and without glazing. ASME Journal of Solar Energy Engineering 122, 30-34.

Bishop, J.W., 1988. Computer simulation of the effects of electrical mismatches in photovoltaic cell interconnection circuits. Solar Cells 25 , 73-89.

Blaesser, G., 1997. PV system measurements and monitoring the European experience. Solar Energy materials and Solar Cells 47, 167-176.

Blaesser, G., Riesch, G., Munro, D.K., Kaut, W., Gillett, W.B., 1994. Operating experience with PV system from the THERMIE programme. In: 12th European Photovoltaic Solar Energy Conference, April, Amsterdam, The Netherlands, pp. 1159-1162.

Blanco, M.E., Gomez-Leal, E., Gordon, J.M., 1986. Asymmetric CPC solar collectors with tubular receiver: geometric characteristics and optimal configurations. Solar Energy 37 (1), 49-54.

Blanton, S.A., Hines, M.A., Guyot-Sionnest, P., 1996. Photoluminescence wandering in single CdSe nanocrystals. Applied Physics Letters 69 (25), 3905-3907.

Blewett, T., Horne, M., Hill, R., 1997. Heliodon prediction of shading on building integrated photovoltaic systems. In: Conference Record of the IEEE Photovoltaic Specialists Conference, September 30-October 3. Anaheim, CA, pp. 1393-1396.

Bloem, J.J., Ossenbrink, H.A., 1995. Thermal aspects of PV integration buildings. In: 13th European Photovoltaic Solar Energy Conference, Nice, France, pp. 2195-2198.

Bloem, J.J., Ossenbrink, H.A., 1996. Integration of photovoltaic hybrid technology in the JRC-ELSE building. In: Proceedings of 4 th European Conference on Solar Energy in Architecture and Urban Planning, March, pp. 571-574.

Böer, K.W., 1978. Payback of solar systems. Solar Energy 20, 225-232.

Boes, E.C., Luque, A., 1992. Photovoltaic concentrator technology. In: Renewable Energy, Sources for Fuel and Electricity, Washington, D.C., USA.

Bonvin, J., Roecker, C., Affolter, P., Muller, A., 1997. SOLBAC flat roof system and first installations. In: 14th European Photovoltaic Solar Energy Conference, July, Barcelona, Spain, pp. 1849-1850.

Bowden, S., Wenham, S.R., Coffey, P., Dickinson, M.R., Green, M.A., 1993). High efficiency photovoltaic roof tile with static concentrator. In: Conference Record of the IEEE Photovoltaic Specialists Conference, May, Louisvillem, pp. 1068-1072.

Bowden, S., Wenham, S.R., Dickinson, M.R., Green, M.A., 1994. High efficiency photovoltaic roof tiles with static concentrators. In: Conference Record of the IEEE Photovoltaic Specialists Conference, vol. 1. December, Waikoloa, HI, USA, pp. 774-777.

Brack, M., Wuillemin, D., Durisch, K., 1992. Experience and albedo measurements with a grid-connected PV plant in the Swiss Alps. In: 11 th European Photovoltaic Solar Energy Conference, October, Montreux, Switzerland, pp. 1327-1330.

Brinkworth, B.J., 2000. A procedure for the routine calculation of laminar free and mixed convection in inclined ducts. Heat and Fluid Flow 21, 456-462.

Brinkworth, B.J., Cross, B.M., Marshall, R.H., Hongxing, Y., 1997. Thermal regulation of photovoltaic cladding. Solar Energy 61 (3), 169178.

Brinkworth, B.J., Marshall, R.H., Ibarahim, Z., 2000. A validated model of naturally ventilated PV cladding. Solar Energy 69 (1), 67-81.

Brogren, M., Nostell, P., Karlsson, B., 2001. Optical efficiency of a PVthermal hybrid CPC module for high latitudes. Solar Energy 69, 173185.

Brogren, M., Wennerberg, J., Kapper, R., Karlsson, B., 2003. Design of concentrating elements with cis thin-film solar cells for façade integration. Solar Energy Materials and Solar Cells 75, 567-575. 
Bruendlinger, R., Bleterie, B., Milde, M., Oldenkamp, M., 2006. Maximum power point tracking performance under partially shaded PV array conditions. In: Proc 21st European Photovoltaic Cont, Barcelona, Spain.

Brunotte, M., Goetzberger, A., Blieske, U., 1996. Two-stage concentrator permitting concentration factors up to $300 \times$ with one-axis tracking. Solar Energy 56, 285-300.

Bruton, T.M., Sherborne, J., Heasman, K C., Ramsdale, C.M., 2002. Concepts for the manufacturing of silicon solar cell modules for use in concentrating systems up to $5 \times$. In: 29th IEEE Photovoltaic Specialists Conference, New Orleans, USA.

Bucciarelli, L.L., 1979. Power loss in photovoltaic arrays due to mismatch in cell characteristics. Solar Energy 23, 277-288.

Bücher, K., 1997. Site dependence of the energy collection of PV modules. Solar Energy Materials and Solar Cells 47, 85-94.

Bucher, K., Kleiss, G., Batzner, D., 1998. Photovoltaic modules in buildings: performance and safety. Renewable Energy 15, 545-551.

Budin, R., Budin, L., 1982. A mathematical model for shading calculations. Solar Energy 29 (4), 339-349.

Burgers, A., Slooff, A.L. Büchtemann, A., van Roosmalen, J.A.M., 2006. Performance of single layer luminescent concentrators with multiple dyes. In: Proceedings of the 4th World Conference on Photovoltaic Energy Conversion, May 2006, Hawaii.

Byrne, J., Letendre, S., Govindarajalu, C., Wang, Y., Nigro, R., 1996. Evaluating the economics of photovoltaics in a demand-side management. Energy Policy 24 (2), 177-185.

Caamaño, E., Lorenzo, E., 1996. Modelling and financial analysis tools for PV grid-connected systems. Progress in Photovoltaics: Research and Applications 4, 295-305.

Caamaño, E., Lorenzo, E., 1998. The Instituto de Energia solar PV grid connected building: three years of operation experience. In: 2 nd World Conference and Exhibition on Photovoltaic Solar Energy Conversion, July, Vienna, Austria, pp. 2710-2713.

Cendagorta, M., Friend, M.P., González, S., Sánchez, V., Dobón, F. 1998. Design and development of TEIDE inverter. In: 2nd World Conference and Exhibition on Photovoltaic Solar Energy Conversion, July, Vienna, Austria, pp. 2115-2117.

Chabot, B., 1998. From costs to price: economic analysis of photovoltaic energy and services. Progress in Photovoltaics: Research and Applications 6, 55-68.

Chambouleyron, I., 1996. Photovoltaics in the developing world. Energy 21 (5), 385-394.

Chapman, R.N., 1989. Development of sizing nomograms for stand-alone photovoltaic/storage systems. Solar Energy 43 (2), 71-76.

Charalambous, P.G., Maidment, G.G., Kalogirou, S.A., Yiakoumetti, K., 2006. Photovoltaic thermal (PY/T) collectors: a review. Applied Thermal Engineering 27 (2-3), 275-286.

Chatten, A.J., Barnham, K.W.J., Buxton, B.F., Ekins-Daukes, N.J., Malik, M.A., 2003. A new approach to modelling quantum dot concentrators. Solar Energy Materials and Solar Cells 75 (3-4), 363371.

Chatten, A.J., Farrell, D.J., Buxton, B.F., Büchtemann, A., Barnham, K.W.J., 2006. Thermodynamic modelling of luminescent solar concentrators and modules. In: Proceedings of the 21st European Photovoltaic Solar Energy Conference and Exhibition, September 2006, Dresden.

Chowdhury, B.H., Muknahallipatna, S., Cupal, J.J., Hamann, J.C., Shugar, D., 1997. A $50 \mathrm{~kW}$ distributed grid-connected photovoltaic generation system for the University of Wyoming. In: Conference Record of the IEEE Photovoltaic Specialists Conference, October, Anaheim, CA, USA, pp. 1369-1362.

Coppye, W., Maranda, W., Nir, Y., de Gheselle, L., Nijs, J., 1995. Detailed comparison of the inverter operation of two grid-connected PV demonstration systems in Belgium. In: 13th European Photovoltaic Solar Energy Conference, October, Nice, France, pp. 1881-1884.

Cox, C.H., Raghuraman, P., 1985. Design consideration for flat-plate photovoltaic thermal collectors. Journal of Solar Energy 35, 227 241.
Crick, F.J., McNelis, B., Wilshaw, A., Shaw, M., Parr, A., Laukamp, H., Overgaard, T., Pearsall, N., 1995. PV cladding prototypes for commercial building in Europe: development, construction and testing. In: 13th European Photovoltaic Solar Energy Conference, October, Nice, France, pp. 2171-2174.

Crick, F.J., Wilshaw, A., Pearsall, N., Hynes, K., Shaw, M., Young, G. Baker, P., 1998. PV cladding thermal gains: experimental results from three PV cladding systems investigating the effects of design on the operational temperatures. In: 2nd World Conference and Exhibition on Photovoltaic Solar Energy Conversion, Vienna, Austria, pp. 2062 2065.

Cross, B.M., Hongxing, Y., Morgan, T.R., 1994. Development, testing and first installations of an integrated solar roof system. In: Proceedings of the First World Conference on PV Energy Conversion, Hawaii, USA, pp. 1020-1023.

de Graaf, L.E., van der Weiden, T.C.J., 1994. Characteristics and performance of a PV-system consisting of 20 AC-module. In: Proceedings of the 24th IEEE Photovoltaic Specialists Conference, vol. 1. December, Waikoloa, HI, USA, pp. 921-924.

de Haan, S.W.H., Oldenkamp, H., Wildenbeest, E.J., 1994. Test results of a $130 \mathrm{~W}$ AC module, a modular solar ac power station. In: Proceedings of the 24th IEEE Photovoltaic Specialists Conference, vol. 1. December, Waikoloa, HI, USA, pp. 925-928.

Decker, B., Jahn, U., 1997. Performance of 170 grid connected PV plants in Northern Germany - analysis of yields and optimization potentials. Solar Energy 59 (4-6), 127-133.

Decker, B., Jahn, U., Rindelhardt, U., Vaaen, W., 1992. The German 1000-roof-photovoltaic-programme: system design and energy balance. In: 11th European Photovoltaic Solar Energy Conference, October, Montreux, Switzerland, pp. 1497-1500.

DeGheselle, L., 1997. Extended electrical and thermal monitoring of the first roof-integrated PV systems in flanders. In: 14th European Photovoltaic Solar Energy Conference, Barcelona, Spain.

Dinwoodie, T., Shugar, D., 1994. Optimizing roof-integrated photovoltaics: a case study of the PowerGuard ${ }^{\mathrm{Tx}}$ roofing title. In: Conference Record of the IEEE Photovoltaic Specialists Conference, vol. 1. December, Waikoloa, HI, USA, pp. 1004-1007.

Duffie, J.A., Beckman, W.A., 1991. Solar Engineering of Thermal Process. John Wiley \& Sons, Inc, New York, USA.

Dunlop, E.W., Bloem, H., Ossenbrink, H.A., 1997. Electrical characterisation and analysis of operating conditions of amorphous silicon building integrated photovoltaic modules. In: 14th European Photovoltaic Solar Energy Conference, July, Barcelona, Spain, pp. 2037 2041 .

Durand, S.J., Bowling, D.R., Risser, V.V., 1990. Lessons learned from testing utility connected PV systems. In: 21st IEEE Specialists Conference, May, Orlando, Florida, pp. 909-913.

Eames, P.C., Norton, B., 1993a. Validated united model for the optics and heat transfer in line-axis concentrating solar energy collectors. Solar Energy 50, 339-355.

Eames, P.C., Norton, B., 1993b. Detailed parametric analysis of heat transfer in CPC solar energy collectors. Solar Energy 50 (No. 4), 321338.

Eames, P.C., Norton, B., 1995. Thermal and optical consequences of the introduction of baffles into compound parabolic concentrating solar energy collector cavities. Solar Energy 55 (2), 139-150.

Eames, P.C., Norton, B., Tripagnostopoulos, Y., Yianoulis, P., 1999. Modelling line-axis solar concentrators in the medium temperature range. Renewable Energy 16, 743-748.

Eames, P.C., Zacharopoulos, A., McLarnon, D., Hyde, T.J., Norton, B., 2000. Development and experimental characterisation of low cost façade integrated concentrator photovoltaics. In: Proceedings of 20/ 20 Vision CIBSE/ASHRAE Conference, Dublin, Ireland (CDROM).

El-Hefnwai, S.H., Hanafi, A.A., 1998. Sizing and sensitivity analysis of remote area stand-alone PV system. In: Proceedings of the 1998 International Solar Energy Conference, June, Albuquerque, NM, USA, pp. 251-255. 
Endo, E., Kurokawa, K., 1994. Sizing procedure for photovoltaic systems In: Conference Record of the IEEE Photovoltaic Specialists Conference, vol. 1. December, Waikoloa, HI, USA, pp. 1196-1198.

Fahmy, H., 1998. Mathematical and numerical model for PV cell steady state temperature distribution. In: International Solar Energy Conference, June, Albuquerque, NM, USA, pp. 225-231.

Fanney, A.H., Dougherty, B.P., Davis, M.W., 2001. Measured performance of building integrated photovoltaic panels. ASME Journal of Solar Engineering 123, 187-192.

Farrell, D.J., Chatten, A.J., Büchtemann, A., Barnham, K.W.J., 2006. Fabrication, characterisation and modelling of quantum dot solar concentrator stacks. In: Proceedings of the 4th World Conference on Photovoltaic Energy Conversion, May 2006, Hawaii.

Feldman, D., Shapiro, D.B., Fuks, C.J., 1989. Fatty acids and their mixtures as phase change materials for thermal energy storage. Solar Energy Materials 18, 210-217.

Fraisse, G., Souyri, B., 2003. Rapport Programme Energie CNRS: compte rendu scientifique conception I'un capteur PV/T-eau; rapport premiére année PRI 6.2 Intégration de capteurs hybrids photovoltaiques thermiques au bait, no CNRS 752524/00 Juin.

Fraisse, G., Mérézo, C., Johannes, K., 2007. Energy performance of water hybrid PV/T collectors applied to combisystems of the Direct Solar Floor type. Solar Energy 81, 1426-1438.

Frei, J.A., Chen, Y.T., Boehm, R.F., 1997. Solar power output correction with utility demand in Southern Nevada. ASME Journal of Solar Energy Engineering 119, 141-146.

Friedman, P.S., 1981. Luminescent solar concentrators. Optical Engineering $20(6), 887-892$.

Fu, H., Zunger, A., 1996. InP quantum dots: electronic structure, surface effects and the redshifted emission. Physical Review B 56 (3), 14961508.

Fuentes, M., Roaf, S., 1997. Optimising the thermal and electrica performance of roof integrated photovoltaics: case study. In: Proceedings of 14th E.C. Photovoltaic Solar Energy Conference.

Gadsden, S., Rylatt, M., Lomas, K., 2003. Putting solar energy on the urban map: a new GIS-based approach for dwellings. Solar energy 74 , $397-407$.

Gajbert, H., Hall, M., Karlsson, B., 2007. Optimisation of reflector and module geometrics for stationery, low-concentrating, façade-integrated photovoltaic systems. Solar Energy Materials and Solar Cells 91, 1788-1799.

Gallagher, S.J., Eames, P.C., Norton, B., 2002. Quantum dot solar concentrators. In: Proceedings of World Renewable Energy Congress, 29th June-4th July, Cologne, Germany, p. 364.

Gallagher, S.J., Eames, P.C., Norton, B., 2004a. Predicting the behaviour of quantum dot solar concentrators using a ray trace approach International Journal of Ambient Energy 25 (1), 47-56.

Gallagher, S.J., Norton, B., Eames, P.C., (2004b). Characterisation of quantum dot solar performance using a continuous solar simulator. In: Proceedings of the 19th European Photovoltaic Solar Energy Conference and Exhibition, June, Paris, France (CD-ROM).

Gallagher, S.J., Norton, B., Eames, P.C., 2007a. Quantum dot solar concentrator: electrical conversion efficiencies and comparative concentrating factors of fabricated devices. Solar Energy 81 (6), 813-821.

Gallagher, S.J., Rowan, B.C., Doran, J.D., Norton, B., 2007b. Quantum dot solar concentrator: device characterisation using spectroscopic techniques. Solar Energy 81 (4), 540-547.

Garg, H.P., Agarwal, P.K., Bhargava, A.K., 1991. The effect of plane booster reflectors on the performance of a solar air heater with solar cells suitable for a solar dryer. Energy Conversion and Management $32,543-554$.

Gerion, D., Pinaud, F., Willaims, S.C., Parak, W.J., Zanchet, D., Weiss, S., Alivisatos, A.P., 2001. Synthesis and properties of biocompatible water-soluble silica-coated $\mathrm{CdSe} / \mathrm{ZnS}$ semiconductor quantum dots. Journal of Physical Chemistry B 105, 8861-8871.

Ghiraldi, A., 1988. Passive conditioning systems for temperature control in telecommunications equipment enclosure. In: 10th Internationa
Telecommunication Energy Conference (INTELEC), San Diego, CA, USA.

Goetzberger, A., 1978. Fluorescent solar energy collectors: operating conditions with diffuse light. Applied Physics 16, 399-404.

Goetzberger, A., Greubel, W., 1977. Solar energy conversion with fluorescent concentrators. Applied Physics 14, 123-139.

Goetzberger, A., Wittwer, V., 1979. Fluorescent planar collector-concentrators for solar energy conversion. Advanced Solid State Physics 19. 427-451.

Goetzberger, A., Stahl, W., Wittwer, V., 1985. Physical limitations of the concentration of direct and diffuse radiation. In: Proceedings of the 6 th European Photovoltaic Solar Energy Conference, pp. 209-215.

Goldschmidt, J.C., Glunz, S.W., Gombert, A., Willeke, G.P., 2006. Advanced fluorescent concentrators. In: Proceedings of the $21 \mathrm{st}$ European Photovoltaic Solar Energy Conference and Exhibition, September, Dresden, Germany (CD-ROM).

Goldstein, L.H., Case, G.R., 1978. PVSS - a photovoltaic system simulation program. Solar Energy 21, 37-43.

Gonzalez, C., 1986. Photovoltaic array loss mechanisms. Solar Cell 18, 373-382.

Goossens, D., Kerschaever, E.V., 1999. Aeolian dust deposition on photovoltaic solar cells: the effects of wind velocity and airborne dust concentration on cell performance. Solar Energy 66, 277-289.

Gordon, J.M., 1987. Optimal sizing of stand-alone photovoltaic solar power systems. Solar Cells 20, 295-313.

Goswami, D.Y., Kreith, F., Kreider, J., 1999. Principles of Solar Engineering, second ed. George H. Buchanan Co., Philadelphia, PA.

Gow, J.A., Manning, C.D., 1999. Development of a photovoltaic array model for use in power-electronics simulation studies. IEE Proceedings: Electric Power Applications 146 (2), 193-200.

Grande, M., Moss, G., Milward, S., Saich, M., 1983. The application of thin film wavelength-shifting coatings of Perspex to solar energy collection. Journal of Physics D: Applied Physics 16, 2525-2535.

Green, M.A., 1995. Silicon Solar Cells: Advanced Principles and Practice. Bridge Printery, Sydney, Australia.

Green, M.A., 2003. Crystalline and thin-film silicon solar cells: state of the art and future potential. Solar Energy 74, 181-192.

Green, M.A., 2007. Thin-film solar cells: review of material technologies and commercial status. Journal of Materials Science. Materials in Electronics 18, 15-19.

Groehn, H.G., Brathels, H., 1994. PV-modules at the façade of an inner coutyard- measurements and simulation. In: Proceedings of IEEE First World Conference on Photovoltaic Energy Conversion, New York, USA, pp. 1016-1019.

Gross, M.A., Martin, S.O., Pearsall, N.M., 1997. Estimation of output enhancement of a partially shaded BIPV array by the use of AC modules. In: 26th Photovoltaic Specialists Conference, October, Anaheim, CA, pp. 1381-1385.

Groumpos, P.P., Papageorgiou, G., 1987. An optimal sizing method for stand-alone photovoltaic power systems. Solar Energy 38 (5), 341-351.

Haas, R., 1994. The value of photovoltaic electricity for utilities. Solar Energy Materials and Solar Cells 35, 421-427.

Haas, R., Ornetzeder, M., Hametner, K., Wroblewski, A., Hübner, M., 1999. Socio-economic aspects of the Austrian $200 \mathrm{~kW}_{\mathrm{p}}$-photovoltaicrooftop programme. Solar Energy 66 (3), 183-191.

Haeberlin, H., Liebi, C., Beutler, C., 1997. Inverters for grid connected PV systems: test results of some new inverters and latest reliability data of the most popular inverters in Switzerland. In: 14th European Photovoltaic Solar Energy Conference, July, Barcelona, Spain, pp. 2184 2187.

Hagemann, I., 1996. PV in buildings-the influence of PV on the design and planning process of a building. Renewable Energy 8 (1-4), 467470.

Hasan, A., McCormack, S.J., Huang, M.J., Norton, B., 2007a. Experimental design for integrating phase change materials into building integrated photovoltaics for thermal control. In: Proceedings of the 3rd Photovoltaic Science, Applications and Technology Conference (PVSAT-3), March, Durham, UK, pp. 105-108. 
Hasan, A., Schnitzler, E., McCormack, S. J., Huang, M. J., Norton, B., $2007 \mathrm{~b}$. Phase change materials for thermal control of building integrated photovoltaics: experimental design and findings. In: Proceedings of the 22nd European Photovoltaic Solar Energy Conference and Exhibition, September, Milan, Italy (CD-ROM).

Hashimoto, O., Shimizu, T., Kimura, G., 2000. A novel high performance utility interactive photovoltaic inverter system. In: 35th IAS Annual Meeting and World Conference on Industrial Applications of Electrical Energy, October, Rome, Italy, pp. 2255-2260.

Hass, R., 1997. Successful dissemination programs for residential PV applications - an international survey. In: Conference Record of the IEEE Photovoltaic Specialists Conference, October, Anaheim, CA, USA, pp. 1231-1236.

Hermann, A.M., 1982. Luminescent solar concentrators - a review. Solar Energy 29 (4), 323-329.

Hernández, J.C., Vidal, P.G., Almonacid, G., 1998. Photovoltaic in gridconnected building sizing and economic analysis. Renewable Energy $15,562-565$.

Hill, R., Pearsall, N.M., Pudie, N., Nobel, R., Scott, R.D.W., McNelis, B., 1994. Architecturally integrated PV façade for commercial building in north east England. In: 12th European Photovoltaic Solar Energy Conference, April, pp. 695-698.

Hiraoka, S., Fujii, T., Takakura, H., Hamakawa, Y., 2003. Tilt angle dependence of output power in an $80 \mathrm{~kW}_{\mathrm{p}}$ hybrid PV system installed at Shiga in Japan. Solar Energy Materials and Solar Cells 75, 781-786.

Hirata, Y., Tani, T., 1994. Evaluation of photovoltaic modules considering spectral solar radiation. Electrical Engineering in Japan 114 (8), 93-105.

Hoffman, A.R., Maag, C.R., 1980. Airborne particulate soiling of terrestrial photovoltaic modules and cover materials.In: Proceeding, Annual Technical Meeting-Institute of Environmental Sciences, May, Philadelphia, PA, USA, pp. 229-236.

Horigichi, M., Tanda, M., Watanuki, Y., Yoshida, T., 1996. A flexible PV module for residential applications. In: 9 th International Photovoltaic Science and Engineering Conference, November, Japan, pp. 183-184.

Hsiao, Y., Chen, C., 2002. Maximum power tracking for photovoltaic power system. Conference Record - IAS Annual Meeting (IEEE Industry Applications Society) 2, 1035-1040.

Huang, M.J., Eames, P.C., Norton, B., 2004. Thermal regulation of building-integrated photovoltaics using phase change materials. International Journal of Heat and Mass Transfer 47, 2715-2733.

Huang, M.J., Eames, P.C., Norton, B., 2006a. Experimental performance of phase change materials for limiting temperature rise building integrated photovoltaics. Solar Energy 80, 1121-1130.

Huang, M.J., Eames, P.C., Norton, B., 2006b. Comparison of a small scale 3-D PCM thermal storage model with a validated 2-D thermal model. Journal of Solar Energy Materials and Solar Cells 90, 19611972.

Huang, M.J., Eames, P.C., Norton, B., 2007. Comparison of predictions made using a new $3 \mathrm{D}$ phase change material thermal control model with experimental measurements and predictions made using a validated $2 \mathrm{D}$ model. International Joumal of Heat Transfer Engineering 28 (1), 31-37.

Humm, O., Toggweiler, P., 1993. Photovoltaic und Architecture, Photovoltaics in Architecture. Birkhäuser Verlag, Basel, Switzerland.

Hussein, K.H., Muta, I., Hoshino, T., Osakada, M., 1995. Maximum photovoltaic power tracking: an algorithm for rapidly changing atmospheric conditions. IEE Proceeding: Generation, Transmission and Distribution 142 (1), 59-64.

Iliceto, A., Vigotti, R., 1998. The largest PV installation in Europe: perspective of multimegawatt PV. Renewable Energy 15, 48-53.

Iliceto, A., Belli, G., Lambri, L., Toninelli, F., 1997. ENEL's 3MWp plant at Serre: plant performance analysis. In: 14th European Photovoltaic Solar Energy Conference, July, Barcelona, Spain, pp. 2670-2674.

Imamura, M.S., 1993. Recent trends and advances in photovoltaic system technology in Europe. International Journal of Solar Energy 14, 1-17.
Imamura, M.S., 1994. Grid-connected PV plants: field experiences in Germany and a pursuit of higher solar energy collection efficiency. Solar Energy Materials and Solar Cells 35, 359-374.

Imamura, M.S., Helm, P., Palz, W., 1992. Photovoltaic system technology a European Handbook. H.S. Stephens and Associates, Bedford, England.

Ingersoll, J.G., 1986. Simplified calculation of solar cell temperatures in terrestrial photovoltaic arrays. ASME Journal of Solar Energy Engineering 108, 95-101.

Ishikawa, Y., Ihara, T., Toshio, H., Watanuki, Y., Kato, S., Ota, H., Sakai, H., 1994a. A new flexible a-Si PV module and its application to rooftop PV systems. In: Conference Record of the IEEE Photovoltaic Specialists Conference, vol. 1. December, Waikoloa, HI, USA, pp. 986-989.

Itoh, M., Takahashi, H., Fujii, T., Takakura, H., Hamakawa, Y., Matsumoto, Y., 2001. Evaluation of electric energy performance by democratic module PV system field test. Solar Energy Materials and Solar Cells 67, 435-440.

Izquierdo, S., Rodrigues, M., Fueyo, N., 2008. A method for estimating the geographical distribution of the available roof surface area for large scale photovoltaic energy-potential evaluations. Solar Energy 82, 929-939.

Izu, M., Ovshinsky, H.C., Whelnan, K., Fatalski, L., Ovshinsky, S.R., Glatefelter, T., Younman, K., Hoffman, K., Banerjee, K., Yang, J., Guha, S., 1994. Lightweight flexible rooftop PV module. In: Conference Record of the IEEE Photovoltaic Specialists Conference, vol. 1. December, Waikoloa, HI, USA, pp. 990-993.

Jäger-Waldau, A., 2006. PV Status Report 2006: Research, solar cell production and market implementation of photovoltaics. Report 22346. European Commission Joint Research Centre, Ispra, Italy.

Jahn, U., Grochowski, D., Tegtmeyer, D., Rindelhardt, U., Teichmann, G., 1994. Detailed monitoring results and operating experience from 250 grid connected photovoltaic systems in Germany. In: 12th European Photovoltaic Solar Energy Conference, April, Amsterdam, The Netherlands, pp. 919-922.

Jahn, U., Niemann, M., Blaesser, G., Dahl, R., Castello, S., Clavadetscher, L., Faiman, D., Mayer, D., van Otterdijk, K., Sachau, J., Sakuta, K., Yamaguchi, M., Zoglauer, M., 1998. International energy agency TASK II database on photovoltaic power systems: statistical and analytical evaluation of PV operational data. In: 2nd World Conference on Photovoltaic Solar Energy Conversion, July, Vienna, Austria, pp. 2802-2805.

James, P.A.B., Jentch, M.F., Bahaj, A.S., 2009. Quantifying the added value of BIPV as a shading solution in atria. Solar Energy 83, 202-231.

Jantsch, M., Schmidt, H., Schmid, J., 1992. Results of the concerted action on power conditioning and control. In: 11th Photovoltaic Solar Energy Conference, October, Montreux, Switzerland, pp. 1589-1593.

Ji, J., Pei, G., Chow, T.-T., Liu, K., He, H., Lu, J., Hen, C., 2008. Experimental study of photovoltaic solar assisted heat pump system. Solar Energy 82, 45-52.

Joshi, A.S., Tiwari, G.M., 2007. Monthly energy and exergy analysis of hybrid photovoltaic (PV/T) system for the Indian climate. International Journal of Ambient Energy 28, 99-122.

Jotshi, C.K., Goswami, D.Y., Tomlinson, J.J., 1991. Thermal energy storage in phase change materials for temperature application 0 to $200^{\circ} \mathrm{C}$. Report No. SEEC 91-1, August, Solar Energy and Energy Conversion Lab., University of Florida, Gainesville, Fl, USA.

Jotshi, C.K., Tomlinson, J.J., Tomlinson, J.J., 1992. Solar thermal energy storage in phase change materials. In: Proceedings of 1992 Annual conference American Solar Energy Society, USA.

Jung, B.J., Yoon, C.B., Shim, H.K., Do, L.M., 2001. Pure-red dye for organic electroluminescent devices: bis-condensed DCM derivatives. Advanced Functional Materials 11 (6), 430-434.

Kabakov, V.I., Levin, L.B., 1994. A choice of the position of receiver with photocells in parabolic trough concentrator. Solar Energy Materials and Solar Cells 33, 45-49.

Kato, K., Nobue, Y., Yokoda, T., Hayashi, F., 2002. Progress in PV technology development under the new sunshine program JFY 1997. 
2000-PV system technology. In: 29th Photovoltaic Specialists Conference, New Orleans, Louisiana, pp. 1718-1721.

Kaye, R.J., 1994. A new approach to optimal sizing of components in stand-alone photovoltaic power systems. In: 24th IEEE Photovoltaic Specialists Conference, December, Hawaii, USA, pp. 1192-1195.

Kaye, R.J., O'Brien, R., Ghiotto, N., McKee, P., 1997. Site selection and assessment of rooftop photovoltaic installations. In: 14th European Photovoltaic Solar Energy Conference, July, Barcelona, Spain, pp. 1979-1982.

Kazmerski, L.L., 2006. Solar photovoltaics R \& D at the tipping print: a 2005 technology overview. Journal of Election Speetroseday and Rehertrel Phenomena 150, 105-135.

Keller, L., Affolter, P., 1992. Optimizing the panel area of a photovoltaic system, in relation to the static inverter. In:11th E.C. Photovoltaic Solar Energy Conference, October, Montreux, Switzerland, pp. 11591162.

Keller, L., Affolter, P., 1995. Optimizing the panel area of a photovoltaic system in relation to this static inverter-practical results. Solar Energy $55(1), 1-7$.

Kennedy, M., McCormack, S.J., Doran, J.D., Norton, B., 2007. Modelling of re-absorption losses in quantum dot solar concentrators. In: Proceedings of the 3rd Photovoltaic Science, Applications and Technology Conference (PVSAT-3), March 28th-30th, Durham, UK, pp. 123-126.

Kennedy, M., McCormack, S.J., Doran, J.D., Norton, B., 2009. Improving the optical efficiency and concentration of a single plate quantum dot solar concentrator using NIR emitting quantum dots. Solar Energy 83, 978-981.

Keoleian, G.A., Lewis, G.M.D., 1997. Application of life-cycle energy analysis to photovoltaic module design. Progress in Photovoltaics Research and Applications 5, 287-300.

Kern, J., Harris, I., 1975. On the optimum tilt of a solar collector. Solar Energy 17, 97-102.

Khouzam, K., 1997. Prospect of domestic grid connected PV systems under existing tariff conditions. In: 26th Photovoltaic Specialists Conference, October, Anaheim, CA, USA, pp. 389-1392.

Kiefer, K., Körkel, Th., Reinders, A., Rössler, E., Wiemken, E., 1995. 2250 PV-roof in Germany-operating results from intensified monitoring and analysis through numerical modelling. In: 13th European Photovoltaic Solar Energy Conference, October, Nice, France, pp. 575-579.

Kienzlen, V., Gordon, J.M., Kreider, J.F., 1988. The reverse flat plate collectors: a stationary, non-evacuated, low-technology, medium temperature solar collector. Journal of Solar Energy Engineering $110,23-30$.

Kil, A.J., van der Weiden, T.C.J., 1994. Performance of modular grid connected PV systems with undersized inverters in Portugal and the Netherlands. In: Conference record of the IEEE Photovoltaic Specialists Conference, December, Waikoloa, HI, USA, pp. 10281031.

Kimura, H., Kai, J., 1988. Mixtures of calcium chloride hexahydrate with some salt hydrates or anhydrous salts as latent heat storage materials. Energy Conversion and Management 28, 197-200.

Kjar, S.B., Pederson, J.K., Blaabjerg, F., 2005. A review of simple-phase grid-connected inventors for photovoltaic modules. IEE Transection on Industrial Application 41, 1292-1306.

Klein, et al., 2000. TRNSYS 15, A Transient Simulation Program, Solar Energy Laboratory, University of Wisconson, Madison, Wisconsin, WI.

Kleinkauf, W., Sachau, J., Hempel, H., 1992. Developments in inverters for photovoltaic systems. In: 11th E.C. Photovoltaic Solar Energy Conference, October, Montreux, Switzerland, pp. 1029-1033.

Kondepudi, R., Srinivasan, S., 1990. Optical Studies on some dyes for liquid solar concentrators. Solar Energy Materials 20, 257-263.

Koner, P.K., Dutta, V., Chopra, K.L., 2000. A comparative life cycle energy cost analysis of photovoltaic and fuel generator for load shedding application. Solar Energy Materials and Solar Cells 60, 309322.
Korech, O., Gordon, J.M., Katz, E.A., And, Feuermann.D., Eisenberg, N., 2007. Dielectric rnicroconcentrators for efficiency enhancement in concentrator solar cells. Optics Letters 32, 2789-2791.

Krauter, S., Hanitsch, R., Campbell, P., Wenham, S.R., 1994. In: Proceedings 12th European Photovoltaic Solar Energy Conference, Amsterdam, Netherlands, pp. 1194-1197.

Kremer, P., Diwes, A., 1998. Grid friendly PV-IGBT power condition units from $20 \mathrm{KVA}$ up to $1.2 \mathrm{MVA}$. In: 2nd World Conference and Exhibition on Photovoltaic Solar Energy Conversion, July, Vienna, Austria, pp. 2024-2027.

Krenzinger, A., Wagner, J.A., 1992. Computer simulation of stand alone PV systems for developing countries. In: 11th European Photovoltaic Solar Energy Conference, October, Montreux, Switzerland, pp. 1411-1414.

Kuo, Y.C., Liang, T.J., Chen, J.F., 2001. Novel maximum-power-pointtracking controller for photovoltaic energy conversion system. IEEE Transactions on Industrial Electronics 48 (3), 594-601.

Kurokawa, K., Sugiyama, H., Sakamoto, K., Ohshiro, T., Sakuta, K., Matsuo, T., Katagiri, T., 1997a. System monitoring database and performance analysis in Japanese field test program. In: 14th European Photovoltaic Solar Energy Conference, July, Barcelona, Spain, pp. 2046-2049.

Kurokawa, K., Sugiyama, H., Uchida, D., Sakuta, K., Sakamoto, K., Ohshiro, T., Matsuo, T, Katagiri, T., 1997b. Extended performance analysis of $70 \mathrm{PV}$ systems in Japanese field test program. In: Conference Record of the IEEE Photovoltaic Specialists Conference, October, Anaheim, CA, USA, pp. 1249-1252.

Lanzerstorfer, S., Bauer, G, Wilk, H., 1995. Losses by reflection of crystalline PV modules. In: 13th European Photovoltaic Solar Energy Conference, October, Nice, France, pp. 2294-2297.

Lasnier, F., Ang, T.G., 1990. Photovoltaic Engineering Handbook. Adam Hilger, Bristol, England.

Lasnier, F., Juen, W.Y., 1990. The sizing of stand-alone photovoltaic systems using the simulation technique. RERIC International Energy Journal 12 (1), 21-39.

Laukamp, H., Leithold, W., Rehg, U., 1994. 'Solarzentrum Freiburg' Europes's first photovoltaic structural glazing façade. In: 12th European Photovoltaic Solar Energy Conference, April, pp. 928-931.

Laukamp, H., Jantsch, M., Brunner, M., Schmidt, H., Leithold, W., Rehg, U., 1995. Solarzentrum freiburg - operational results from a structural glazing façade. In: 13th European Photovoltaic Solar Energy Conference, Nice, France.

Lazou, A.A., Anastassios, D.P., 2000. The economics of photovoltaic stand-alone residential households: a case study for various European and Mediterranean locations. Solar Energy Materials and Solar Cells $62,411-427$.

Leoni, N., Amon, C.H., 1997. Transient thermal design of wearable computers with embedded electronics using phase change materials, HTD-343. In: National Heat Transfer Conference, vol. 5. ASME 1997, USA, pp. 49-56.

Leutz, R., Suzuki, A., Akisawa, A., Kashiwagi, T., 1999a. Nonimaging Fresnel lens concentrator - the prototype. In: Proceedings of the First International Power and Energy Conference (INT-PEC), December, Gippsland, Australia.

Leutz, R., Suzuki, A., Akisawa, A., Kashiwagi, T., 1999b. Nonimaging Fresnel lens concentrators for photovoltaic applications. In: Proceedings ISES Solar World Congress, July, Jerusalem, Israel.

Leutz, R., Suzuki, A., Akisawa, A., Kashiwagi, T., 1999c. Design of a nonimaging Fresnel lens for solar concentrators. Solar Energy 65 (6), 379-388.

Leutz R., Suzuki A., Akisawa A., Kashiwagi T., 2000. Flux densities in optimum nonimaging Fresnel lens solar concentrators for space. In: Proceedings of the 28th IEEE Photovoltaic Specialists Conference, September, Anchorage, Alaska, USA.

Lin, G.H., Carlson, D.E., 2000. Photovoltaics in the year 2025. International Journal of Hydrogen Energy 25, 807-811.

Lloret, A., Andreu, J., Merten, J., Aceves, O., Sabata, L., Sen, F., Puigollers, J., Person, C., Chantant, M., Servant, J.M, Eicker, U., 1995. The Mataró Public Library: a $53 \mathrm{~kW}_{\mathrm{p}}$ grid connected building 
with integrated PV-thermal multifunctional modules. In: 13th European Photovoltaic Solar Energy Conference, vol. 1. October, Nice, France, pp. 23-27, 490-493.

Lloret, A., Andreu, J., Merten, J., Puigdollers, J., Aceves, O., Sabata, L., Chantant, M., Eicker, U., 1998. Large grid-connected hybrid PV system integrated in public building. Progress in Photovoltaics: Research and Applications 6, 453-464.

Longrigg, P., 1982. D.C. to A.C. inverters for photovoltaics. Solar Cells 6 , 343-356.

Lorenzo, E., Narvarte, L., 2000. On the usefulness of stand-alone PV sizing methods. Progress in Photovoltaics: Research and Applications $8,391-409$.

Louche, A., Notton, G., Poggi, P., Peri, G., 1994. Global approach for an optimal grid connected PV system sizing. In: 12th European Photovoltaic Solar Energy Conference, April, Amsterdam, The Netherlands, pp. 1638-1641.

Luque, A., Sala, G., Araújo, G.L., Bruton, T., 1995. Cost reducing potential of photovoltaic concentration. International Journal of Solar Energy 16, 179-198.

Maafi, A., Lounis, B., 2002. Optimizing photovoltaic systems using meteosat VI images. In: World Renewable Energy Congress VII, June 29-July 5, Cologne, Germany.

Maag Jr., C.R., 1977. Outdoor weathering performance of solar electric generators. Journal of Energy 1 (6), 376-381.

Mallick, T.K., Eames, P.C., 2007. Design and fabrication of low concentrating second generation pride concentrator. Solar Energy materials and Solar Cells 91 (7), 697-698.

Mallick, T.K., Eames, P.C., Norton, B., 2002. Asymmetric compound parabolic photovoltaic concentrators for building integration in the UK: an optical analysis. In: World Renewable Energy Congress, 29th June-5th July 2002, Köln, Germany.

Mallick, T.K., Eames, P.C., Norton, B., 2002b. The application of computational fluid dynamics to predict the thermo-fluid behaviour of a parabolic asymmetric photovoltaic concentrator. In: World Renewable Energy Congress, July 2002, Köln, Germany.

Mallick, T.K., Eames, P.C., Hyde, T.J., Norton, B., 2004a. The design and experimental characterisation of an asymmetric compound parabolic photovoltaic concentrator for building façade integration in the UK. Solar Energy 77 (3), 319-327.

Mallick, T.K., Eames, P.C., Hyde, T.J., Norton, B., 2004b. Experimental characterisation of an asymmetric compound parabolic photovoltaic concentrator designed for building integration in the UK. International Journal of Ambient Energy 25 (2), 85-96.

Mallick, T.K., Eames, P.C., Norton, B., 2006. Non-concentrating and asymmetric compound parabolic concentrating building façade integrated photovoltaics: an experimental comparison. Solar Energy 80 (7), 834-849.

Mallick, T.K., Eames, P.C., Norton, B., 2007. Using air flow to alleviate temperature elevations in solar cells within asymmetric compound parabolic concentrators. Solar Energy 81 (2), 173-184.

Mansour, A.F., 1997. Optical efficiency and optical properties of luminescent solar concentrators. Polymer Testing 17, 333-343.

Mansour, A.F., 1998. Outdoor testing of luminescent solar concentrators in a liquid polymer and bulk plate of PMMA. Polymer Testing 17, 153-162.

Mansour, A.F., Salem, A.L., El-Sayed, N.M., Bassyouni, A.H., 1998. Spectroscopy, photostability and optical efficiency of luminescent solar concentrator. Applied Solar Energy 34 (3), 55-62.

Marańda, W., Mey, G.D., Vos, A.D., 1998. Optimization of the masterslave inverter system for grid-connected photovoltaic plants. Energy Conversion and Management 39 (12), 1239-1246.

Marion, B., Atmaram, G., 1990. Seasonal performance of three gridconnected PV systems. In: Conference Record of the IEEE Photovoltaic Specialists Conference, vol. 2. May, Kissimimee, FL, USA, pp. 1030-1037.

Markvart, T., 1994. Solar Electricity. John Wiley \& Sons, USA.

Markvart, T., 2007. Thermodynamics of losses in photovoltaic conversion. Applied Physics Letters 91 (6), 064102.
Markvart, T., Danos, L., Kittidachachan, P., Greef, R., 2005. Detailed balance efficiency of ideal single-stage fluorescent collectors. In: 20th European Photovoltaic Solar Energy Conference, Barcelona, Spain, 171-174.

Martin, N., Ruiz, J.M., 2001. Calculation of the PV modules angular losses under field conditions by means of an analytical model. Solar Energy Materials and Solar Cells 70, 25-38.

Masini, A., Frankl, P., 2002. Forecasting the diffusion of photovoltaic systems in southern Europe: a learning curve approach. Technological Forecasting and Social Change 70, 39-65.

Matsuoka, T., Yagi, H., Waki, Y., Honma, K., Sakai, S., Ohnishi, M., Kawata, H., Nakano, S., Kuwano, Y., 1990. A new solar cell roofing ttle. Solar Cells 29, 361-368.

Maurus, H., Schmid, M., Blersch, B., Lechner, P, Schade, H., 2004. PV for Buildings, ReFocus, December, pp. 22-27.

Maycock, P.D., 1997. Cost reduction in PV manufacturing impact on grid-connected and building- integrated markets. Solar Energy Materials and Solar Cells 47, 37-45.

Meier, C., Hasler, A., 1992. Solar tile: a special PV-module integrated in clay tile roofs. In: 11th European Photovoltaic Solar Energy Conference, October, Montreux, Switzerland, pp. 1664-1667.

Micic, O.I., Cheong, H.M., Fu, H., Zunger, A., Sprague, J.R., Mascarenhas, A., Nozik, A.J., 1997. Size-dependent spectroscopy of InP quantum dots. Journal of Physical Chemistry B 101, 4904-4912.

Micic, O.I., Jones, K.M., Cahill, A., Nozik, A.J., 1998. Optical, electronic and structural properties of uncoupled and close-packed arrays of InP quantum dots. Journal of Physical Chemistry B 102, 9791-9796.

Miguel, A.D., Bilbao, J., Cazorro, J.R.S, Martin, C., 2002. Performance analysis of a grid-connected PV system in a rural site in the Northwest of Spain. In: World Renewable Energy Congress VII, July, Cologne, Germany.

Miller, W., Brown, E., Livezey, R.J., 2005. Building-integrated photovoltaics for low-slope commercial roofs. ASME Journal of Solar Energy Engineering 127, 307-313.

Mills, D.R., Giutronich, J.E., 1978. Asymmetrical non-imaging cylindrical solar concentrators. Solar Energy 20, 45-55.

Mills, D.R., Giutronich, J.E., 1979. New ideal concentrators for distant radiation sources. Solar Energy 20 (1), 45-55.

Molenbroek, E.C., Leenders, F., Kil, A.J., Hoekstra, K.J., Deege, P, Schoen, A.J.N., 1998. Field experience with grid connected, roof integrated amorphous silicon PV systems in the Netherlands. In: 2nd World Conference and Exhibition on Photovoltaic Solar Energy Conversion, July, Vienna, Austria, pp. 2583-2586.

Mondol, J.D., Yohanis, Y.G., Smyth, M., Norton, B., 2005. Long-term validated simulation of a building integrated photovoltaic system. Solar Energy 78, 163-176.

Mondol, J.D., Yohanis, Y.G., Norton, B., 2006a. Optimal sizing of array and inverter for grid-connected photovoltaic systems. Solar Energy 80, $1517-1539$.

Mondol, J.D., Yohanis, Y., Smyth, M., Norton, B., 2006b. Long term performance analysis of a grid connected photovoltaic system in Northern Ireland. Energy Conversion and Management 47, 2925-2947.

Mondol, J.D., Yohanis, Y.G., Norton, B., 2007a. Comparison of measured and predicted long term performance of grid a connected photovoltaic system. Energy Conversion and Management 48, 10651080.

Mondol, J.D., Yohanis, Y.G., Norton, B., 2007b. The impact of array inclination and orientation on the performance of a grid-connected photovoltaic system. Renewable Energy 32, 118-140.

Mondol, J.D., Yohanis, Y.G., Norton, B., 2008. Solar radiation modelling for the simulation of photovoltaic systems. Renewable Energy 33, $1109-1120$.

Mootz, F., Bezian, J.J., 1996. Numerical study of a ventilated façade panel. Solar Energy 57 (1), 29-36.

Mosfegh B., Sandberg M., Bloem J, Ossenbrink J.H., 1995. Analysis of fluid flow and heat transfer within the photovoltaic façade on the Elsa building. JRC Ispra. In: Proceedings of the 13th European PV Solar Energy Conference, Nice, France, pp. 2215-2217. 
Mosfegh, B., Sandberg, M., 1998. Flow and heat transfer in air gap behind photovoltaic panels. Renewable and Sustainable Energy Reviews 2, 287-301.

Mosko, N., Niephaus, D., 1995. Bypass support system designed as an electrical distribution frame and a basic triangle solar cell module for constructing solar power plants. In: 13th European Photovoltaic Solar Energy Conference, vol. 1. October, Nice, France, pp. 537-538.

Mukadam, K., Matas, A., Alonso, M, Pottbrock, R., 1995. The 1 MW photovoltaic plant in Toledo-Spain first operational results and experience. In: 13th European Photovoltaic Solar Energy Conference, October, Nice, France, pp. 1770-1773.

Muller, A.N., Affolter, P., Bonvin, J., Gay, J.B, Roecker, C., 1996. The DEMOSITE and PV building integration activities. In: Proceedings of 4th European Conference on Solar Energy in Architecture and Urban Planning, March, pp. 575-578.

Mullick, S.C., Malhotra, A., Nanda, S.K., 1987. Optimisation of the seasonally adjusted solar concentrator by the discrete maximum principle. Solar and Wind Technology 4 (2), 195-199.

Murata, K., Yagiura, T., Takeda, K., Tanaka, M., Kiyama, S., 2003. New type of photovoltaic module integrated with roofing (highly fireresistant PV title). Solar Energy Materials and Solar Cells 75, 647-653.

Muselli, M., Poggi, P., Notton, G., Louche, A., 1998. Improved procedure for stand-alone photovoltaic system sizing using meteosat satellite images. Solar Energy 62 (6), 429-444.

Muselli, M., Notton, G., Poggi, P., Louche, A., 1999. Computer-aided analysis of the integration of renewable-energy systems in remote areas using a geographical-information system. Applied Energy 63, 141-160.

Nakamura, H., Yamada, T., Sugiura, T., Sakuta, K., Kurokawa, K., 2001. Data analysis on solar irradiance and performance characteristics of solar modules with a test facility of various tilted angles and directions. Solar Energy Materials and Solar Cells 67, 591-600.

Nann, S., Emery, K., 1992. Spectral effects on PV-device rating. Solar Energy Materials and Solar Cells 27, 189-216.

Narvarte, L., Lorenzo, E., 1996. On the sizing of solar home systems. EuroSun'96, 1475-1478.

Nath, P., Vogeli, C., Singh, A., Call, J., 1994. Amorphous silicon alloybased roof integrated photovoltaic systems. In: Conference Record of the IEEE Photovoltaic Specialists Conference, vol. 1. December, Waikoloa, HI, USA, pp. 966-968.

Nath, P., Vogeli, C., Singh, A., Slominsky, L., Call, J., Walters, M., Guha, S., 1998. Amorphous silicon alloy based roof integrated PV roofing elements. In: 2nd World Conference and Exhibition on Photovoltaic Solar Energy Conversion, July, Vienna, Austria, pp. 2538-2541.

Negro, E., 1995. On PV simulation tools and sizing techniques: a comparative analysis towards a reference procedure. In: 13th European Photovoltaic Solar Energy Conference, October, Nice, France, pp. 687-691.

Nieuwenhout, F.D.J., Dijk, A.V., Lasschuit, P.E., Roekel, G.V., Dijk, V.A.P., Hirch, D., Arriaza, H., Hankins, M., Sharma, B.D., Wadc, H., 2001. Experience with solar home systems in developing countries: a review. Progress in Photovoltaics: Research and Applications 9, 455474.

Nishikawa, Y., Tezuka, T., Kang, M., 1992. Economic evaluation of a photovoltaic power generation introduced into an electric power system with electricity storage. Electrical Engineering in Japan 112 (4), 107-112.

Nitta, Y., Hatukaiwat, T., Yamawaki, T., Matumura, Y., Mizukami, S., 1994. Development of photovoltaic module integrated with roofing materials (heat insulated roof panel). In: Conference Record of the IEEE Photovoltaic Specialists Conference, vol. 1. December, Waikoloa, HI, USA, pp. 973-976.

Nofuentes, G., Almonacid, G., 1998. An approach to the selection of the inverter for architecturally integrated photovoltaic grid-connected systems. Renewable Energy 15, 487-490.

Nofuentes, G., Almonacid, G., 1999. Design tools for the electrical configuration of architecturally integrated PV in buildings. Progress in Photovoltaics: Research and Applications 7, 475-488.
Noh, H., Lee, D., Hyun, D., 2002. An improved converter with curren compensation method for small sealed PV applications. In: Proceedings of the 28th Annual Conference of the IEEE Industrial Electronics Society, vol. 2, November, Sevilla, Spain, pp. 1113-1118.

Nordman, T., Dürr, M., Frölich, A., 1997. The 32 kW PV installation on the grain silo of the stadtmühle CMZ: the first installation for the zurich solar power exchange. In: 14th European Photovoltaic Solar Energy Conference, Barcelona, Spain.

Nordmann, T., 1997. Photovoltaic building and infrastructure integration: the European experience of improvement in technology and economics. Solar Energy Materials and Solar Cells 47, 213-226.

Norton, B., 1992. Solar Energy thermal Reviews. Springer, Heidelburg, Germany.

Norton, B., Eames, P.C., Yadav, Y.P., 1991. Symmetric and asymmetric linear compound parabolic concentrating solar energy collectors: the state-of-the-art in optical and thermo-physical analysis. International Journal of Ambient Energy 12 (4), 171-191.

Norton, B., Hobday, R.A., Lo, S.M.G., 1992. Thermosyphoning air apNels. Advances in Solar Energy 7, 495-571.

Notton, G., Muselli, M., Poggi, P., Louche, A., 1996. Autonomous photovoltaic systems: influenced of some parameters on the sizing: simulation timestep, input and output power profile. Renewable Energy 7, 353-369.

Okuda, N., Yagiura, T., Morizane, M., Nakamura, N., Ohinshi, M., Nakano, S., 1994. A new type of photovoltaic shingle. In: Conference Record of the IEEE Photovoltaic Specialists Conference, vol. 1, December 5-9, Waikoloa, HI, USA, pp. 1008-1011.

Oladiran, M.T., 1995. Mean global radiation captured by inclined collectors at various surface azimuth angles in Nigeria. Applied Energy 52, 317-330.

Oliver, M., Jackson, T., 1999. The market for solar photovoltaics. Energy Policy 27 (7), 371-385.

Oliver, M., Jackson, T., 2000. The evolution of economic and environmental cost for crystalline silicon photovoltaics. Energy Policy 28 1011-1021.

Oliver, M., Jackson, T., 2001. Energy and economic evaluation of building-integrated photovoltaics. Energy 26, 431-439.

Omer, S.A., Wilson, R., Riffat, B., 2002. Comparative design and monitoring of PV systems on a domestic and an educational building. In: World Renewable Energy Congress VII, July, Cologne, Germany.

Omer, S.A., Wilson, R., Riffat, S.B., 2003. Monitoring results of two examples of building integrated PV (BIPV) systems in the UK. Renewable Energy 28 (9), 1387-1399.

Oshiro, T., Nakamura, H., Imataki, M., Sakuta, K., Kurokawa, K., 1997. Practical value of various parameters for PV system design. Solar Energy Materials and Solar Cells 47, 177-187.

Ossenbrink, H.A., Rigolini, L., Chehab, O., van der Venne, O., 1994. Building integration of an amorphous photovoltaic façade. In: Conference Record of the IEEE Photovoltaic Specialists Conference, vol. 1. December 5-9, Waikoloa, HI, USA, pp. 770-773.

Otani, K., Kurokawa, K., Tsuda, I., Saitoh, T., Horigome, T., 1994. Estimation of ground albedo by GMS images for solar irradiation monitoring. Solar Energy Materials and Solar Cells $35,395-400$

Paatero, J.V., Lund, P., 2006. Effects of large-scale photovoltaic power integration on electricity distribution networks. Renewable Energy 32, 216-234.

Pal, D., Joshi, Y.K., 1997. Application of phase change materials for thermal control of plastic quad flat packages (PQFP): a computational study. Numerical Heat Transfer, Part A 30, 19-34.

Pal, D., Joshi, Y.K., 1999. Thermal control of horizontally mounted heat sources using phase change materials. In: EEP-26-2, Advances in Electronic Packing-1999, vol. 2. ASME 1999, 1625-1630.

Palomino, G.E., Wiles, J., Stevens, J., Goodman, F., 1997. Performance of a grid connected residential photovoltaic with energy storage. In: 26th IEEE Photovoltaic Specialists Conference, October, Anaheim, CA, $1377-1380$ 
Park, M., Kim, B., Yu, I., 2001a. A study on the simulation scheme for utility interactive PV-generation. In: IEEE International Symposium on Industrial Electronics, vol. 1. June 13-18, Pusan, South Korea.

Park, M., Kim, B., Yu. I., 2001b. A novel simulation method for PV power generation systems using real weather conditions. In: IEEE International Symposium on Industrial Electronics, vol. 1. June, Pusan, South Korea, 526-530.

Pearsall, N.M., Hynes, K.M., Hill, R., 1997. Analysis of operation of the Northumberland building photovoltaic façade. In: 14th European Photovoltaic Solar Energy Conference, July, Barcelona, Spain, 19681971.

Peippo, K., Lund, P.D., 1994a. Optimal sizing of a grid-connected PV systems for different climates and array orientations: a simulation study. Solar Energy Materials and Solar Cells 35, 445-451.

Peippo, K., Lund, P.D., 1994b. Optimal sizing of solar array and inverter in grid-connected photovoltaic systems. Solar Energy Materials and Solar Cells 32, 95-114.

Perez, R., Ineichen, P., Seals, R., 1990. Modelling daylight availability and irradiance components from direct and global irradiance. Solar Energy 44, 271-279.

Perpinan, O., Lorenzo, E., Castro, M.A., Eyras, R., 2008. On the complexity of radiation models for PV energy production calculation. Solar Energy 82, 125-151.

Peterson, A.J., Perez, R., Bailey, B., Elsholz, K., 1999. Operational experience of a residential photovoltaic hybrid system. Solar Energy 65 (4), 227-235.

Pietruszko, S.M., Gradzki, M., 2003. Performance of a grid connected small PV system in Poland. Applied Energy 74, 177-184.

Posbic, J.P., Rever III, W.B., 1998. Economic optimization of building integrated photovoltaic systems. In: Proceedings of the 1998 International Solar Energy Conference, June, Albuquerque, NM, USA, pp. 209-212.

Posnansky, M., Eckmanns, A., 1995. Practical results with cogeneration electricity and heat on building integrated PV-power systems. In: 13th European Photovoltaic Solar Energy Conference, October, pp. 17791782.

Posnansky, M., Hochreutener, H., Gnos, S., 1992. Building integrated photovoltaic systems: example of realized PV roof-and PV façadepower plants with specially conceived PV modules for building integration. In: 11th E.C. Photovoltaic Solar Energy Conference, October, Montreux, Swizerland, pp. 1676-1678.

Posnansky, M., Szacsvay, T., Dütsch, B., Stucki, B., 1997. SUNSLATE ${ }^{\text {TM }}$ - a novel PV-roofing and façade system. In: 14th European Photovoltaic Solar Energy Conference, July, Barcelona, Spain, pp. 1922 1924.

Pratt, R.G., Burdik, J., 1988. Performance of a $4 \mathrm{~kW}$ amorphous-silicon alloy photovoltaic array at Okland Community College, Aurban Hills, Michigan. In: Conference Record of the IEEE Photovoltaic Specialists Conference,vol. 2. September, Las Vegas, NV, USA, pp. 1272-1277.

Preu, R., Kleiss, G., Reiche, K., Bücher, K., 1995. PV-module reflection losses: measurement, simulation and influence on energy yield and performance ratio. In: 13th European Photovoltaic Solar Energy Conference, October, Nice, France, pp. 1465-1468.

Prudhoe, R.K., Doukas, L., 1990. The use of phase change materials (pcms) and vacuum panel heat exchange for energy conservation and thermal stability of electronic equipment enclosures. In: 12th International Telecommunication Energy Conference (INTELEC), Florence, Italy.

Quaschning, V., Hanitsch, R., 1998. Increased energy yield of $50 \%$ at flat roof and field installations with optimized module structures. In: 2 nd World Conference and Exhibition on Photovoltaic Solar Energy Conversion, July, Vienna, Austria, pp. 1993-1996.

Rabl, A., 1976a. Optical and thermal properties of compound parabolic concentrators. Solar Energy 18, 497-511.

Rabl, A., 1976b. Solar concentrators with maximum concentration for cylindrical absorbers. Applied Optics 15 (7), 1871-1873.

Rabl, A., 1985. Active Solar Collectors and Their Applications. Oxford University Press, Oxford, UK.
Rahman, S., Jockell, J., Lahouar, S., 1990. Analysis of the photovoltaic for demand side management. In: 21st IEEE Photovoltaic Specialists Conference, May 21-25, Kissimmee, FL, USA, pp. 809-814.

Rapp, C.F., Boling, N.L., 1978. Luminescent solar concentrators. In: Proceedings of the 13th IEEE Photovoltaic Specialists Conference, pp. 690-693.

Rasmussen, N.E., Branz, H.M., 1981. The dependence of delivered energy on power conditioner electrical characteristics for utility-interactive PV systems. In: 15th IEEE Photovoltaic Specialists Conference, pp. 614 620.

Reda, S.M., 2008. Synthesis and optical properties of CdS quantum dots embedded in silica matrix thin films and their application as luminescent solar concentrators, Acta Materialia 56, 259-264.

Reed, M.A., 1993. Quantum Dots. Scientific American, pp. 98-103.

Reijenga, I.T., Böttger, W.O.J., 1997. Glass roof integrated system De Kleine Aarde Boxel (NL) THERMIE SE 104/93 NL. In: 14th European Photovoltaic Solar Energy Conference, June 30-July 4, Barcelona, Spain, pp. 1887-1890.

Reinders, A.H.M.E., Dijk, V.A.P., Wiemken, E., Turkenburg, E., 1999. Technical and economic analysis of grid-connected PV system by means of simulation. Progress in Photovoltaics: Research and Applications 7, 71-82.

Reisfeld, R., Jorgensen, C.K., 1982. Luminescent solar concentrators for energy conversion. Structure and Bonding 49, 1-36.

Reisfeld, R., Eyal, M., Chernyak, V., Zusman, R., 1988. Luminescent solar concentrators based on thin films of polymethylmethacrylate on a polymethlmethacrylate support. Solar Energy Materials 17, 439-455.

Richards, B.S., 2006. Luminescent layers for enhanced silicon solar cell performance: down-conversion. Solar Energy Materials and Solar Cells 90 (9), 1189-1207.

Richards, B.S., Shalav, A., Corkish, R.P., 2004. A low escape-cone loss luminescent concentrator. In: 19th EC Photovoltaic Solar Energy Conference, Paris, France, pp. 113-116.

Rie, H., Sprau, P., 1992. Design considerations for the PV generator/ inverter matching in grid connected systems. In: 11th European Photovoltaic Solar Energy Conference, October, Montreux, Switzerland, pp. 1377-1378.

Roberts S., Patterson M.H., Bruton T.M., 2001. Trends in photovoltaic technology. In: Proceedings of Renewable Energy in Maritime Island Climates, Conference C76 of the Solar Energy Society, Belfast, UK.

Román, E., Alonso, R., Ibanez, P., Elorduizapatarietxe, S., Goitia, D., 2006. Intelligent PV module for grid-connected PV systems. IEEE Trans on Industrial Electronics 53, 1066-1073.

Román, E., Martinez, V., Jimeno, J.C., Alonso, R., Ibanez, P., Elorduizapatarietxe, S., 2008. Experimental results of controlled PV module for building integrated systems. Solar Energy 82, 471-480.

Roo Ons, M.J., Shynu, S.V., Ammann, M., McCormack, S.J., Norton, B., 2007. Planar antenna with integrated solar cells for antanomous communication systems. In: European Photovoltaic Solar Energy Conference, Milan, pp. 333-336.

Roo Ons, M.J., Shynu, S.V., Ruvie, G., Ammann, M., McCormack, S.J., Norton, B., 2008. Polycrystalline solar cells as reflector for dipole antenna. In: European Solar Energy Conference, Valencia, Spain.

Rowan, B.C., Gallagher, S.J., Doran, J.D., Norton, B., 2006. Performance evaluation of small-scale quantum dot solar concentrators with different quantum dot densities. In: Proceedings of the 2nd International Renewable Energy in Maritime Climates Conference, April, Dublin, Ireland, pp. 279-284.

Rowan, B.C., Gallagher, S.J., Doran, J.D., Norton, B., 2007. Indoor charactersiation of small-scale quantum dot solar concentrators of various geometries and QD concentrations. In: Proceedings of the 21st European Photovoltaic Solar Energy Conference and Exhibition, September, Dresden, Germany(CD-ROM).

Rüther, R., 1998. Experiences and operational results of the first gridconnected, building integrated, thin film photovoltaic installation in Brazil. In: 2nd World Conference and Exhibition on Photovoltaic Solar Energy Conversion, July, Vienna, Austria, pp. 2655-2658. 
Rüther, R., Dacoregio, M.M., 2000. Performance assessment of a $2 \mathrm{~kW}_{\mathrm{p}}$ grid-connected, building integrated, amorphous silicon photovoltaic installation in Brazil. Progress in Photovoltaics: Research and Applications 8, 257-266.

Sala, M., Brissoni, M., Franci, G., 1995. Network re-integrated bus shelter in regional development. In: 13th European Photovoltaic Solar Energy Conference, vol. 1. October 23-27, Nice, France, pp. 533-536.

Sala, M., Grassi, A., Fusco, P., 1996. PV covered window blinds as a means of large-scale indoor application of photovoltaic energy. In: Proceedings of 4th European conference on Solar Energy in Architecture and Urban Planning, March, Berlin, Germany, pp. 617-620.

Salem, A.I., Mansour, A.F., El-Sayed, N.M., Bassyouni, A.H., 2000 Outdoor testing and solar simulation for oxazine 750 laser dye luminescent solar concentrator. Renewable Energy 20, 95-107.

Salyer, I.O., Sircar, A.K., 1990. Phase change materials for heating and cooling of residential buildings and other applications. In: Proceedings of the 25th Intersociety Energy Conversion Engineering Conference, vol. 1. August, Reno, NV, USA, pp. 236-241.

Salyer, I.O., Sircar, A.K., 1997. A review of phase change materials research for thermal energy storage in heating and cooling applications at the University of Dayton from 1982 to 1996. International Journal of Global Energy Issues 9.

Sandberg, M., Mosfegh, B., 1996. Investigation of fluid flow and heat transfer in a vertical channel heated from one side by PV elements-part II, experimental study. In: Proceedings of the World Renewable Energy Conference, Denver, USA, pp. 254-258.

Sandnes, B., Rekstad, J., 2002. A photovoltaic (PV/T) collector with a polymer absorber plate; experimental study and analytical model. Solar Energy 72, 63-73.

Sattler, K., 2002. The energy gap of clusters nanoparticles and quantum dots, Handbook of Thin Films. In: Nanomaterials and Magnetic Thin Films, vol. 5. Academic Press, USA.

Schalkwijk, van M., Schoen, T., Schmidt, H., Toggweiler, P., 1995. Overview and results of IEA-SHCP-TASK 16 demonstration buildings. In: 13th European Photovoltaic Solar Energy Conference, October, Nice, France, pp. 2141-2144.

Schalkwijk, van M., Kil, A.J., Weiden, van der T.C.J., Paes, P.S., 1997. Undersizing of inverters: modelling and monitoring results of $15 \mathrm{PV} /$ Inverter units in Portugal and the Netherlands. In: 14th European Photovoltaic Solar Energy Conference, July, Barcelona, Spain, pp. 2229-2232.

Schaub, P., Mermoud, A., Guisan, O., 1994. Evaluation of the differen losses involved in two photovoltaic systems. In: 12th European Photovoltaic Solar Energy Conference, April, Amsterdam, Netherlands, pp. 859-862.

Schilla, T., Hill, R., Pearsall, N., Bucher, G., 1997. PVNETSIM a versatile simulation software based on the design centre programs schematics, PSPICE and PROBE. In: 14th European Photovoltaic Solar Energy Conference, July, Barcelona, Spain, pp. 1558-1561.

Schmid, J., 1992. PV in Buildings. In: Proceedings of 11th E.C. Photovoltaic Solar Energy Conference, Montreux, Switzerland, pp. 1659-1663.

Schmitt, W., 2002. Modeling and simulation of photovoltaic hybrid energy systems optimization of sizing and control. In: 29th IEEE Photovoltaic Specialists Conference, May, New Orleans, Louisiana, pp. $1656-1659$.

Schroeder, C.C., Kreider, J.F., 1998. Field evaluation of a grid-connected PV system. In: International Solar Energy Conference, June, Albuquerque, NM, USA, pp. 213-216.

Schüler, A., Python, M., Valle del Olmo, M., de Chambrier, E., 2007. Quantum dot containing nanocomposite thin films for photoluminescent solar concentrators. Solar Energy 81 (9), 1159-1165.

Scott, R.D., Lord, B.E., Crick, F.J., Louineau, J.P., Noble, R., Anderson, D., 1992. A study of the integration of PV modules into building cladding components in the UK. In: 11th European Photovoltaic Solar Energy Conference, October, Montreux, Switzerland, pp. 1491-1494.
Shalav, A., Richards, B.S., Green, M.A., 2007. Luminescent layers for enhanced silicon solar cell performance: up-conversion. Solar Energy Materials and Solar Cells 91 (9), 829-842.

Sharma, V.K., Colangelo, A., Spagna, G., 1995. Photovoltaic technology: basic concepts, sizing of a stand alone photovoltaic system for domestic applications and preliminary economic analysis. Energy Conversion and Management 36 (3), 161-174.

Shaw, N.C., Wenham, S.R., 2000. Design of a novel static concentrator lens utilising total internal reflection surfaces. In: 16th European Photovoltaic Solar Energy Conference, Glasgow, UK, pp. 2342-2345.

Shaw, M., Scott, R., Crick, F.J., Rafter, P., Parr, A.E., Pearsall, N.M., Young, G., 1995. The concept of the photovoltaic ventilated façade. In Proceedings of 13th E.C. Photovoltaic Solar Energy Conference, 2327th October, Nice, France, pp. 2209-2212.

Shinjo, F., 1994. R\&D of photovoltaic modules integrated with construction material. In: Conference Record of the IEEE Photovoltaic Specialists Conference, vol. 1. December, Waikoloa, HI, USA, pp. 778-780.

Shinohara, H., Kimoto, K., Itami, T., Ambo, T., Okado, C., Nakajima, K., Hojo, S., Ioka, S., Kuniyoshi, M., 1992. Development of a residential use, utility interactive $\mathrm{PV}$ inverter with high frequency isolation. Solar Energy Materials and Solar Cells 35, 429-436.

Sholin, V.J., Olson, D., Carter, S.A., 2007. Semiconducting polymers and quantum dots in luminescent solar concentrators for solar energy harvesting. Journal of Applied Physics 101, 123114.

Shrestra, G.B., 1998. Consideration of insolation characteristics in sizing stand-alone PV stations. Proceedings of the International Conference on Energy Managernent and Power Delivery, EMPD 2, 631-636.

Sick, F., Erge, T., 1996. Photovoltaics in Buildings: A Design Handbook for Architects and Engineers. James \& James Limited, London UK.

Sidrach-de-Cardona, M., López, L.M., 1998. Evaluation of a gridconnected photovoltaic system in Southern Spain. Renewable Energy $15,527-530$.

Sidrach-de-Cardona, M., López, L.M., 1999. Performance analysis of a grid-connected photovoltaic system. Energy 24, 93-102.

Simmons, A.D., Infield, D.G., 1996. Grid-connected amorphous silicon photovoltaic array. Progress in Photovoltaics: Research and Applications 4, 381-388.

Simmons, A.D., Infield, D.G., Redi, P., Lori, L., Martin, N., 2000. Optimisation of inverter for building integrates photovoltaics. In: 16th European Solar Energy Conference, May, Glasgow, UK, pp. 24262429.

Simones, H.M., Baert, D.H., Mey, G.D., 1984. Optimal system sizing in grid-connected photovoltaic applications. Commission of the European Communities (Report), 467-471.

Slooff, L.H., Kinderman, R., Burgers, A.R., van Roosmalen, J.A.M., Büchtemann, A., Danz, R., Meyer, T.B., Chatten, A.J., Farrell, D., Barnham, K.W.J., 2006. The luminescent concentrator illuminated. In: Conference in Proceedings of Photonics Europe, Strasbourg.

Smiley, E.W., Stamenic, L., 2002. Optimization of building integrated photovoltaic systems. In: 29th IEEE Photovoltaic Specialists Conference, May, New Orleans, LA, United States, pp. 1501-1503.

Smith, R.H., 1976. Conference on Heliotechnique and Development. Development Analysis Associates Inc., Cambridge, Massachusetts. USA, p. 251.

Snow, M., Jones, P., Prasad, D.K., 1999. Photovoltaics (PV) modelling for cities: a GIS-building integrated PV (BIPV) simulation approach. ISES Solar World Congress 2, 147-155.

Soleimani, E.A., Farhangi, S., Zabihi, M.S., 2001. The effect of tilt angle, air pollution on performance of photovoltaic systems in Tehran. Renewable Energy 24, 459-468.

Sopitpan, S., Changmuang, P., Panyakeow, S., 2001. Monitoring and data analysis of a PV system connected to a grid for home applications. Solar Energy Materials and Solar Cells 67, 481-490.

Soras, C., Makios, V., 1988. A novel method for determining the optimum size of stand-alone photovoltaic systems. Solar Cells 25, 127-142.

Steinhardt, F., Heilscher, G., Pfatischer, R. 1998. 200 kW roof integrated PV power station 'A.uf dem Kruge', Bremen. In: 2nd World Confer- 
ence and Exhibition on Photovoltaic Solar Energy Conversion, July, Vienna, Austria, pp. 2534-2537.

Stellbogen, D., 1992. Intelligent monitoring-online-simulation for the detection of faults in PV array. In: 11th European Photovoltaic Solar Energy Conference, October, Montreux, Switzerland, pp. 1368-1371.

Stocker, F., Tarchini, F., Reindimella, G., 1992. ECOPOWER a modular high efficient photovoltaic grid connected PWM-inverter. In: 11th E.C. Photovoltaic Solar Energy Conference, October, Montreux, Switzerland, pp. 1171-1174.

Strong, S., 1996a. The dawning of solar architecture. Sun World 20 (1), 35.

Strong, S.J. 1996b. World overview of building-integrated photovoltaics. In: Conference Record of the IEEE Photovoltaic Specialists Conference, May, Washington, D.C., pp. 1197-1202.

Sugiura, T., Yamada, T., Nakamura, H., Umeya, M., Sakuta, K., Kurokawa, K., 2003. Measurements, analyses and evaluation of residential PV systems by Japanese monitoring program. Solar Energy Materials and Solar Cells 75, 767-779.

Sukamongkol, Y., Chungpaibulpatana, S., Ongsakul, W., 2002. A simulation model for predicting the performance of a solar photovoltaic system with alternating current loads. Renewable Energy 27, 237258.

Suzuki, R., Kawamura, H., Yamanaka, S., Kawamura, H., Ohno, H., Naito, S., 2002. Loss factor affecting power generation efficiency of a PV moduleIn: 29th IEEE Photovoltaic Specialists Conference, May, New Orleans, LA, United States, pp. 1557-1560.

Swiegers, W., Enslin, J.H.R., 1998. An integrated maximum power point tracker for photovoltaic panels. In: IEEE International Symposium on Industrial Electronics, vol. 1. July, Pretoria, SA, pp. 40-44.

Takashima, T., Tanaka, T., Amano, M., Ando, Y., 2000. Maximum output control of photovoltaic (PV) array. In: Proceedings of the Intersociety Energy Conversion Engineering Conference, vol. 1. July, Las Vegus, USA, pp. 380-383.

Taleb, A.M., 2002. Self absorption treatment for the luminescent solar concentrators. Renewable Energy 26, 137-142.

Tiwari, A., Roman, V., Tiwari, G.N., 2007. Embodied energy analysis of hybrid photovoltaic thermal $(\mathrm{PV} / \mathrm{T})$ water collector. International Journal of Ambient Energy 28, 181-188.

Tonui, J.K., Tripanagnostopoulos, Y., 2008. Performance improvement of PV/T solar collectors with natural air flow operation. Solar Energy $82,1-12$.

Townsend, T.U., Whitaker, C.M., 1997. Measured vs. ideal insolation on PV structures. In: 26th IEEE Photovoltaic Specialists Conference, October, Anaheim, CA, pp. 1201-1204.

Townsend, T., Whitaker, C., Farmer, B., Wenger, H., 1994. A new performance index for PV system analysis. In: Conference Record of the IEEE Photovoltaic Specialists Conference, vol. 1. December, Waikoloa, HI, USA, pp. 1036-1039.

Toyokawa, S., Uehara, S., 1997. Overall evaluation for R\&D of PV modules integrated with construction materials. In: Conference Record of the IEEE Photovoltaic Specialists Conference, October, Anaheim, CA, USA, pp. 1333-1336.

Travers, D., Watt, M., MacGill, I., Kaye, J., Kunzi, S., Spooner, T., 1998. Evaluation tool for building integrated photovoltaic systems. In: 2nd World Conference and Exhibition on Photovoltaic Solar Energy Conversion, July, Vienna, Austria, pp. 2579-2582.

Tsalides, P., Thanailakis, A., 1985. Direct computation of the array optimum tilt angle in constant-tilt photovoltaic systems. Solar Cells 14, 83-94.

Ubertini, S., Desideri, U., 2003. Performance estimation and experimental measurement of a photovoltaic roof. Renewable Energy 28, 1833-1850.

Ueda, Y., Oozeki, T., Kurokawa, K., Itou, T., Kikamura, K., Miyamoto, Y., Yokota, M., Sugihara, H., 2006. Quantitative analysis of output loss due to restriction for grid-connected PV systems. Electrical Engineering in Japan 158, 9-19.

Uehara, S., 1997. Overall evaluation for R\&D of PV modules integrated with construction materials. In: 14th European Photovoltaic Solar Energy Conference, Barcelona, Spain, pp. 1871-1874.
Uematsu, T., Yazawa, Y., Joge, T., Kokunai, S., 2001a. Fabrication and characterisation of a flat-plate static concentrator photovoltaic module. Solar Energy Materials and Solar Cells 67, 425-434.

Uematsu, T., Yazawa, Y., Miyamura, Y., Muramatsu, S., Ohtsuka, H., Tsutsui, K., Warabisako, T., 2001b. Static concentrator photovoltaic module with prism array. Solar Energy Materials and Solar Cells 67, 415-423.

Uematsu, T., Yazawa, Y., Tsutsui, K., Miyamura, Y., Ohtsuka, H., Warabisako, T., Joge, T., 2001c. Design and characterisation of flatplate static-concentrator photovoltaic modules. Solar Energy Materials and Solar Cells 67, 441-448.

Uematsu, T., Tsutsui, K., Yazawa, Y., Warabisako, T., Araki, I., Eguchi, Y., Joge, T., 2003. Development of bifacial PV cells for new applications of flat-plate modules. Solar Energy Materials and Solar Cells 75, 557-566.

van Dyk, E.E., Meyer, E.L., Voster, F.J., Leitch, A.W.R., 2002. Longterm monitoring of photovoltaic devices. Renewable Energy 25, 183197.

Van Kerchauer, E., Beaucamie, G., 2005. Back-contact solar cells: a review. Progress in Photovoltaics: Research and Application 14, 107123.

van Sark, W.G.J.H.M., De Mello Donegá, C., Harkisoen, C., Kinderman, R., van Roosmalen, J.A.M., Schropp, R.E.I., Lysen, E.H., 2004. Improvement of spectral response of solar cells by deployment of spectral converters containing semiconductor nanocrystals. In: Proceedings of the 19th European PV Solar Energy Conference and Exhibition, 7-11 June 2004, Paris.

van Sark, W.G.J.H.M., 2006. Optimization of the performance of solar cells with spectral down converters. In: Proceedings of the 21st European Photovoltaic Solar Energy Conference and Exhibition, Dresden.

Veltman, A.T., Wiecherink, R., Burgel, R.J., de Haan, S.W.H., Wildenbeest, E., Cervenka, S., Cloin, J., 1992. Test results of inverters for grid connected photovoltaic system. In: 11th E.C. Photovoltaic Solar Energy Conference, October, Montreux, Swizerland, pp. 1175-1179.

von Bussue, H.B., Müller, H.F.O., Runkel, S., 1996. Photovoltaicintegration of a new technology in architecture. In: Proceedings of 4th European Conference on Solar Energy in Architecture and Urban Planning, March, pp. 551-553.

Waide, P.A., Norton, B., 2003. Variation of insolation transmission with glazing plane position and shy conditions. ASME Journal of Solar Energy Engineering 125, 182-189.

Wambach, K., 1998. New integrated photovoltaic roof elements into residential buildings. In: 2nd World Conference and Exhibition on Photovoltaic Solar Energy Conversion, July, Vienna, Austria, pp. 2609-2612.

Wang, Y., Tian, W., Zhu, L., Ren, J., Liu, Y., Zhang, J., 2006. Interactions between building integrated photovoltaics and microclimate in urban environments. ASHE Journal of Solar Energy Engineering 128, 168-172.

Watt, M., Kaye, R.J., Travers, D., MacFill, I., 1997. Assessing the potential for PV in buildings. In: 14th European Photovoltaic Solar Energy Conference, July, Barcelona, Spain, pp. 1879-1882.

Watt, M., Kaye, R.J., Travers, D., MacGill, I., 1998a. Assessing the potential for pv in buildings. In: 14th European Photovoltaic Solar Energy Conference and Exhibition, Barcelona, Spain, pp. 18791882.

Watt, M., Outhred, H., Ellis, M., Thorp, D., 1998b. Strategies for PV in competitive electricity markets. In: 2nd World Conference and Exhibition on Photovoltaic Solar Energy Conversion, Vienna, Austria, pp. 3369-3372.

Watt, M., Kaye, J., Travers, D., MacGill, I., Prasad, D., Thomas, P.C., Fox, L., Jansen, S., 1999. Opportunities for the Use of Building Integrated Photovoltaics in NSW. New South Wales, Australia.

Weidele, Th., Pruschek, R., Rauh, H.U., 1996. Economic optimization of grid connected PV system. Eurosun'96 934, 939.

Weinmann, D., 1997. Transport Properties of Quantum Dots. PhD Thesis. University of Hamburg, Germany. 
Welford, W.T., 1978. The Optics of Nonimaging Concentrators: Light and Solar Energy. Academic Press, New York, USA.

Welford, W.T., Winston, R., 1978. The optics of Non-Imaging Concentrators. Academic Press, London, UK.

Welford, W.T., Winston, R., 1979. Two-dimensional nonimaging concentrators with refracting optics. Journal of the Optical Society of America 69 (6), 917-919.

Wenham, S.R., Bowden, S., Dickinson, M., Largent, R., Jordan, D., Honsberg, C.B., Green, M., 1995. Prototype photovoltaic roof tiles. In: 13th European Photovoltaic Solar Energy Conference, Nice, France.

Wennerberg, J., Kessler, J., Hedström, J., Stolt, L., Karlsson, B., Rönnelid, M., 2000. Thin film PV modules for low-concentrating systems. Solar Energy 69 (1-6), 243-255.

Whitaker, C., Real, M., 1999. The impact of efficiency on area-related system costs. Progress in Photovoltaics: Research and Applications 7, 199-207.

Wilk, H., 1994. $200 \mathrm{~kW}$ photovoltaic rooftop programme in austria: first operational results and lessons learned. In: Proceedings of 12 th E.C. Photovoltaic Solar Energy Conference, Amsterdam, Netherlands, pp. 923-927.

Wills, R.H., Hall, F.E., Strong, S.J., Wohlgemuth, J.H., 1996. The AC photovoltaic module. In: 25th IEEE Photovoltaic Specialists Conference, vol. 1. May, Washington, D.C., USA, pp. 1231-1234.

Wills, R.H., Bulawka, A., Krauthamer, S., Posbic, J.P., 1997. The AC photovoltaic module concept. In: Proceedings of the Intersociety Energy Conversion Engineering Conference, vols. 3-4. August, Honolulu, HI, USA, pp. 1562-1563.

Wilshaw, A.R., Gonzales, N.J., Blewett, T., Pearsall, N.M., 1995. Temperature and shading effects on the performance of a building integrated photovoltaic array in Newcastle upon Tyne. In: Proceedings of 13th E.C. Photovoltaic Solar Energy Conference, Nice, France, pp. 664-667.

Wilshaw, A.R., Pearsall, N.M., Hill, R., 1997. The Northumberland building - an assessment of mismatch losses in the photovoltaic facade. In: Proceedings of the 14th European PV Solar Energy Conference, Barcelona, Spain, pp. 937-940.

Winston, R., 1974. Principles of solar concentrators of a novel design. Solar Energy 16, 89-95.

Winston, R., 1975. Development of the compound parabolic collector for photo-thermal and photo-voltaic applications. In: Proceedings of optics in solar energy utilization, 21-22 August, SPIE 68, San Diego, CA, USA, pp. 136-144.

Winston, R., 1980. Light collection within the framework of geometrical optics. Journal of the Optical Society of America 60 (2), 245-247.

Winston, R., Hinterberger, H., 1995. Principles of cylindrical concentrators for solar energy. Solar Energy 17, 255-258.

Winston, R., Welford, W.T., 1978. Two-dimensional concentrators for inhomogeneous media. Journal of the Optical Society of America 68 (3), 289-291.

Wittwer, V., Stahl, W., Goetzberger, A., 1984. Fluorescent planar concentrators. Solar Energy Materials 11, 187-197.

Wood, J.R., Long, J.F., 1978. Performance tests of organic dyes in a planar solar concentrator with ribbon photovoltaic cells. In: Proceedings of the 13th Photovoltaic Specialists Conference IEEE, pp. 11581159.

Woolf, J., 2003. Renew: a renewable energy design tool for architects. Renewable energy 28, 1555-1561.

Wouters, P., Vandaele, L., Bloem, H., 1996. Hybrid photovoltaic building facades: the challenged for an integrated overall performance evaluation. In: Proceedings of 4th European Conference on Solar Energy in Architecture and Urban Planning, March, pp. 579-582.

Woyte, A., van den Keybus, J., Belmans, R., Nijs, J., 2000. Gridconnected photovoltaics in the urban environment - an experimental approach to system optimisation. In: IEEE Proceedings for Power Electronics and Variable Speed Drives, September, pp. 548-553.

Yagiura, T., Morizane, M., Murata, K., Uchihashi, K., Tsuda, S., Nakano, S., Ito, T., Omoto, S., Yamashita, Y., Tamakawa, H.,
Fujiwara, . Exchangeable PV shingle. Solar Energy Materials and Solar Cells 47, 227-233.

Yamawaki, T., Mizukami, S., Masui, T., Takahashi, H., 2001. Experimental investigation on general power of amorphous PV module for roof azimuth. Solar Energy Materials and Solar Cells 67, 369-377.

Yang, H., Marshall, R.H., Brinkworth, B.J., 1996. Validated simulation for thermal regulation of photovoltaic wall structures. In: Proceedings of the 25th IEEE PV Specialists Conference, Washington, DC, USA.

Yatsuki, S., Wada, K., Shimizu, T., Takagi, H., 2001. A novel AC photovoltaic module system based on the impedance-admittance conversion theory. In: IEEE 32nd Annual Power Electronics Specialists Conference, vol. 4. June. Vancouver, BC, pp. 2191-2196.

Yewdall, Z., Curtiss, P.S., Kreider, J.F., 2002. Photovoltaic and solar thermal market penetration analysis. In: International Solar Energy Conference, June 15-20, Reno, NV, USA, pp. 187-197.

Yohanis, Y.G., Mondol, J.D., Wright, A., Norton, B., 2008. Real-life energy use in the UK: How occupancy and dwelling characteristics affect domestic energy use. Energy and Buildings 40, 1053-1059.

Yoo, S., Lee, E., Lee, J., 1998. Building integrated photovoltaics: a Korean case study. Solar Energy 64 (4-6), 151-161.

Yordi, B., Gillett, W.B., 1997. Future trends in European PV power generation. Progress in Photovoltaics: Research and Applications 5, 175-185.

Yoshida, T., Tanda, M., Kato, S., Horigichi, M., Watanuki, Y., Hama, T., Ichikawa ,Y., Sakai, H., 1996. Roofing material integrated flexible a-Si PV modules.In: Conference Record of the IEEE Photovoltaic Specialists Conference, May 13-17, Washington, DC, USA, pp. 14331436.

Yoshino, M., Mori, T., Mori, M., Takahashi, M., Yoshida, S., Shirazawa. K., 1997. Development of photovoltaic modules integrated with a metal curtain wall. Solar Energy Materials and Solar Cells 47, 235242.

Yukawa, M., Kurokawa, K., 1994. Research and development of evaluation technology of photovoltaic power systems. Solar Energy Materials and Solar Cells 35, 453-459.

Yun, G.Y., Steemers, K., 2009. Implications of urban settings for the design of photovoltaic and conventional facades. Solar Energy 83, 6980.

Zacharopoulos, A., Eames, P.C., McLarnon, D., Norton, B., 2000. Linear dielectric non-imaging concentrating covers for $\mathrm{PV}$ integrated building façades. Solar Energy 68 (5), 439-452.

Zacharopoulos, A., 2001. Optical Design Modelling and Experimental Characterisation of Line-Axis Concentrators for Solar Photovoltaic and Thermal Applications. PhD Thesis, University of Ulster, UK.

Zastrow, A., Heidler, K., Sah, R.E., Wittwer, V., Goetzberger, A., 1981. On the conversion of solar radiation with fluorescent planar concentrators (FPCs). In: Proceedings of 3rd European Photovoltaic Solar Energy Conference, pp. 413-417.

Zrikem, Z., Bilgen, E., 1987. Theoretical study of a composite trombemichel solar collector system. Solar Energy 39, 409-419.

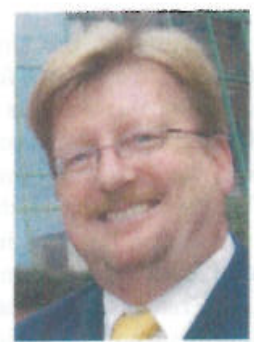

Professor Brian Norton is President of Dublin Institute of Technology, Ireland's largest higher education institution. Prior to this appointmen he had been Dean of Engineering and Built Environment at University of Ulster. Author or co-author of over 170 journal papers, he has supervised nearly forty doctorates and serves as Associate Editor of "Solar Energy" and on three other editorial boards. He has chaired national (in several countries) and international renewable energy bodies and been invited plenary speaker at numerous international conferences. He chairs Action Renewables. He has doctorates from Cranfield University and University of Nottingham. He is a Fellow of the Irish Academy of Engineering, the Energy Institute, the Institution of Engineers of Ireland and the Higher Education Academy. $\mathrm{He}$ is a Chartered Engineer (both in the UK and Ireland). Among his 
awards are the Napier Shaw Medal of the Chartered Institute of Building Services Engineers, the Roscoe Award of the Energy Institute and the Honorary Fellowship of the Chartered Institute of Building Services Engineers. He is an Honorary Professor of University of Ulster and of Harbin Institute of Technology, China. He is currently President of the Solar Energy Society of Ireland.

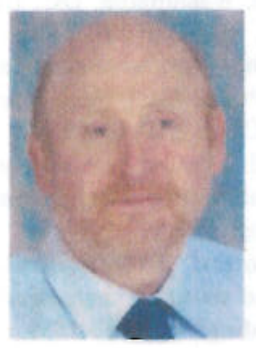

Professor Philip C. Eames is Professor of Renewable Energy and Director of the Centre for Renewable Energy Science and Technology at the University of Loughborough, UK. He was previously Director of the Warwick Institute for Sustainable Energy and Resources (WISER) where he held the Chair of Energy Efficiency and Conservation in the School of Engineering at the University of Warwick, UK. Before this he was Professor of Solar Energy Applications, directed the Centre for Sustainable Technologies and was Director of the Built Environment Research Institute within the School of the Built Environment at the University of Ulster. He has led research that has secured major advances in the dynamic simulation of the thermophysics of a very broad range of building facade components (particularly very-low heat loss glazings and building integrated photovoltaics), thermal energy storage systems and concentrating solar energy collectors. He has also developed new experimental performance characterisation techniques for building components. Professor Eames chairs the Solar Thermal Technical Panel for the World Renewable Energy Congress. He has a B.Sc., in Engineering Mathematics from University of Bristol and a M.Sc., in Energy Conservation and the Environment and PhD in Applied Energy from Cranfield University, UK.

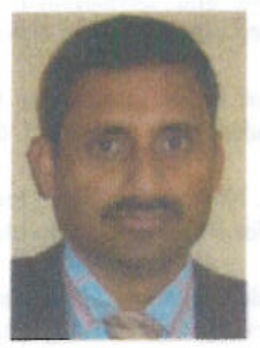

Dr. Tapas Kumar Mallick is a Lecturer in the Department of Mechanical Engineering at Heriott-Watt University, Edinburgh UK and Director of Studies of the M.Sc., in Renewable Energy. Previously he was Research Fellow at the School of Engineering, University of Warwick. He received his $\mathrm{PhD}$ in Solar Energy Engineering from University of Ulster, UK. He has worked Indian Institute of Technology, New Delhi, India, and University of Ulster, UK, for EPSRC, EU and DTI funding projects. His main research interests include optics, heat transfer, computational fluid dynamics and experimental characterisation of solar energy systems, low-cost solar photovoltaic concentrators, building integrated photovoltaics, concentrating photovoltaic/thermal integrated system, sustainable building components, and fuel cells. He has published over 25 papers. He is a member of the Institute of Physics and of the International Solar Energy Society.

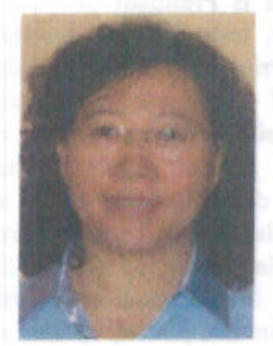

Dr. Ming Jun Huang is a Lecturer at the University of Ulster associated with the Centre for Sustainable Technologies. Before this she was a Lecturer in the School of Geography, Archaeology and Earth Resources at the Cornwall Campus of the University of Exeter. Previously she was Research Fellow at the Centre for Sustainable Technologies, School of Built Environment, University of Ulster, UK. Dr Huang received her $\mathrm{PhD}$ in Solar Energy Engineering from University of Ulster. Her main research interests include experimental and computational fluid mechanics and heat transfer in solar energy systems, buildings, building components and systems, thermal energy storage and heat pump application. She is a member of the International Solar Energy Society.

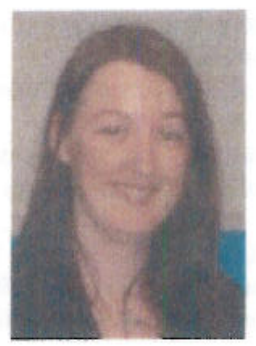

Dr. Sarah McCormack is a Lecturer in the Department of Civil, Structural and Environmental Engineering at Trinity College, University of Dublin, Ireland. Previously she was a senior researcher at the Dublin Energy Lab Dublin Institute of Technology. She graduated from University of Ulster with a $\mathrm{PhD}$ in a novel method for solar concentration using quantum dots collaborating with Imperial College London, Manchester University and BPSolar. After which she worked on EU projects based on evacuated glazing and phase change materials for energy storage. She is involved in a number of research projects including furthering the work on luminescent solar concentrators, combined PV and cellular antenna for building façade integration, investigation of issues relating to building integrated photovoltaic applications such as system optimisation and thermal control and feasibility studies of PV. She is also involved in a multidisciplinary national project on Energy Policy in Domestic Buildings and has recently been awarded funding for 'Solar Energy Applications and Research Centre' one of the first in Ireland. She is currently Secretary of the Solar Energy Society of Ireland and national representative of the EU PV Technology Platform Mirror Group.

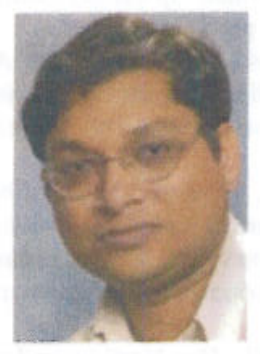

Dr. Jayanta Deb Mondol is a Lecturer in the School of the Built Environment, University of Ulster where previously he was Research Fellow. He completed his $\mathrm{PhD}$ in the field of 'BuildingIntegrated Photovoltaics' at University of Ulster. $\mathrm{He}$ received B.Sc. (Hons) and M.Sc. degrees in Physics from Visvabharati University, India. He has MTech degree in Energy Science and Technology from Jadavpur University, India. Previously he was Research Associate at the Centre for Sustainable Technologies at University of Ulster, where he was involved in a Household Energy Efficiency Study in Northern Ireland, a study of Innovative in Situ $\mathrm{CO}_{2}$ Capture Technology for Solid Fuel Gasification and Upgrading of High Moisture Low Rank Coal to Hydrogen and Methane. He is involved currently in renewable energy and sustainable development including Solar Thermal and Photovoltaic Systems and Vacuum Glazing. He has published over 20 papers.

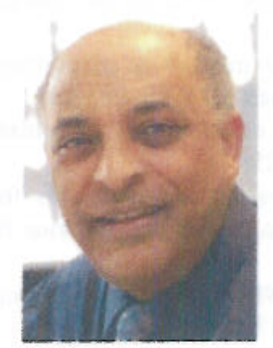

Professor Yigzaw G. Yohanis teaches and undertakes research in thermal systems engineering at University of Ulster. He served in industry in various senior positions as user and manufacturer of distributed diesel power systems, rural water supply and as manager of research and development. He is a member of University of Ulster's Built Environment Research Institute. His research interests include thermal modelling, building integrated photovoltaics, solar water pumping, solar thermal heating and cooling of buildings, long-term solar thermal storage and energy in buildings. He has published extensively in leading journals in the field of energy. He is a recipient of a Royal Academy of Engineering award, and is Visiting Professor at Darma Persada University in Jakarta, Indonesia. He has research collaborations in solar thermal, photovoltaics, energy storage, energy in buildings, household energy use and biomass include the Institute for High Temperatures, Russian Academy of Sciences, Moscow, Russia; University of Warmia and Mazury, Olsztyn, Poland; Bogor Agricultural University, Bogor, Indonesia; Oklahoma State University, USA; Northern Ireland Electricity; Imperative Energy, Maynooth, Ireland and Northern Ireland Housing Executive. He has been director of the Energy Design Advice Scheme for Northern Ireland; director of the Engineering Services Training Partnership and an Energy Consultant for the Building Research Establishment. 